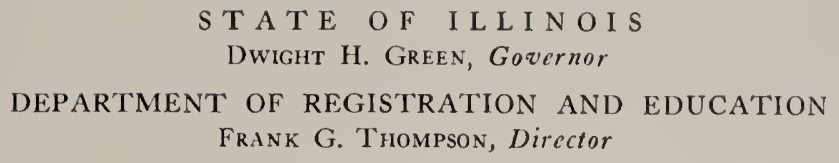

\title{
Survey of the Illinois Fur Resource
}

\author{
LOUIS G. B ROWN \\ LEE E. Y E A G E R
}


STA TE OF I LLINOIS

Dwight H. Green, Goqernor

DEPARTMENT OF REGISTRATION AND EDUCATION

Frank G. Thompson, Director

BOARD OF NATURAL, RESOURCES AND CONSERVATION

FrANK G. THOMPSON, Chairman

William Trelease, D.Sc., LL.D., Biology

Ezra J. Kraus, Ph.D., D.Sc., Forestry

I. R. Howsow, B.S.C.E., C.E., Engincering
Artiur Cutts Willard, D.Eng., LL.D.,

President of the University of Illinois

EDson S. BAstin, Ph.D., Geology

Roger AdAMs, Ph.D., D.Sc., Chemistry

\title{
NATURAL HISTORY SURVEY DIVISION Urbana, Illinois
}

\author{
Scientific and Technical StafF \\ Theodore H. Frison, Ph.D., Chief
}

Section of Economic Entomology

Wr. P. FliNt, B.S., Chief Entomologist

C. C. Compton, Ph.D., Associate Entomologist

M. D. Farrar, Ph.D., Research Entomologist

J. H. Bigger, M.S., Associate Entomologist

S. C. Chander, B.S., Southern Field Entomologist

James WV. APPLE, M.S., Northern Field Entomologist

B. G. Berger, M.A., Assistant Entomologist

H. B. PetTr;, JR., B.A., Assistant in Entomology Extension

C. J. Weinman, Ph.D., Special Research Assistant in Entomology

JoIIN M. WRIGHT, B.A., Junior Entomologist (U.S.B.E.P.Q. and Commodity Credit Corporation, cooperating)

\section{Section of Insect Survey}

H. H. Ross, Ph.D., Systematic Entomologist

Carl O. Mohr, Ph.D., Associate Entomologist, Artist (on leave)

B. D. Burks, Ph.D., Assistant Entomologist (on leave)

Milton W. Sanderson, Ph.D., Assistant Entomologist

Kathry M. Sommermax, M.S., Artist, Entomological Assistant

Section of Forestry

JAMES E. DAvis, M.F., Extension Forester

LeE E. Yeager, Ph.D., Forester
Section of Aquatic Biology

David H. Thompson, Ph.D., Zoologist

George W. BennetT, Ph.D., Limnologist

D. F. Hansen, Ph.D., Assistant Zoologist

Section of Game Research and Management

R. E. Yeatter, Ph.D., Game Specialist

Section of Wildlife Experimental Areas

ArThur S. Hawkins, M.S., Game Technician (on leave)

F. C. Bellrose, JR., B.S., Assistant Game Technician

J. B. Low, Ph.D., Assistant Game Technician

W. H. Elder, Ph.D., Assistant Game Technician

Cooperative Wildlife Restoration Program

(State Department of Conservation and $U$. $S$. Fish and Wildlife Service)

Otto W. TIemeier, M.A., Junior Biologist

Section of Applied Botany and Plant Pathology

L. R. Tehon, Ph.D., Botanist

D. B. Creager, Ph.D., Research Pathologist

J. C. Carter, Ph.D., Assistant Botanist

G. H. BoEwe, M.S., Field Botanist

Section of Publications

James S. Ayars, B.S., Technical Editor

Consultant: Herpetology, Howard K. Gloyd, Ph.D., Director of the Museum, Chicago Academy of Sciences

These papers are contributions from the Section of Forestry, the Cooperative Wildlife Restoration Program, and the Section of Insect Surtey. 
$\mathrm{T}$ HE two studies presented here, Survey of the Illinois Fur Resource and Illinois Furbearer Distribution and Income, represent sincere attempts to obtain by different methods a reasonably reliable measure of the valuable fur resource of Illinois. Each study has certain inherent strengths and weaknesses. The oral survey, basis for the Brown \& Yeager report, was intensive in its technique. The analysis of fur-takers' reports, basis for the Mohr report, was extensive. The Brown \& Yeager data represent but 1.7 per cent of the area of the state, but within the strips actually surveyed were included all trappers, licensed and unlicensed, those who reported catches and those who did not. The Mohr figures represent every county in the state but they are selective in that, of necessity, they take into account only those trappers who reported their catches; that is, 10 to 23 per cent of the total number of licensed trappers. The Brown \& Yeager data are based on oral answers given 15 days to over 14 months after the end of the trapping season covered by the questionnaire; no penalty for false answers was provided. The Mohr data are based on written answers given not later than the fifth day of the month next succeeding the month for which each report was made; persons making false answers could be prosecuted under the law. The Brown \& Yeager report covers two trapping seasons; the Mohr report covers eight.

As must he expected in reports based on sampling, particularly sampling in which the human element plays an important part, calculated figures in these two reports do not coincide. However, the figures do not vary abnormally and, in nearly every instance of identical subject matter, a close correlation or parallel relationship exists hetween the two sets of figures.

The closeness of the corresponding figures and the degree of correlation between the two sets of figures indicate that, despite the errors that may have resulted from small or faulty sampling and despite possible errors resulting from inexact memory of persons questioned, the two reports give for the Illinois fur resource a picture so nearly accurate that it can serve as a useful guide in many matters pertaining to the fur-bearing animals of the state.

The two reports agree in placing the value of the annual fur take of Illinois at over $\$ 1,000,000$, and they agree on the relative values of the various fur-bearing animals. The species that can profitably be fostered and those that cannot is clearly indicated by a study of the two reports.

The fur income of the state is still derived, as in pioneer years, from cropping a natural resource as it occurs in the wild, with very little conscious management by man. Much of the fur harvest is carried on by low income groups at a time of year in which other sources of income are scarce. Both of these facts should be considered in relation to the conservation or expansion of the Illinois fur industry and to the framing of laws regulating it.

The present reports are an outgrowth of earlier and less comprehensive studies by the Natural History Survey and its predecessors, some published (Wood 1910, Forbes 1912) and some not (Driver 1930, Rasmussen 1931). The fine cooperation of the State Department of Conservation, Springfield, Ill., has made possible the present more conclusive reports; for the Brown \& Yeager study, this department made available special research investigation funds administered in cooperation with the U. S. Fish and Wildlife Service under terms of the Federal Aid in Wildlife Restoration Act, commonly known as the Pittman-Robertson Act, and for the Mohr report it provided essential records and information. The Natural History Survey is most appreciative of this assistance.

Mr. James S. Ayars, Technical Editor of the Survey, has contributed much to the accurate presentation and unification of the data of the two separate manuscripts involved and their adaptation to the general Survey format. His services in this connection are appreciated by all concerned.

T. H. Frison, Chief

Illinois Natural History Survey 


\section{List of Illinois Mammals Discussed in Articles 6 and 7}

\section{CommoN NAME}

\author{
Scientific Name
}

Badger. . Taxidea taxus (Schreher)

Beaver. Castor canadensis Kuhl

*Black bear. Euarctos americanus (Pallas)

Bobcat, wildcat, bay $\operatorname{lynx} . \ldots \ldots \ldots \ldots \ldots \ldots L_{y} n x$ rufus (Schreber)

Coyote, brush wolf, prairie wolf. Canis latrans Say

Dog, wild $\operatorname{dog} \ldots \ldots \ldots \ldots \ldots \ldots \ldots \ldots \ldots \ldots \ldots \ldots \ldots \ldots$ Caniliaris Linnaeus

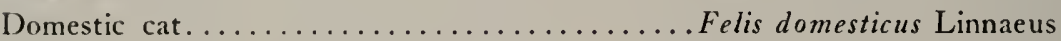

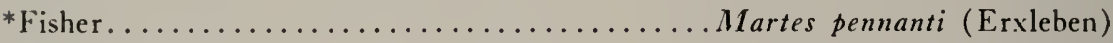

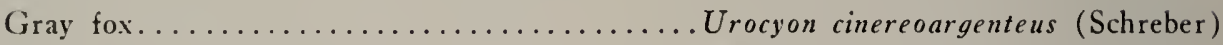

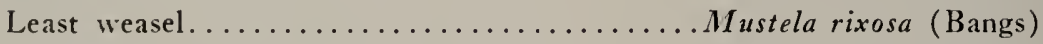

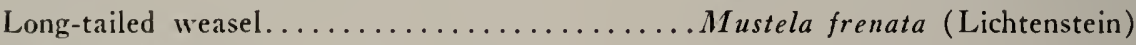

*Lynx, Canada lynx.................... Lyx canadensis Kerr

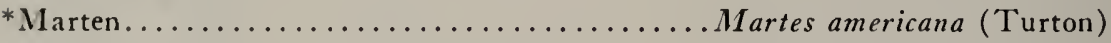

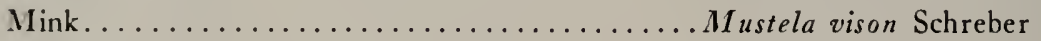

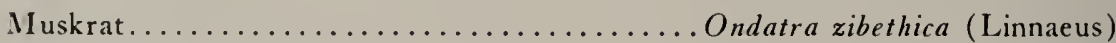

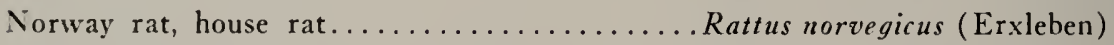

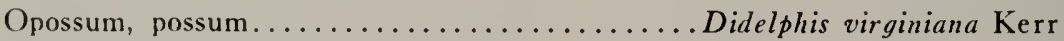

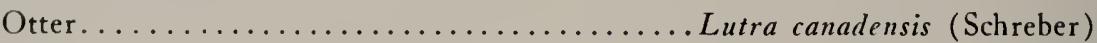

*Puma, panther, mountain lion.................. colis concolor True

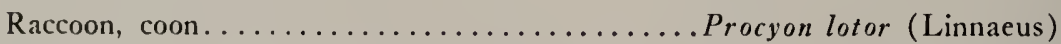

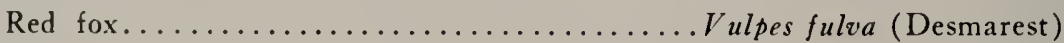

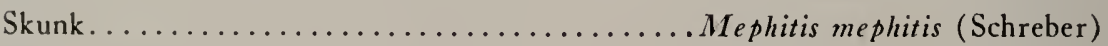

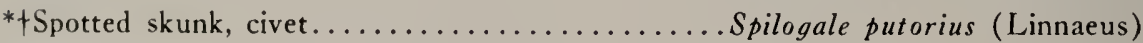

* Vut now present in Illinois.

†'ast occurrence in Illinois doubtful. 


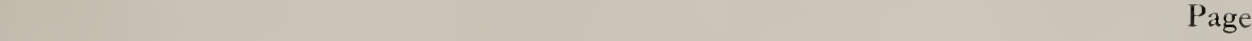

Project Administration..................................... 436

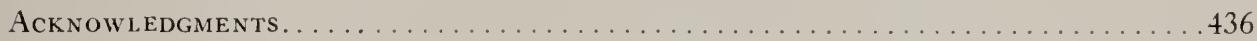

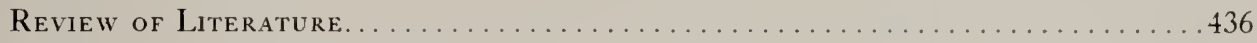

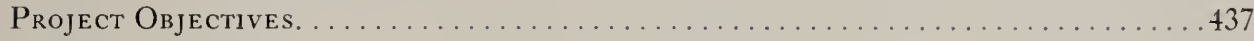

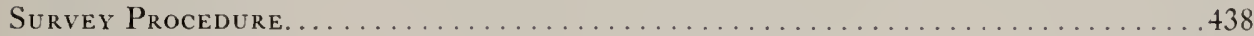

Fur Survey Regions... . . . . . . . . . . . . . . . . . . . . . . . . . . . . 439

Northwest Hills. . . . . . . . . . . . . . . . . . . . . . . . . . . . . . . . . . . . . . . . . . 439

Western Prairie.................................... 4 .

River Bluffs and Bottoms............................... 441

Northwestern Sand Prairie................................. 441

Glacial Lakes.................................... 443

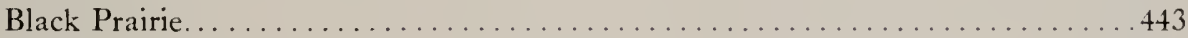

Central Sand Prairie....................................... 444

Gray Prairie. . . . . . . . . . . . . . . . . . . . . . . . . . . . . . . . . . 444

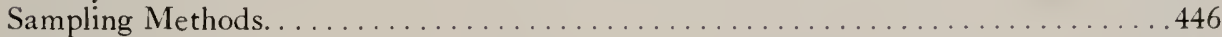

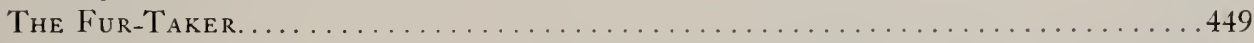

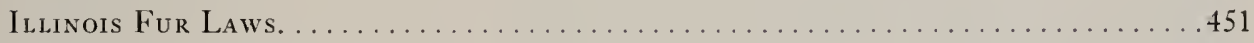

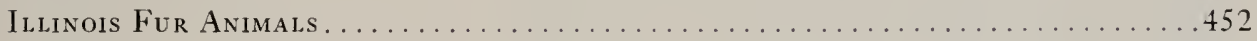

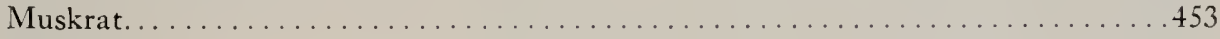

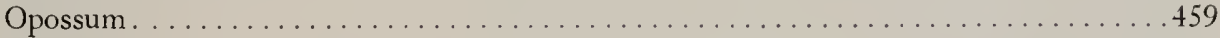

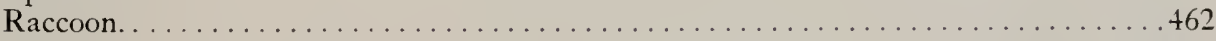

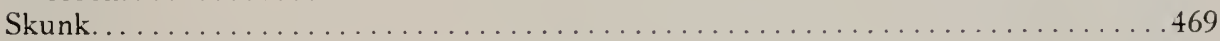

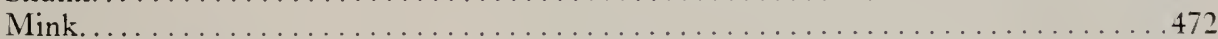

Long-Tailed Weasel. ........................................ 478

Red Fox. . . . . . . . . . . . . . . . . . . . . . . . . . . . . . 481

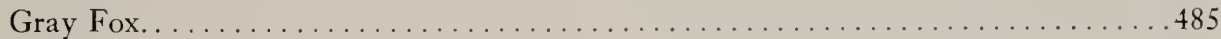

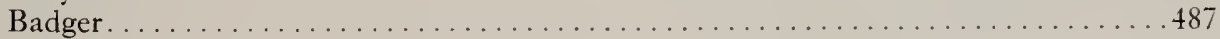

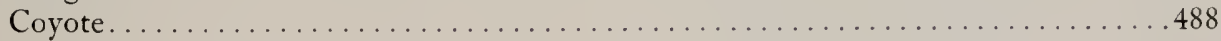

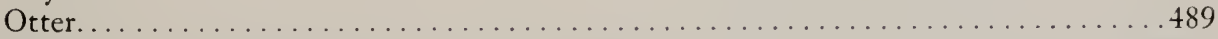

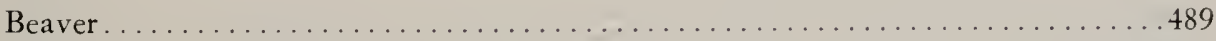

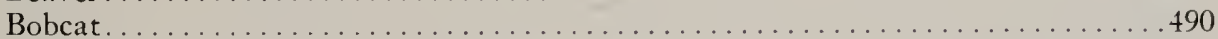

House Cat. . . . . . . . . . . . . . . . . . . . . . . . . . . . . . . . . .

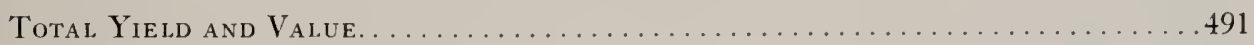

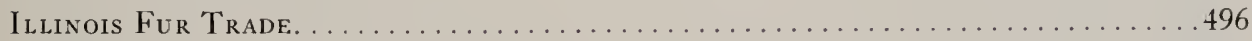

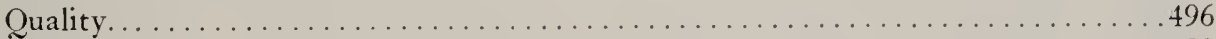

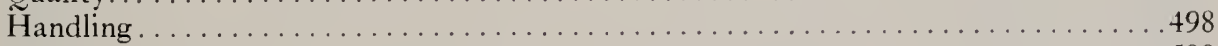

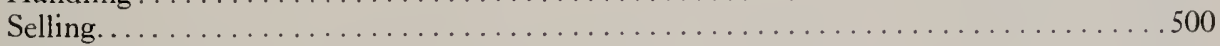

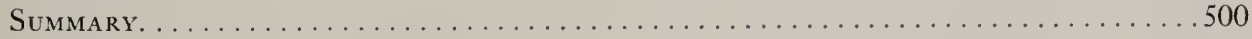

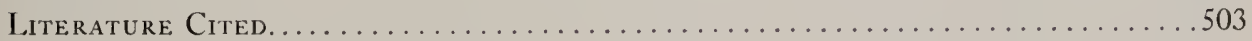



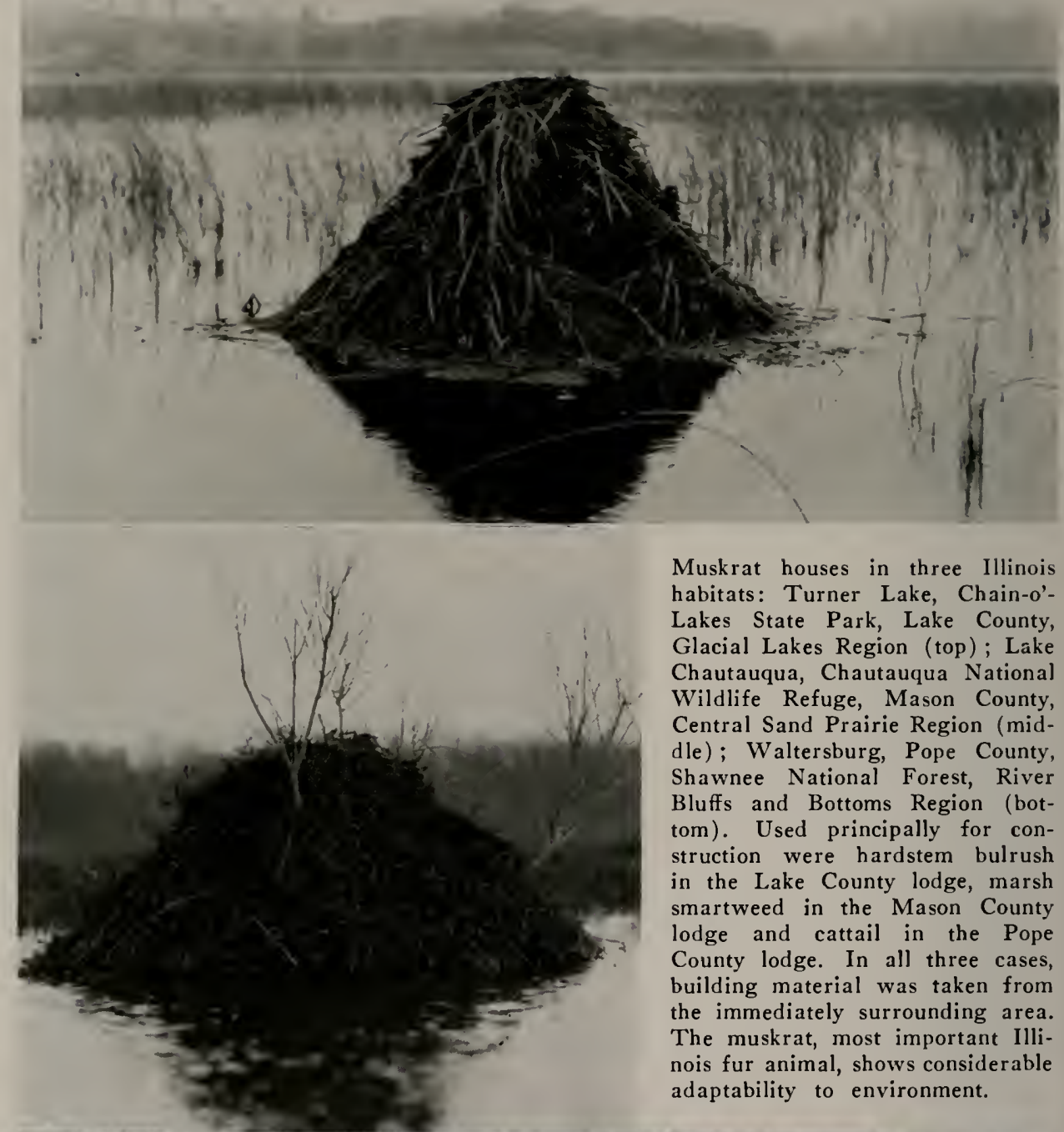

Muskrat houses in three Illinois habitats: Turner Lake, Chain-o'Lakes State Park, Lake County, Glacial Lakes Region (top); Lake Chautauqua, Chautauqua National Wildlife Refuge, Mason County, Central Sand Prairie Region (middle) ; Waltersburg, Pope County, Shawnee National Forest, River Bluffs and Bottoms Region (bottom). Used principally for construction were hardstem bulrush in the Lake County lodge, marsh smartweed in the Mason County lodge and cattail in the Pope County lodge. In all three cases, building material was taken from the immediately surrounding area. The muskrat, most important Illinois fur animal, shows considerable adaptability to environment.

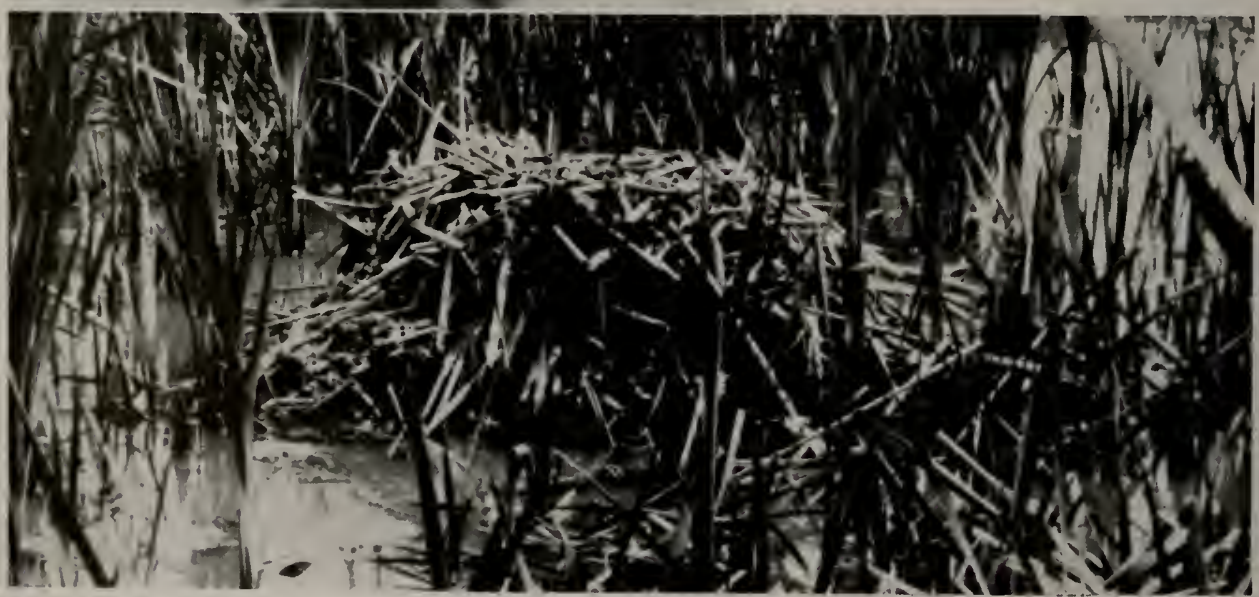




\section{Survey of the Illinois}

\section{Fur Resource*}

\section{LOUIS G. B ROW N LEE E. YEAGER}

$\mathrm{T}$ HE fur trade played an important part during the era of exploration and settlement in Illinois. Kaskaskia, the site of which is near Chester, Ill., and Cahokia, now a part of the St. Louis, Mo., metropolitan area, were important posts during the Revolutionary $W$ ar period, when considerable quantities of Illinois fur were transported down the Mississippi River to New Orleans. Because of its strategic central location and proximity to the more important water routes, Fort Dearborn, located where part of Chicago now stands, early in the nineteenth century became a leading fur center of the vast Great Lakes-Mississippi valley region. The Illinois River became and long remained the principal avenue of the fur trade in the state, and most of the traffic was consigned to Chicago, Detroit and other Great Lakes centers. By the close of the Civil War, St. Louis dominated the fur trade in the Central States, and from that time until the present this city has received a large portion of Illinois furs. Many Illinois cities, including Peoria, La Salle, Kankakee, Danville and Cairo, had their beginnings as local posts in the fur trade.

'The state's remarkably fertile soil and diversity in its prairie and forest types made for quality and variety in Illinois furs. Although the pelts of only a few fur species were important in the early trade, the Illinois fur animal fauna ranged from the lowly southern opossum to the valuable wilderness-inhabiting marten and fisher. The beaver, so important as to serve as a basis of exchange during the era of exploration in North America, did not occur in the same great abundance in the prairie state of Illinois as in the heavily forested regions farther north.

* Illinois Federal Aid Publication No. 3.
As settlement progressed in Illinois, most of the species intolerant of the changes effected by increasing human activities either retreated northward into the forests or were otherwise extirpated from the state; a few persisted in such small numbers that they are now of no commercial consideration. The long list of intolerant species includes the marten, fisher, timber wolf, panther, black bear, lynx, otter, beaver and bobcat. Of these, the marten and fisher were the first to go; the beaver has been reintroduced; and the otter and the bobcat may still occur in extremely limited numbers.

Common or farmland furbearers, such as muskrat, mink, raccoon, skunk, foxes, weasel and opossum, still persist throughout all or most of the state, though some in greatly reduced populations. The badger now has a very restricted range in Illinois, and the coyote, said to have been common during the buffalo or bison era, was later nearly exterminated, but is now reappearing in greater numbers. It is from the farmland species that the annual fur harvest has continued without interruption through the full duration of Illinois history. Despite all decimating factors, necessary and otherwise, affecting fur animals and their habitats, and despite the almost total lack of management, the Illinois fur resource returns an annual income of over $\$ 1,000,000$ to the people of the state.

Officials charged with the administration of Illinois wildlife have come to appreciate the actual and potential values of the state's wild fur animals. Through this interest, they proposed the project on which this report is based. Formally designated as Project 1-R, "Illinois Fur Animal Resources Survey," this project was the first Illinois unit of the Federal 
Aid in Wildlife Restoration Act program, and was approved by the Bureau of Biological Survey of the U. S. Department of Agriculture in May, 1939. The inrestigation was initiated on June 1, 1939, and completed on June 30, 1940.

\section{PROJECT ADMINISTRATION}

Supervision of Project $1-R$, which was of the survey type of research, was assigned to the Illinois Natural History Survey by the Illinois State Department of Conservation. Dr. 'T. H. Frison, Chief, representing the Natural History Survey, and Mr. Anton J. Tomasek, representing the Department of Conservation, directed the project from the fiscal and administrative standpoints. Dr. Carl O. Mohr and the junior author, both of the Natural History Survey, jointly supervised the field work; and all project papers, reports and technical details were handled directly or under the immediate supervison of the latter.

The senior author was selected as leader of the project and served in this capacity until its termination. He was responsible for the field survey, a summarization of data and a preliminary draft of the main body of the paper.

\section{ACKNOWLEDGMENTS}

The writers make grateful acknowledgment to the following for assistance.

The Fish and Wildlife Service of the U. S. Department of the Interior (during the first part of this study the Bureau of Biological Survey of the U. S. Department of Agriculture) gave many helpful suggestions and much encouragement, officially extended through Mr. Albert M. Day and Mr. M. O. Steen.

Several members of the Illinois Natural History Survey staff aided materially. Dr. David $H$. Thompson gave much assistance with sampling and statistical problems after having directed two previous studies, some data from which are included in the Mohr* report. Dr. Ralph E. Yeatter, Mr. Arthur S. Hawkins and Mr. Frank C. Bellrose, Jr., aided in various ways.

Illinois State Department of Conservation game inspectors gave the project

*Throughout this paper, the term Mohr report refers to "IHlinois Furbearer Distribution and Income," by Carl O.
Molir, published with this paper as Article 7. leader assistance which unquestionably increased the reliability of field data taken. The following were especially helpful: Sam Parr, Willis Spencer, Fred Ireland, IVilliam Pippin, Charles Dewis, Gene Fullenwider and Robert Graham.

Dr. R. S. Smith of the University of Illinois College of Agriculture and Agricultural Experiment Station was of great assistance in making the division of the state into fur survey regions. Mr. Douglas E. Wade, now of Dartmouth College, offered suggestions on field technique.

Dr. Herbert H. Ross, Dr. George W. Bennett, Dr. Carl O. Mohr, Mr. Robert E. Hesselschwerdt and Mr. James S. Ayars, members of the Illinois Natural History Survey Staff, took most of the habitat photographs. Dr. Charles F. Hottes, Professor of Plant Physiology, Emeritus, University of Illinois, kindly permitted use of the photograph represented by fig. 22 .

Several leading fur companies and many Illinois fur buyers supplied valuable information. The writers wish particularly to thank the F. C. Taylor Fur Company, Hill Bros. Fur Company and the Abraham Fur Company of St. Louis, Mo., and Sears, Roebuck and Company of Chicago, all of which receive a considerable volume of Illinois raw furs. Mr. V. E. Hazel of Sears, Roebuck and Company was especially cooperative.

Finally, the writers' thanks are due to a great many individual hunters, trappers and others whose interest and cooperation have contributed to the completeness of this report.

\section{REVIEW OF LITERATURE}

There is relatively little published information on Illinois fur species. Kennicott $(1857,1858,1859)$, in accounts of most fur animals of the state, including fisher and marten, gave early reports on the economics of these animals. He recognized the fur value and the rodent-destroying proclivities of fur animals, but for the most part his discussion is concerned with habits and predatory relationships. Cory (1912) supplied detailed accounts of the habits and known occurrence of Illinois mammals, but only a most general account of their economic importance. Forbes (1912) recognized that the fur resource 
was significant and cited for 1910 valuations of $\$ 6,000$ and $\$ 1+, 000$ for minks and muskrats, respectively. The writers believe these figures are too low, even for the year involved.

In addition to the list by Cory, several other state and local lists of Illinois mammals have appeared. The best known are by Kennicott (1855), Thomas (1861), Hahn (1907), IVood (1910), Sanborn (1925), Gregory (1936), Necker \& Hatfield (19+1) and Mohr (19+1). All except Hahn, Necker \& Hatfield and Mohr describe the habits of Illinois fur animals in more or less detail. Kennicott, Sanborn and Gregory deal only with the Chicago area. Wood's studies are limited to Champaign County, but his interesting chapter on mammal succession is applicable probably to a much wider region. Necker \& Hatfield and Mohr present the most recent information on the distribution of mammals throughout Illinois.

The economics of Illinois fur animals were not studied in the light of present conditions until Driver (1930) and Rasmussen (1931) compiled material on the yield and value of the fur resource for the Illinois Natural History Survey; some figures derived by these investigators were published in the Blue Book of the State of Illinois (Frison 1931, 1933). During the past few years, Mohr (1937, 1939) published information gathered from his study of Illinois trappers' reports. The Section of Fur Resources of the U. S. Department of Agriculture Bureau of Biological Survey (1939) and the U. S. Department of the Interior Fish and Wildlife Service (1940) published estimates of the total Illinois catch for several seasons which showed a range between 238,311 animals in the $193+-35$ season to 996,998 animals in the 1938-39 season. The material on which these figures are based was gathered from several sources, including the 11 linois State Department of Conservation and the Illinois Natural History Survey. The present study indicates that many of these figures are low.

\section{PROJECT OBJECTIVES}

Fur animals in Illinois, as in perhaps every other state, are of importance from viewpoints other than income. In one form or another there is nearly always the problem of predator control, which is brought up most frequently by farmers and sportsmen decrying real and alleged inroads of foxes, skunks and other carnivores on poultry and game birds. In Illinois, control is vigorously opposed by fox-hunting groups and to a lesser extent by central and southern orchardists, who appreciate the rodent- and insect-destroying habits of these animals. Sincere conservationists of certain convictions also oppose control. Illinois has little or no beaver damage, and no appreciable problem due to stock-killing coyotes. Wild dogs, sometimes reported as "wolves," are many times more destructive to domestic Illinois livestock than are coyotes. During recent years, members of coon-hunting* clubs, especially in the northern half of the state, have desired more sport and in some cases have supported movements designed to eliminate the raccoon from the trappers' list.

Perhaps the chief need for an impartial, fact-finding study lay in the necessity for providing reliable information on which to base theoretically sound, but still practical, fur laws. This need is particularly acute in Illinois due to the great northsouth length of the state and the consequent appreciable variations in the dates of fur priming. Because of these variations, the state has wisely been divided into three zones, namely, northern, central and southern, fig. 1 .

In the past, various regulations have marked the Illinois trapping season. The chief variations involve either staggered opening and closing dates for the three zones, staggered opening and closing dates for two or more important fur species, or both. The practice generally followed, that of staggering opening and closing dates for zones, is basically sound, the chief objection to it being the increased opportunity for some trappers to work southward through the three zones, taking a disproportionate share of the fur crop. The second variation-staggered opening and closing dates for species-induces a situation with which trappers, even those who most desire to be law abiding, cannot cope. In laws of this type, the muskrat season, because of the well-known delayed

\footnotetext{
* In this paper and the Mohr report, the words, coon and possum are sometimes used for raccoon and opossum. respectively. Buth popular and literary usage seems to sinction the abbreviated forms of these words.
} 
priming phenomenon characteristic of the species, is often postponed 15 to 30 days after the opening of the seatson on other animals. It likewise often extends the same length of time beyond the close of the season on other animals. In theory, the plan is good, and such a season will result in the taking of a larger percentage of more nearly prime muskrat furs. The imprac-

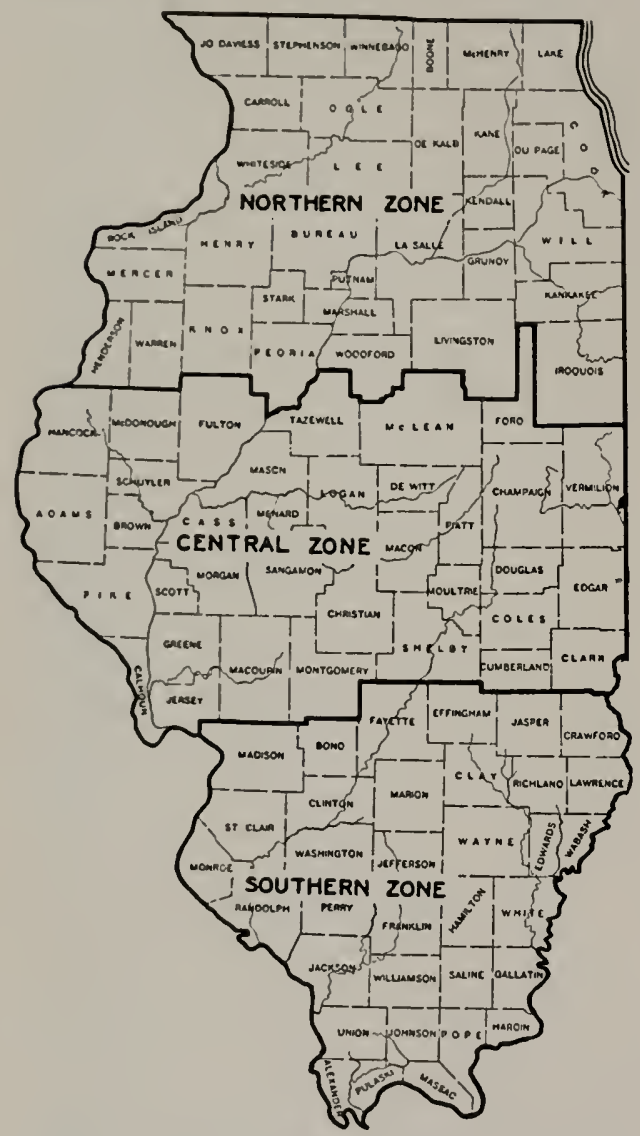

Fig. 1.-Map of Illinois showing the three zones applicable to the game and fish codes of the state.

tical application comes from the impossibility of keeping muskrats out of mink sets during the first part of the season and minks out of muskrat sets during the last part of the season. Many minks and muskrats are drowned after heing caught, and drowning is one of the best of all trapping techniques since it largely eliminates the escape of captured animals and is desirable from the humane standpoint. When animals are unavoidably taken illeg- ally during staggered seasons, trappers are faced with the unfortunate alternatives of destroying or pelting valuable furs. Even if such animals are not drowned, and later escape or are released, they may die of injuries or, in the event of recovery, be in a condition too poor to breed.

Prior to the initiation of project $1-R$, it was known that certain fur species in Illinois, especially raccoons, were reaching low population levels in many localities. In view of this situation, there was agitation for a completely closed season, a reduced season, bag limits, elimination of all raccoon trapping and various other measures, received mainly from sincere and well-meaning groups or individuals. In the absence of reliable and scientific information, it was impossible to act with full intelligence on these suggestions or to set fur trapping and hunting seasons fair both to the resource and to the appreciable number of people partly supported by it.

The general objectives of the survey; restated from the Preliminary Project Statement for $1-R$, included information on the following points as they pertained to Illinois:

1. Annual yield of pelts by species.

2. Annual income of fur-takers from the fur resource.

3. Methods of trapping, hunting and marketing furs.

4. Percentage of furs taken by trappers and hunters, respectively.

5. Number of unlicensed fur-takers.

6. Fur animal cycles.

Information derived was to serve as a basis for recommending sound fur animal laws and offering suggestions for practical fur animal management.

\section{SURVEY PROCEDURE}

In the attainment of the fur survey's objectives, limitations of time and personnel necessarily affected procedure. Only one full-time man for a 13-month period was available for the work. Since it was desired to include the entire state in the survey, full coverage, even of sample counties, was precluded. It became necessary, therefore, to devise a sampling procedure that permitted rapid coverage, yet one yielding reliable data of a quantitative nature. This involved two general steps: the division of the state into fur survey 
regions, and the separate sampling of each regional area.

\section{Fur Survey Regions}

A number of factors, rather than soil alone, were used as criteria in dividing Illinois into regions suitable to the purposes of this survey. These criteria, in lift, fig. 3. The northwestern corner is also unglaciated and is somewhat broken and rolling. The erosional effects of the Mississippi River on the west, the Ohio and Wabash rivers on the south and east, and the Illinois River, extending southwesterly from Chicago nearly to St. Louis, lower the prairie status of the state and make for an appreciable area of river bot-

Table 1.-Fur survey regions and data on field samples used in Illinois fur animal survey, 1938-39 and 1939-40.

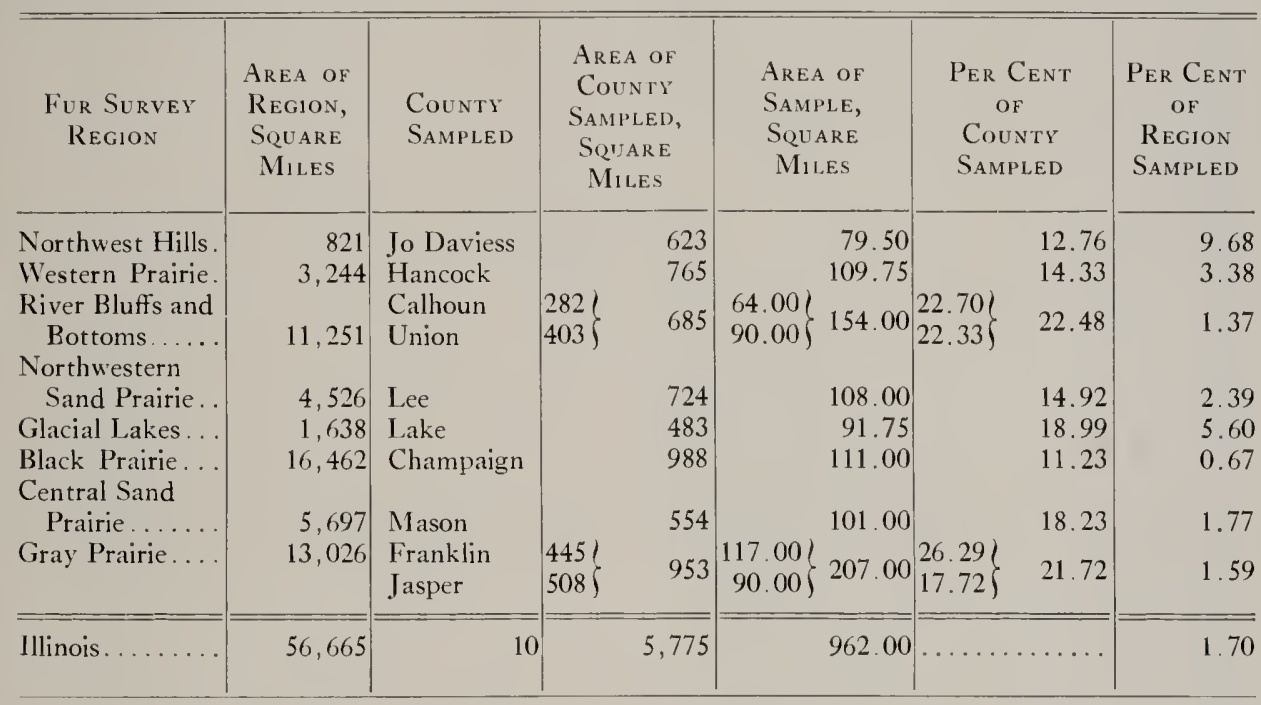

their order of importance, were as follows: (1) soil, (2) forest cover, (3) drainage, (4) topography, (5) fur animal distribution, (6) agricultural use and (7) latitude.

On the basis of the above criteria, the state was divided into the eight regions listed in table 1 and shown in fig. 2. For purposes of accurate area calculation, the dividing lines between all regions were run north-south or east-west, and therefore only approximate the true boundaries. The area of each region is given in table 1 . Various soil, drainage, topographic and cover maps were studied as an aid in defining the boundaries of areas over which uniform fur yields might be expected, figs. 3 and $t$.

Although recognized as a prairie state, Illinois is more or less diversified in soil, climate, topography and agriculture. The southern one-third is relatively rough and hilly, climaxed geologically by the eastern extension of the unglaciated Ozarkian up- toms and bluffs. Three definite sand areas and several larger sandy-soil regions further diversify the soil types of the state.

Illinois has a total area of 56,665 square miles, of which 622 are inland waters. The state ranks twenty-third in area and third in population. Seventy-five per cent of its boundary is water. Its length from north to south is 385 miles; its greatest east-west width is about 215 miles. For effect of latitude see "Project Objectives."

Physiographical features of Illinois were determined largely during the glacial epoch. The moraines throughout the northern half, the numerous kettle lakes in the Chicago region, the till and loess deposits, and the prairies are directly related to glacial advances and retreats. A brief description of the eight fur survey regions follows.

Northwest Hills.-This, one of the state's two unglaciated areas, is locally termed the "Little Switzerland of Illinois." It is very small, the fur survey 
region for this area measuring only 821 boundary along the Mississippi River is of square miles, fig. 2. The terrain is rolling rugged limestone bluffs. 'The thick limeto broken, figs. 5 and 25 . 'The western stone formation here has impeded the de-

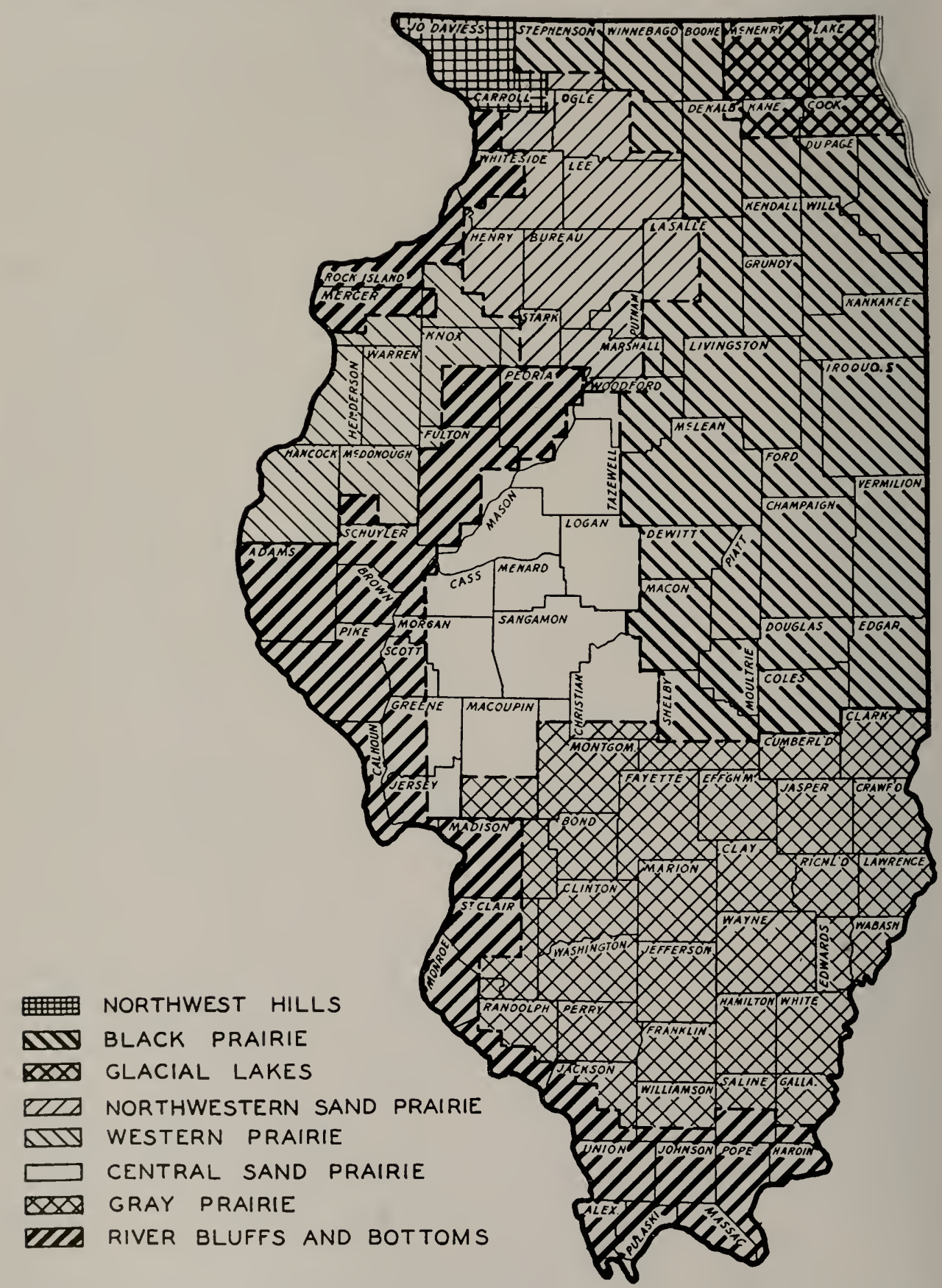

Fig. 2.-Map of Illinois showing the eight regions into which the state was divided for the purpose of making the fur resource survey. The River Bluffs and Bottoms Region is the only one that is not continuous. 
velopment of extensive bottomlands. Scattered throughout are wooded limestone outcrops, frequently surrounded by bluegrass slopes. Although overgrazing is common, pasture management is fair in many instances. Cultivation is limited. Comparatively well vegetated soils release their waters slowly, giving rise to numerous small, clear streams. Deforestation has progressed somewhat less rapidly here than in most other places in lllinois, making for relatively good wildlife cover over much of the region.

Western Prairie.- This is a fertile, rather low prairic area of $3,24+$ square miles, fig. 2. The western border is the Mississippi River, along which there is local development of bluffs and bottomland. Here, the prairie seemingly flows into the river at many points. Streams are small, and enough of them are intermittent to impair the quality of otherwise good muskrat and mink habitats. Woody cover is generally lacking.

River Bluffs and Bottoms.-As a fur animal habitat this survey region, the only one not continuous, is perhaps the most interesting in the state, fig. 2. It contains 11,251 square miles, being exceeded in size only by the black prairie and gray prairie areas. This region, figs. $6,18,22,24,26,27,28,29$ and 30 , determined largely on the bases of drainage and topography, contains three main subtypes characterized, respectively, by (1) three large rivers, all fluctuating in nature; (2) broken slopes or bluffs, which may be forested or partly cleared, and often pastured, leading down to bottomland; and (3) bottomland, timbered or cleared, often pastured and, in addition, often leveed. In all cases the bluffs are of limestone in varying stages of exposure and weathering. 'The region extends nearly the full north-south length of the state along the Mississippi River and through a number of counties along the southern half of the Illinois River. The heaviest population of raccoons, opossums and gray foxes in the state occurs in this region, as would be expected in a forested area. This large region, as a whole, shows a comparatively low muskrat yield, although some of the better muskrat marshes in the state occur along the middle Illinois River. Deforestation, leveeing, turbid and polluted water, and severely fluctuating water levels tend to impair the quality of the river bluffs and bottoms for fur animal occupancy.

Northwestern Sand Prairie.-This region is a rolling sand prairie, rather well interspersed with marsh, fig. 2. The

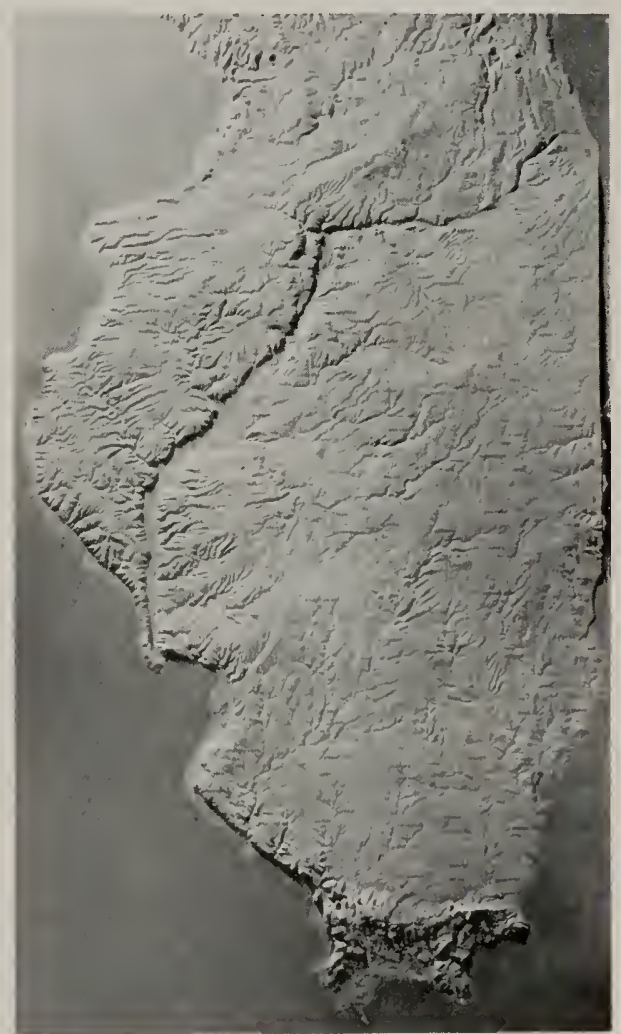

Fig. 3.-Relief map of Illinois showing main physical features of the state. (Print courtesy of the Illinois State Geological Survey.)

area is 4,526 square miles. Numerous small rivers, creeks and drainage ditches, many of which run the year around, add to the quality of the aquatic habitat. Lack of uniformity in physical features characterizes the region; areas of fertile black soil, limestone outcrops, marsh and sand ridges are the most common formations. The irregularity is due to deposits left by different periods of glaciation, and to sheet wash from melting ice masses. Sizable woodlands, chiefly of scrubby oak, supply some cover for raccoons. The Rock River, the largest stream within the northwestern part of the state, flows through the region. The valley of this river and that of the Green River are the main 


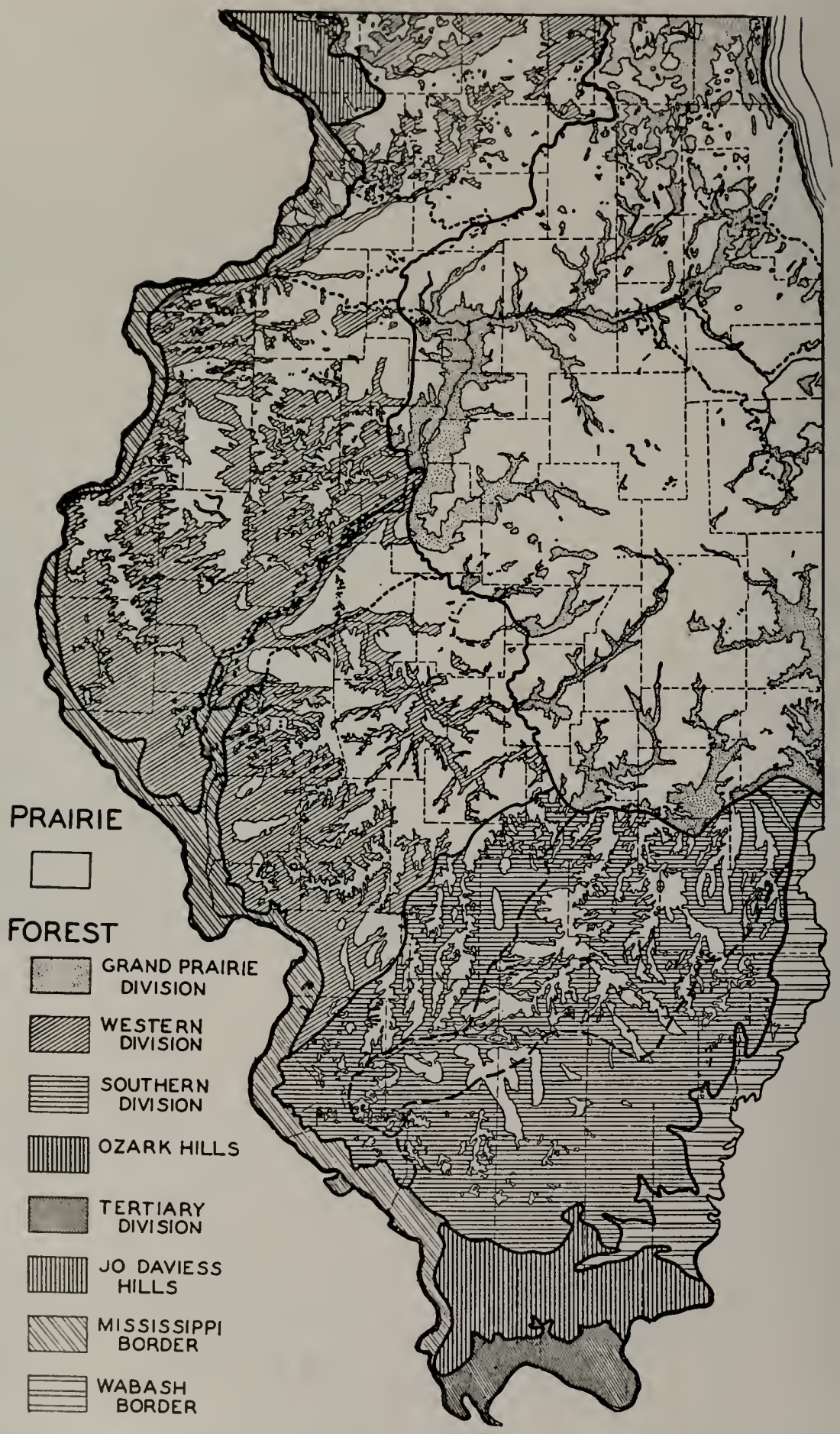

Fig. 4.-Vegetation map of Illinois. The shading, as shown in the key, indicates approximately the areas that were in forest early in the nineteenth century. (After map by Vestal 1931, based on map by Telford 1926.) 


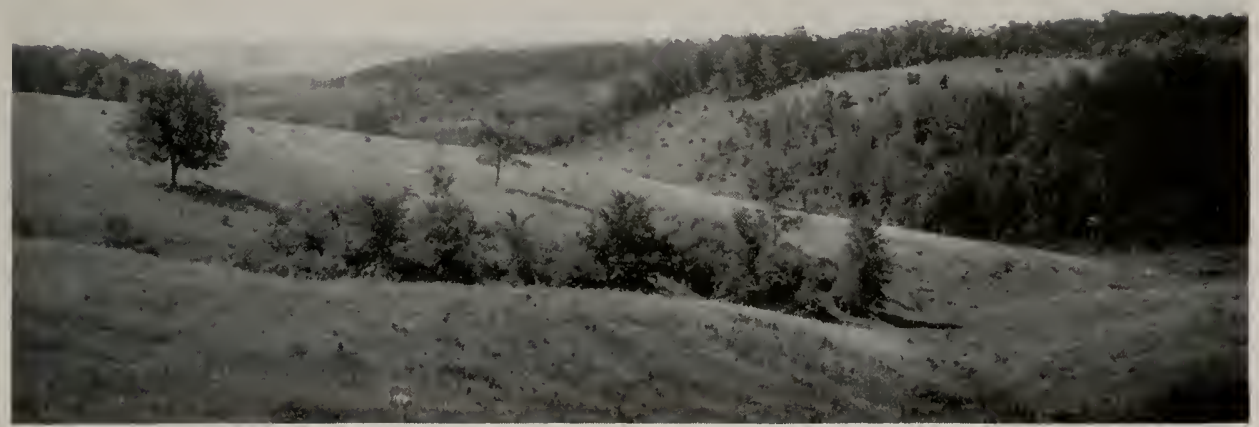

Fig. 5.-Northwest Hills habitat type. Forested hills, rolling terrain, permanent streams and absence of intensive agriculture make this region well adapted to skunks, gray foxes and badgers. A scene from Jo Daviess County is pictured here.

agricultural areas and in them are located most of the drainage ditches of the region.

Glacial Lakes.-In size, this is the second smallest of the eight survey regions, fig. 2. It contains only 1,638 square miles. Small glacial or kettle lakes are scattered rather uniformly over the entire area. Extensive cattail and bulrush marshes adjoin many of these lakes, forming excellent muskrat habitat, figs. 7 and 21. Varying amounts of emergent and floating vegetation in the lakes supplement the food supply. Water levels approach stability. The winters are usually severe. The topography is nearly level to rolling, and the soil is a heavy sandy loam. IVoodland found in the region is mainly on estates; farmer-owned woodland is largely pastured.

Black Prairie.-The well-known Illinois black prairie is the most extensive general soil type in the state, fig. 2 . The fur survey region set up for this soil type is $16,+62$ square miles in area. Streams, valleys and occasional moraines are the only deviations from its slightly rolling contour. Drainage ditches, fig. 8 , and tile lines occur throughout the region, and most of the water from them enters the Illinois River system.

The ditches and some of the streams afford fair to good muskrat and mink

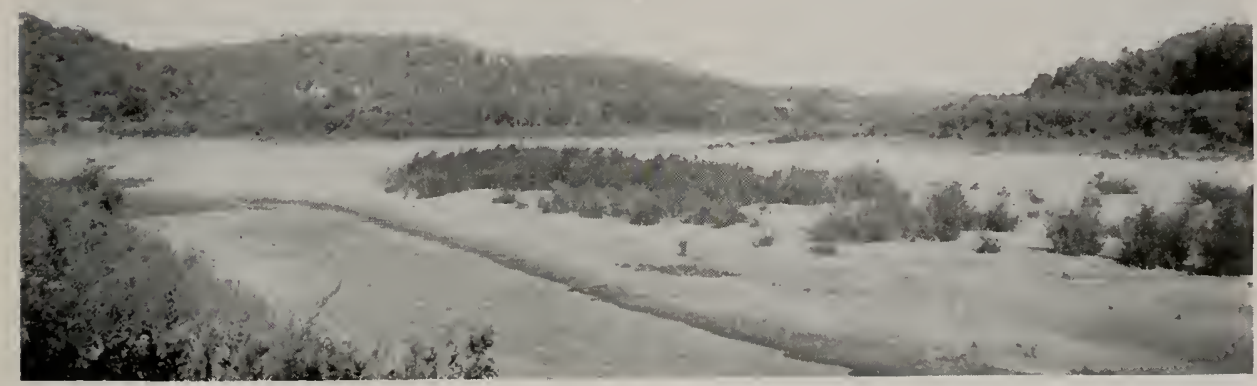

Fig. 6.-River Bluffs and Bottoms habitat type. Forest-inhabiting species such as raccoons, opossums and gray foxes occur in greater density here than in any other region in Illinois. The combination of aquatic and forest areas makes this region ideal raccoon range. Shown here is one of several connecting channels between the Illinois and Mississippi rivers, near Grafton. 


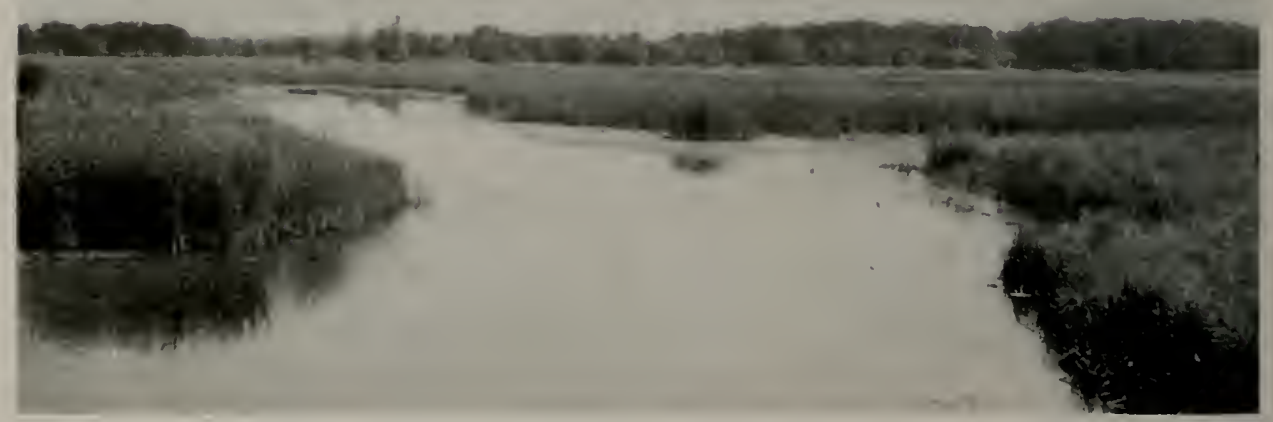

Fig. 7.-The Glacial Lakes Region, which is characterized by abundant vegetation and extensive areas of shallow water, furnishes excellent muskrat range. Muskrat houses are built in shallower water than that shown in the photograph.

habitats. The original marsh has virtually disappeared, and most of the bottomland timber has been cut or so depleted of den trees as to afford little raccoon cover. Stripmines are fairly common on the black prairie. Muskrats and minks are the chief species benefited by the new biological habitat created by the stripping process in mining coal.

Central Sand Prairie.-With the exception that it has more upland sand deposits, fig. 9, this region, fig. 2, is very similar to the Northwestern Sand Prairie. It contains numerous hardwood timber stands on the sand knolls, which afford some cover for forest fur animals. The whole region is somewhat more rolling and is cut by more small stream valley's than the Northwestern Sand Prairie. The lower Sangamon River valley merges into the Illinois River bottoms characterized at this point by sizable areas of low, welltimbered land. The area is 5,697 square miles. Mixed farming, grazing and cattle feeding constitute its main agricultural activities.

Gray Prairie.-This southern Illinois type constitutes the second largest fur survey region, 13,026 square miles in area, fig. 2. The gray color of the soil, chiefly

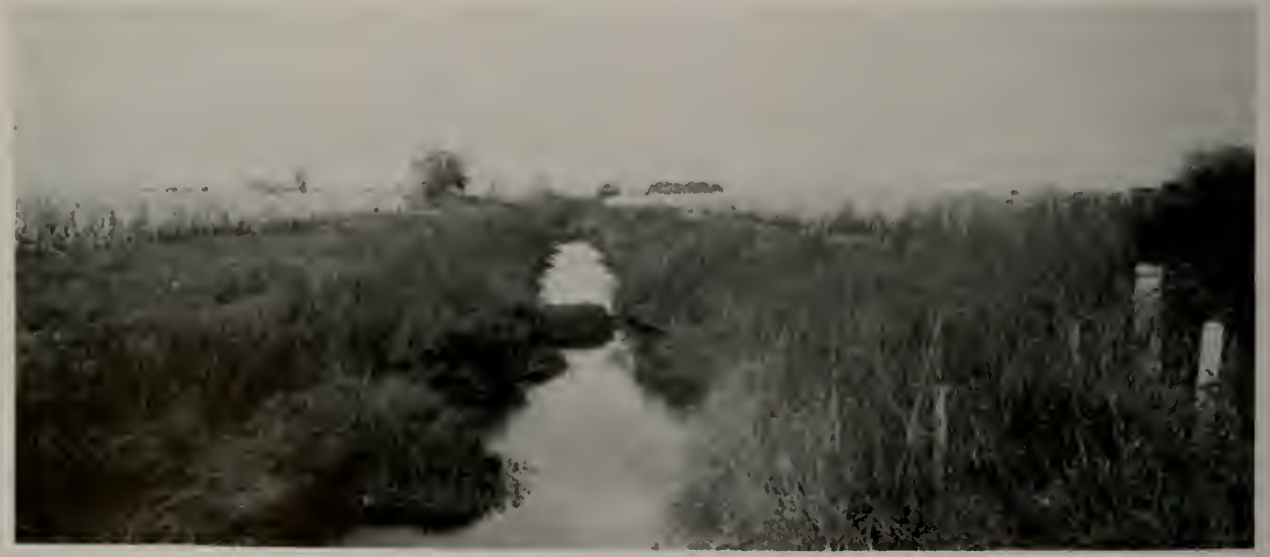

Fig. 8.-Black Prairie habitat type. Thousands of miles of ditches and ditchlike streams bordered by corn fields make for high muskrat yields in the Black Prairie Region. 


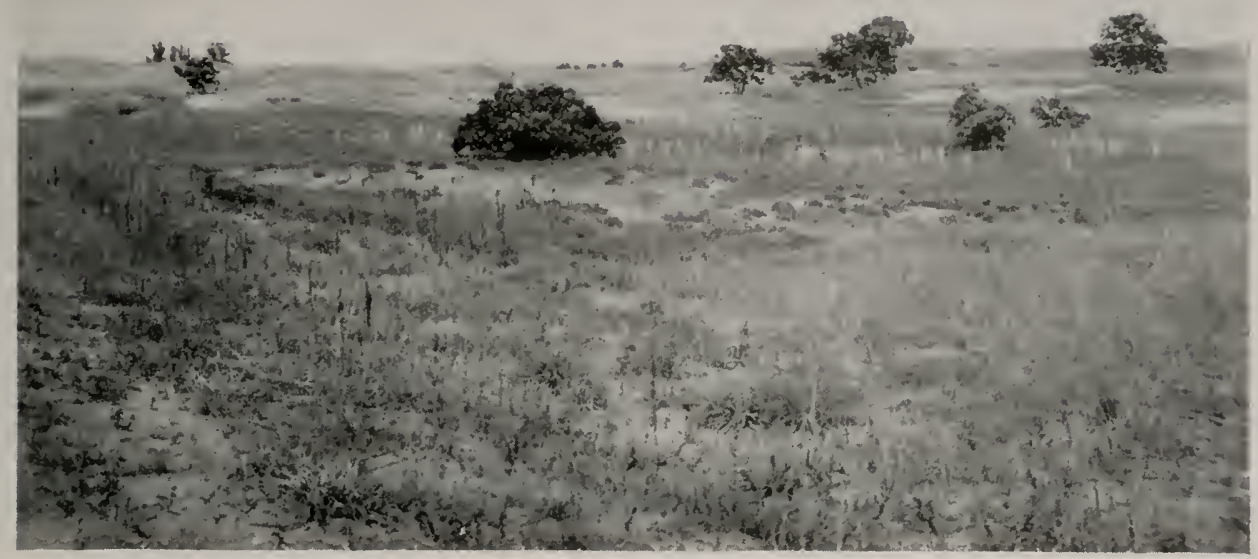

Fig. 9.-Sand Prairie habitat type, typical of several small regions in northern Illinois. Relatively unproductive soil and a general scarcity of marshes and streams account for the low fur yield for most species in the Central Sand Prairie Region.

loams and clays, suggests the name. Many of the larger and most of the smaller streams are intermittent. Rapid runoff, due to extensive clearing, a rolling topography and tight gumbo subsoils, is largely responsible for this condition. The larg- est river in the region, the Embarrass, ivas reduced to water holes during the fall of 1940. Much of the land is too poor for profitable farming, and a percentage unusual in Illinois has reverted to uncultivated fields and brushland, fig. 10. As

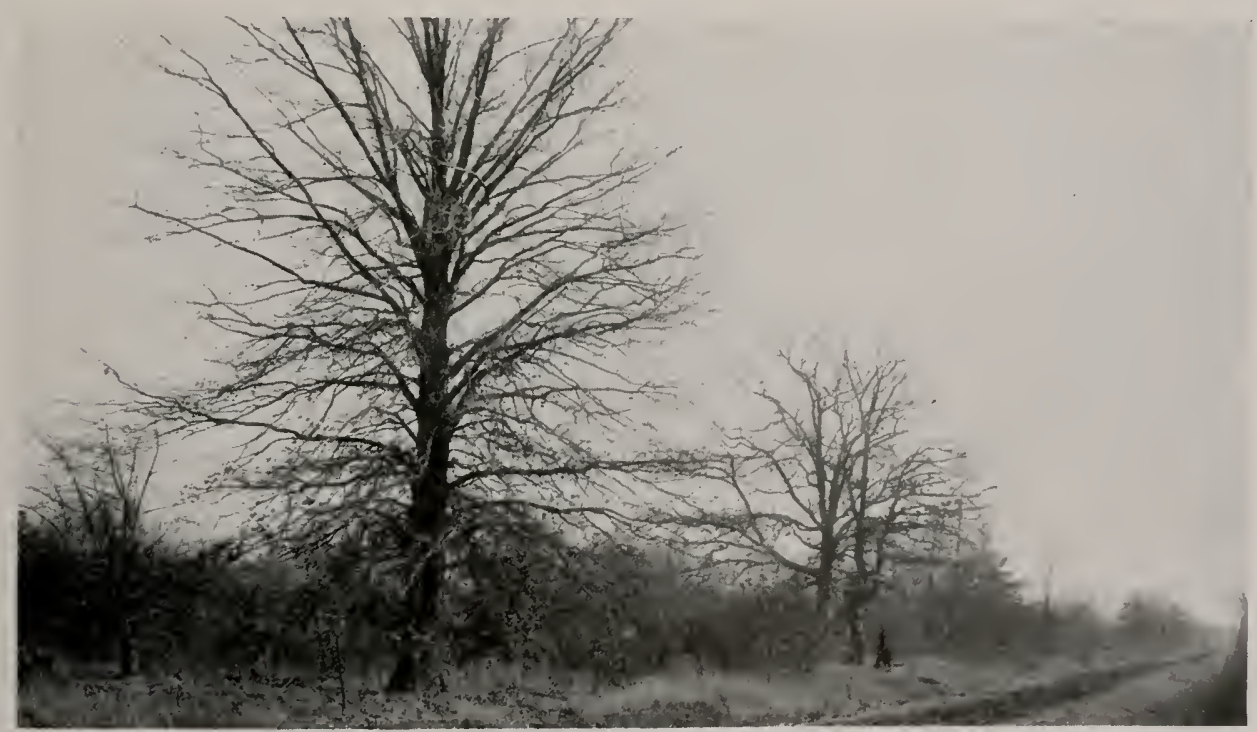

Fig. 10.-Gray Prairie habitat type. Characterized by good upland cover but a poor water supply, this type is comparatively low in fur production. Extensive woodland and non-intensive agriculture here favor most fur animals, but only a few permanent streams offer satisfactory range to such species as raccoons, minks and muskrats. 
a result, the region affords considerable upland game cover, hut the limited and undependable water supply greatly impairs the aquatic habitat. During recent years the Gray Prairie region has been exploited for coal, and at present it is being appreciably disturbed by an oil boom. Mine and oil residues are polluting some of the streams. Woodlots and larger timbered areas are scattered throughout the region.

\section{Sampling Methods}

For each of the fur survey regions one or two typical counties were selected as samples. In all, 10 sample counties were surveyed, fig. 11. The River Bluffs and Bottoms and the Gray Prairie regions were represented by two counties each. Across each county from three to nine strips, each 1 mile wide, were laid out in

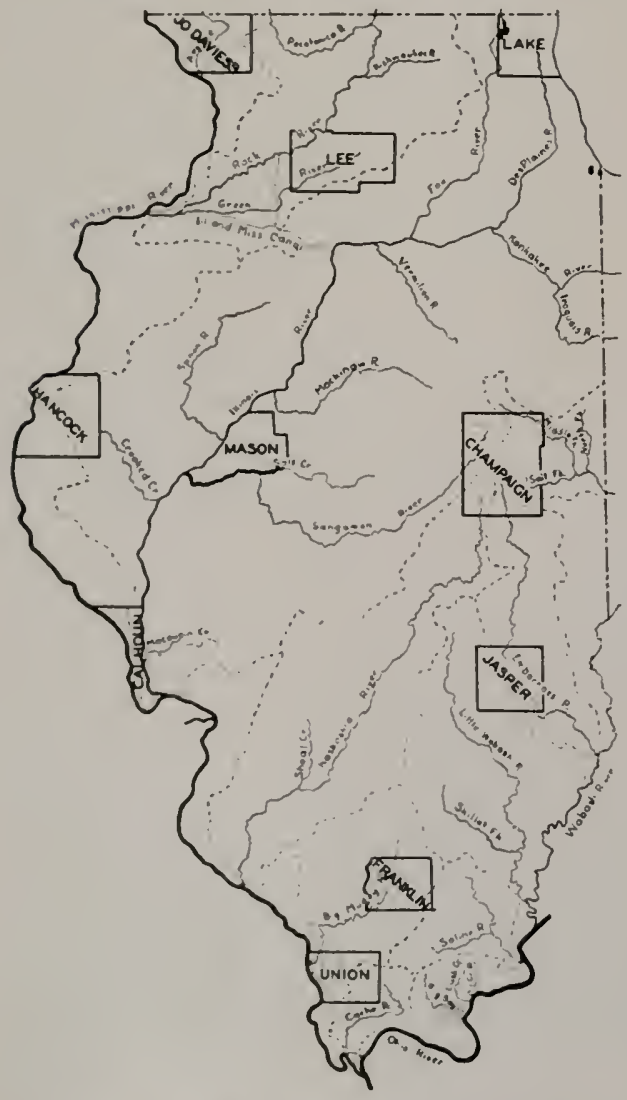

Fig. 11.-Map showing the counties sampled in the Illinois fur resource survey. Shown also are the main rivers and watersheds and divides (broken lines). an east-west direction, and every household in this area was canvassed in gathering the sample data, fig. 12. From 11.23 to 22.48 per cent of the counties made

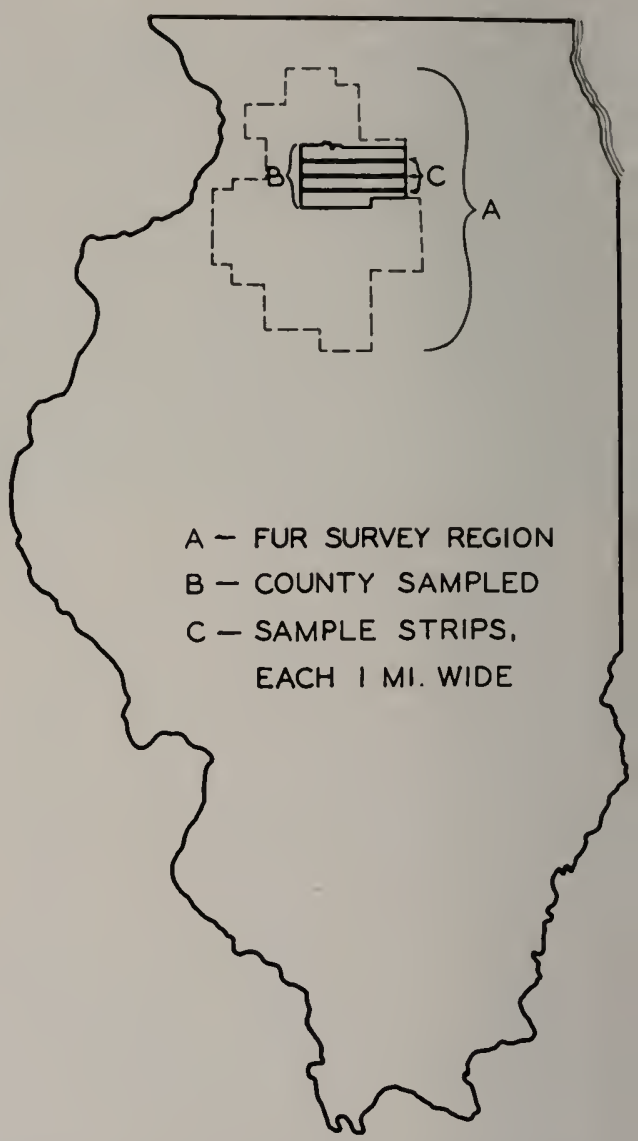

Fig. 12.-Map showing the relation of three sample strips and county to fur survey region. The position of Lee County is outlined.

up these samples, representing from 0.67 to 9.68 per cent of the total area of the regions and 1.70 per cent of the total area of the state. These data are given in detail in table 1.

The east-west direction of the strips tended to strike the streams at right angles, thus eliminating the error that would have resulted from following a stream or valley, comparatively productive of furs, for a long distance. In every case the strips extended the full east-west dimension of the county and insofar as physically possible were straight. County road maps were used to good advantage in establishing the strips and in locating residences or in re- 
cording certain pertinent data. The number of strips per county was governed by its north-south dimension and the number of crossings required to give at least a 10 per cent sample. Except in Jo Daviess and Hancock counties, in which data for both years were obtained simultaneously in the spring of 1940 , each strip was covered twice, once for the 1938-39 and once for the 1939-40 season.

As stated, every household covered by the strips was contacted, and with very few exceptions every resident admitting the taking of furs, or suspected of taking furs, was interviewed, and a record of his catch taken for both years of the survey.

ILLINOIS FUR ANIMAL RESOURCE SURVEY

FA-Illinols, Project 3-D

Individual Report

Season of

County
Location_ No.
Urban Rural

Name

Main occupation

Age__ Address

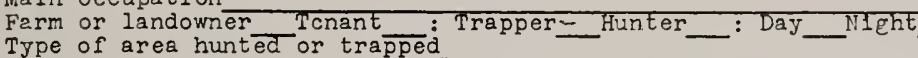

Approximate length of trapline miles. Average no. traps used

License: Fur tunting

form Trapper monthly form Hunter annual form Didn't report

Furs sold out of state In state Locally To T_ L L L

object in taking, fur: hunting __ Trapping_ Total Income

Record of Catch for $1938-39$

\begin{tabular}{|c|c|c|c|c|c|c|c|c|c|c|c|c|c|c|c|c|c|}
\hline & \begin{tabular}{c|c}
0 & 0 \\
5 & 0 \\
0 & 0 \\
0 & 0 \\
-1 & -1 \\
\end{tabular} & 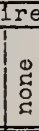 & $\begin{array}{r}\text { Furs } \\
\text { Trap- } \\
\text { p1ng }\end{array}$ & $\begin{array}{l}\text { take } \\
\text { Hunt } \\
\text { Day }\end{array}$ & $\begin{array}{l}\frac{a n b y}{2} \\
\text { Nins } \\
\text { Nite }\end{array}$ & $\frac{\text { No }}{1}$ & 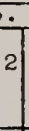 & $\mathrm{ta}$ & ke & 5 & by & $\bar{w}$ & $\overline{\mathrm{ek}}$ & $\begin{array}{l}\text { No. } \\
\text { dogs } \\
\text { used }\end{array}$ & $\begin{array}{l}\text { Fluc- } \\
\text { tua - } \\
\text { tion }\end{array}$ & $\begin{array}{c}\text { Total } \\
\text { no. } \\
\text { pelts }\end{array}$ & 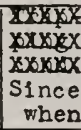 \\
\hline Muskrat & & & & & & & & & & & & & & & & & \\
\hline possum & & & & & & & & & & & & & & & & & \\
\hline $\begin{array}{l}\text { Raccoon } \\
\text { Slcunk }\end{array}$ & & & & & & & & & & & & & & & & & \\
\hline MInk & & & & & & & & & & & & & & & & & \\
\hline Red fox & & & & & & & & & & & & & & & & & \\
\hline Gray fox & & & & & & & & & & & & & & & & & \\
\hline Weasel & & & & & & & & & & & & & & & & & \\
\hline Coyote & & & & & & & & & & & & & & & & & \\
\hline$\frac{\text { Badger }}{\text { H. cat }}$ & & & & & & & & & & & & & & & & & \\
\hline illd cat & & & & & & & & & & & & & & & & & \\
\hline c1vet & & & & & & & & & & & & & & & & & \\
\hline Gr. hog & & & & & & & & & & & & & & & & & \\
\hline rotals & & & & & & & & & & & & & & & & & \\
\hline
\end{tabular}

General notes:

Fig. 13.-Field form used in the Illinois fur resource survey for recording data. 
To contact many such individuals, numerous repeat trips were necessary, and much of the interviewing was done during evening hours and over week-ends. Every furtaker, regardless of age, sex, trapping success or observance of law's, was questioned as adroitly as possible. Following each interview, all the information obtained was recorded on a form especially designed evaluation of the important fur animals, a point almost always conditioned by the monetary return; his opinion on whether these fur animals had increased or decreased in numbers since the preceding season; his estimate of trapping conditions, which, together with price, partly explain the seasonal fluctuation in catch; and the use made by the fur-taker of dog and gun

Table 2.-Chronological schedule of fur survey.

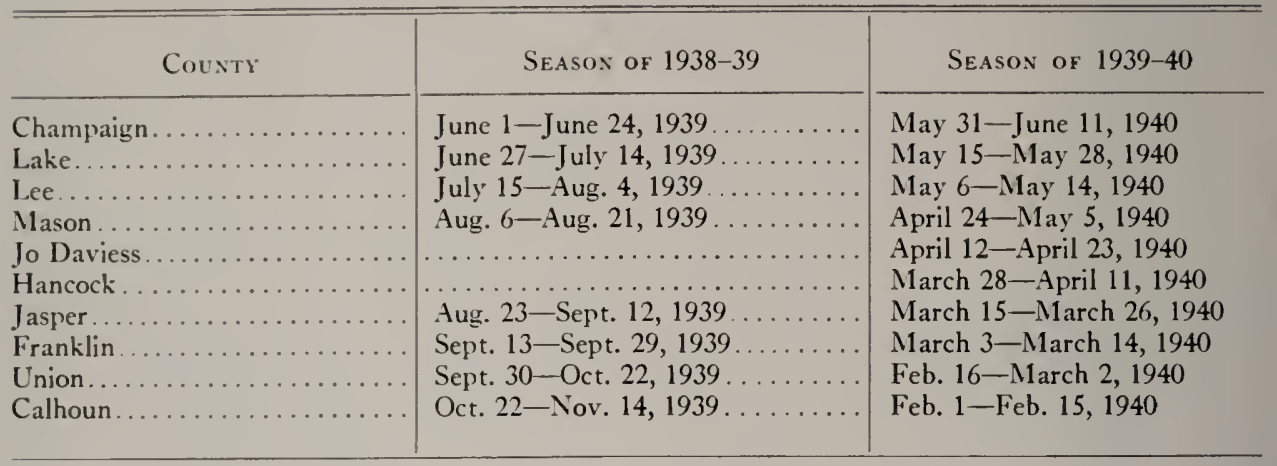

for this purpose, fig. 13. Questionable reports were corrected so far as possible by talking with neighbors, local fur dealers and state investigators (game wardens). In a very few cases, correction was accomplished by personal appraisal based on all information at hand.

Approximately 500 fur-takers, 50 dealers and several hundred other individuals were interviewed in obtaining data on the 1938-39 catch. With the exception of a few trappers or fur-hunters who moved on or off the strips between seasons, and the fur-takers in Jo Daviess and Hancock Counties, who were interviewed only once, the same individuals were contacted a second time when data on the season of 1939-40 were obtained. This duplication in sampling permitted an opportunity to evaluate the effects of price, weather and other seasonal changes on fur yield, refine sampling technique, and determine the trend in the fur catch over a 2-year period. It is probable that some individuals gave more nearly accurate answers the second year than the first.

As shown in fig. 13, the form used in recording field information included space for the fur-taker's name, address, license number, county and location of county. It included, also, space for the fur-taker's in taking furs. The catch by species, whether this was the fur-taker's estimate or actual record, was always obtained and recorded on the form; the catch by weeks was usually estimated and gives only the general trend. Under "General notes," anything considered pertinent to the study or case at hand was written in by the questioner. The relationship of sample strips to one soil type region is illustrated in fig. 12.

In the two instances in which two counties represented a region, the data for both counties were averaged and considered as representative of the region as a whole. In these two instances, Union and Calhoun counties represented the River Bluffs and Bottoms Region, and Franklin and Jasper counties represented the Gray Prairie Region. In the first case, the average fur income per square mile during the 2-year period was $\$ 20 .+3$ for Union County and $\$ 18.08$ for Calhoun County; in the second the income during the same period was $\$ 11.71$ for Jasper County and $\$ 10.48$ for Franklin County, table 18 . This close similarity of fur values for counties in the same regions indicates a relative uniformity throughout the regions, even though such similarity does not extend to each of the fur species. Since the 
River Bluffs and Bottoms and the Gray Prairie regions are among the largest and are the most diverse, it is believed that those regions represented by only one county were for most species reliably sampled.

The chronological summary of sampling, by counties, is shown in table 2 .

It is apparent from table 2 that the survey of some counties required proportionally more time than others. The investigator acquired greater proficiency with experience. To a considerable degree differences in the time required were due to differences in this proficiency, but they are also accounted for by differences in the road systems in the 10 counties, by differences in the weather and in the season. In the farm planting and harvesting seasons, it was comparatively difficult to obtain information during working hours; accordingly, many persons were interviewed at night, on Sundays or at other times that suited the convenience of the persons questioned.

The desirable and undesirable features of the sampling method used in Project $\mathrm{I}-\mathrm{R}$ are evaluated as follows:

\section{For}

1. It is rapid, as compared to a complete survey or a survey involving a larger sample.

2. It does not require intensive knowledge of the sample area on the part of the investigator.

3. It is adaptable to the convenience of residents on the sample area.

t. If planned well, it gives relatively proportional sampling of all habitats.

5. It affords opportunity for the investigator to check reports of doubtful nature by talking to a neighbor or to a local furbuyer.

6. It is more nearly representative of the total fur-taker situation, and less selective, than a survey based on catch reports of only licensed fur-takers.

\section{Against}

1. Use of roads as strip axes tends to intersect greatest human densities.

2. Sometimes it is impossible to run strips along a straight east-west or north-south course, thus interfering with the mechanical nature of the method.

3. Topography and water features of an area are not always adaptable to strip sampling. t. Percentage of area required to give a true sample is not readily determined.

5. In coverage of a large unit, as a state, time limitation may make possible only a small sample, in this case, only 1.7 per cent of the area of the state.

\section{THE FUR-TAKER}

Fur-taker is a term used in this report to indicate any individual taking furs under natural conditions by his own efforts. It includes both trappers and hunters, whether they operated day or night, with or without dogs.

In table 3, data on the number and density of Illinois fur-takers are presented by regions. The density of fur-takers in the eight regions over the 2 -year period ranges between 0.33 and 0.83 per square mile, the average for the state being 0.52 in $1938-39$ and 0.48 in $1939-40$. Furtakers numbered $29,+31$ and 27,021 , respectively, for the two seasons, as calculated from sample data. The importance of the River Bluffs and Bottoms, Black Prairie, Glacial Lakes and Gray Prairie regions are at once apparent, although for different reasons. The greatest density of fur-takers was in the Glacial Lakes Region, where numerous shallow lakes and marshes occur. 'The River Bluffs and Bottoms Region, with 0.72 fur-takers per square mile in 1938-39 and 0.63 in 193940, ranked second in density. This region, with 8,101 and 7,088 fur-takers for the two seasons, also ranked second in total number; it is third in size. The Black Prairie Region was first in total number of fur-takers, with 8,889 and 7,737 , as well as largest in size. However, this region showed only $0.5+$ and $0 .+7$ furtakers per square mile.

Fur-hunters were by far the most numerous in the River Bluffs and Bottoms and the Gray Prairie regions; both contain considerable woodland and therefore are good raccoon and opossum habitats. Regions devoid of timber, figs. 2 and 4 , ranked relatively low in the number of fur-hunters.

The above data disclose a statewide average of nearly one fur-taker for each 2 square miles.

It will be noted in table 3 that the summation of all trappers and fur-hunters exceeds the total given for fur-takers. 
This is explained by the dual activities of some fur-takers who both hunted and trapped. A reduction from the 1938-39 figure of approximately 8 per cent in the total number of trappers and hunters in 1939-40 was due probably to local scarcity of furs as a result of drought and to better employment conditions in industry. the Illinois and Mississippi rivers, the lower Kaskaskia River, the Glacial Lakes Region, and the larger streams and marshes throughout the state. 'The calculated average annual income per fur-taker over the 2 -year period was $\$+2.58$.

The number of fur-takers operating illegally in the years of the survey was

Table 3.-Number and density of Illinois fur-takers by regions, 1938-39 and 1939-40.

\begin{tabular}{|c|c|c|c|c|c|c|c|}
\hline \multirow[b]{2}{*}{$\begin{array}{l}\text { liur SURVEY } \\
\text { RegION }\end{array}$} & \multirow[b]{2}{*}{ SEASON } & \multicolumn{2}{|c|}{ Trappers } & \multicolumn{2}{|c|}{ Fur-Hunters } & \multicolumn{2}{|c|}{ FUR-TAKERS* } \\
\hline & & $\begin{array}{c}\text { Average } \\
\text { Number } \\
\text { of } \\
\text { Trappers } \\
\text { Per Square } \\
\text { Mile }\end{array}$ & $\begin{array}{c}\text { Calcu- } \\
\text { lated } \\
\text { Number } \\
\text { of } \\
\text { Trappers }\end{array}$ & $\begin{array}{c}\text { Average } \\
\text { Number } \\
\text { of Fur- } \\
\text { Hunters } \\
\text { Per Square } \\
\text { Mile }\end{array}$ & $\begin{array}{l}\text { Calcu- } \\
\text { lated } \\
\text { Number } \\
\text { of } \\
\text { Fur- } \\
\text { Hunters }\end{array}$ & $\begin{array}{c}\text { Average } \\
\text { Number } \\
\text { of Fur- } \\
\text { Takers } \\
\text { Per Square } \\
\text { Mile }\end{array}$ & $\begin{array}{l}\text { Calcu- } \\
\text { lated } \\
\text { Number } \\
\text { of } \\
\text { Fur- } \\
\text { Takers }\end{array}$ \\
\hline \multirow{3}{*}{ Northwest Hills... } & $1938-39$ & 0.40 & 328 & 0.15 & 123 & 0.50 & 410 \\
\hline & $1939-40$ & 0.41 & 337 & 0.12 & 98 & 0.49 & 402 \\
\hline & 1938-39 & 0.29 & 941 & 0.20 & 649 & 0.41 & 1,330 \\
\hline Western Prairie. & $1939-40$ & 0.36 & 1,168 & 0.26 & 843 & 0.47 & 1,525 \\
\hline River Bluffs and & $1938-39$ & 0.40 & 4.500 & 0.42 & 4,725 & 0.72 & 8,101 \\
\hline Bottoms...... & $1939-40$ & 0.33 & 3,713 & 0.40 & 4,500 & 0.63 & 7,088 \\
\hline Northwestern & $1938-39$ & 0.49 & 2,218 & 0.11 & 498 & 0.56 & 2,535 \\
\hline \multirow[t]{2}{*}{ Sand Prairie. } & $1939-40$ & 0.46 & 2,082 & 0.10 & 453 & 0.51 & 2,308 \\
\hline & $1938-39$ & 0.82 & 1,343 & 0.02 & 33 & 0.83 & 1,360 \\
\hline \multirow[t]{2}{*}{ Glacial Lakes.... } & $1939-40$ & 0.71 & 1,163 & 0.03 & 49 & 0.73 & 1,196 \\
\hline & $1938-39$ & 0.52 & 8,560 & 0.05 & 823 & 0.54 & 8,889 \\
\hline Black Prairie. & $1939-40$ & 0.46 & 7,573 & 0.02 & 329 & 0.47 & 7,737 \\
\hline Central & $1938-39$ & 0.39 & 2,222 & 0.12 & 684 & 0.44 & 2,507 \\
\hline \multirow[t]{2}{*}{ Sand Prairie.... } & $1939-40$ & 0.39 & 2,222 & 0.11 & 627 & 0.41 & 2,336 \\
\hline & $1938-39$ & 0.23 & 2,996 & 0.17 & 2,214 & 0.33 & 4,299 \\
\hline Gray Prairie..... & $1939-40$ & 0.22 & 2,866 & 0.19 & 2,475 & 0.34 & 4,429 \\
\hline & $1938-39$ & 0.408 & 23,108 & 0.172 & 9,749 & 0.52 & 29,431 \\
\hline Illinois. & $1939-40$ & 0.373 & 21,124 & 0.165 & 9,374 & 0.48 & 27,021 \\
\hline
\end{tabular}

*The total number of fur-takers is lower than the sum of trappers and fur-hunters because some individuals were listed as both trappers and fur-hunters.

The survey brought out the surprising fact that most of the fur-takers in Illinois are men, who trap a very large proportion of the annual fur crop; schoolboy trappers are distinctly in the minority. The average age of fur-takers contacted was 33 years; the oldest was 74 and the youngest 11 . The main reason for the relatively small number of boy trappers is the highly developed Illinois school system, which has enrolled almost all rural youths. Hours which schoolboys formerly spent on traplines are now spent in riding to and from town or in participating in high school activities. Professional trappers, averaging at least middle age, dominate all of the best trapping grounds, such as those along difficult to determine. In some localities probably as high as 10 per cent of them were serious violators of the game code, while in other places practically all operated within the law.

Pertinent data on the calculated number of trappers and the number of trappers' licenses sold in Illinois are summarized for the period covered by the survey in table 4.

Study of table 4 discloses for 1938-39 an obvious discrepancy between the number of licenses sold by the State Department of Conservation and the number of licensed fur-takers, as calculated from figures derived from the survey. Since the Illinois law in both seasons covered by this 
report required each fur-taker not residing on the land on which he operated to purchase a license for each unit of 25 traps, obviously the calculated number of licensed fur-takers should have been smaller than the number of licenses sold. Such was the case in 1939-40. But in 1938-39 the number of fur-takers, as calculated from interviews, was greater than the number of licenses sold.

This discrepancy may be due to (1) inadequate sampling in the state, wherein t. Data contained in table 1 of the Mohr report indicate that ++ per cent of the furtakers were licensed in 1938-39 and 61 per cent in 1939-40.

The percentages for 1939-40 from the present and the Mohr reports must be considered surprisingly close in view of differences in methods of investigation. Despite wide differences in the figures from the two reports for 1938-39, the percentages for the two seasons derived from these reports reinforce each other

Table 4.-Fur-takers' licenses sold by the State Department of Conservation, the total number of fur-takers (calculated from data gathered from interviews with fur-takers) and the number of licensed fur-takers (calculated from interviews and from monthly reports to the Department of Conservation), 1938-39 and 1939-40, in Illinois.

\begin{tabular}{|c|c|c|c|c|c|c|c|}
\hline \multirow{2}{*}{ SEASON } & \multirow{2}{*}{$\begin{array}{l}\text { Number } \\
\text { of } \\
\text { Licenses } \\
\text { Sold }\end{array}$} & \multirow{2}{*}{$\begin{array}{c}\text { Total } \\
\text { Number of } \\
\text { Fur-TaKers, } \\
\text { Calculated } \\
\text { From } \\
\text { INTERVIEWS } \\
\text { With } \\
\text { Fur-TaKers }\end{array}$} & \multicolumn{2}{|c|}{$\begin{array}{c}\text { Licensed Fur- } \\
\text { TaKers, Calculated } \\
\text { From INTERVIEWs } \\
\text { WrTh } \\
\text { Fur-TaKers }\end{array}$} & \multicolumn{2}{|c|}{$\begin{array}{c}\text { Licensed Fur- } \\
\text { Takers, Calculated } \\
\text { From Fur-Takers' } \\
\text { Monthly Reports } \\
\end{array}$} & \multirow{2}{*}{$\begin{array}{c}\text { Calcu- } \\
\text { lated } \\
\text { Number } \\
\text { of } \\
\text { Licenses } \\
\text { Per } \\
\text { Fur- } \\
\text { Taker } \dagger\end{array}$} \\
\hline & & & Number & $\begin{array}{c}\text { Per Cent } \\
\text { of Total } \\
\text { Number of } \\
\text { Fur- } \\
\text { Takers }\end{array}$ & Number* & $\begin{array}{c}\text { Per Cent } \\
\text { of Total } \\
\text { Number of } \\
\text { Fur- } \\
\text { Takers }\end{array}$ & \\
\hline $\begin{array}{l}1938-39 \\
1939-40\end{array}$ & $\begin{array}{l}15,472 \\
18,277\end{array}$ & $\begin{array}{l}29,431 \\
27,021\end{array}$ & $\begin{array}{l}15,820 \\
15,982\end{array}$ & $\begin{array}{l}54 \\
59\end{array}$ & $\begin{array}{l}12,810 \\
16,615\end{array}$ & $\begin{array}{l}44 \\
61\end{array}$ & $\begin{array}{l}1.2 \\
1.1\end{array}$ \\
\hline
\end{tabular}

* Derived by Molir and contaired in table 1 of the Molir report, published herewith as Article 6.

tCalculated by Mohr by determining the number of reporting licensees and dividing the number of licenses sold thereto by the number of licensees.

only 1.7 per cent of the total area was actually covered, (2) disproportionate sampling as between rural and urban communities (the percentage of trappers required to purchase licenses is relatively low in rural communities and high in urban communities) and (3) inaccurate statements by the fur-takers interviewed.

Figures calculated from interviews with fur-takers, if accepted at their face value, would indicate that license holders constituted $5+$ per cent of the total number of fur-takers for 1938-39 and 59 per cent for 1939-40. But, as the figure 15,820 for the calculated number of licensed furtakers for 1938-39 is obviously inaccurate, the percentage derived for this season cannot be considered valid.

Using the data contained in fur-takers' monthly reports, Mohr calculated that the number of licensed fur-takers was 12,810 in 1938-39 and 16,615 in 1939-40, table in indicating a greater percentage of licensed fur-takers for the second season than the first.

\section{ILLINOIS FUR LAWS}

During the period covered by this survey, 1938-39 and 1939-40, Illinois statutes did not require the purchase of a trapping license by the fur-taker operating on the land on which he resided if he used 25 or fewer traps; however, if the fur-taker used more than 25 traps he was required to purchase a trapping license for each unit of 25 traps or fraction thereof in excess of the 25 to which residence on the land entitled him. For all other furtakers, both hunters and trappers, the law required the purchase of one license for each 25 or fewer traps at a cost of $\$ 2$ for a resident and $\$ 10$ for a non-resident of Illinois. These fees included the cost of 
tags, which were supplied by the State Department of Conservation, and one of which was required to be attached to each trap. In the season of 1939-40, even the trapper exempt from the license regulation was required to tag his traps as specified above, tags being supplied by the Department at cost of production.

The trapping season of 1938-39 was staggered both by zones and by species. In all zones, and for all protected furbearing species on which an open season wils provided except muskrats and foxes, it opened Nov. 15, but closed Jan. 15 in the southern and central zones and Jan. 31 in the northern zone. The muskrat season opened Nov, 15 in the northern zone, but not until Dec. 1 in the central and southern zones. It closed Jan. 31 in all zones, 16 days later than the season on most other species in the two more southern zones. Only in the northern zone did the muskrat season coincide with open dates for other protected fur animals. Foxes, in the northern and central zones, were unprotected by a closed season; in the southern zone they were included in the open season with most other fur species. Certain northern counties paid a bounty on foxes. No distinction was made between red and gray foxes. No limits were placed on the take of any furbearer on which an open season was declared. Muskrats could be taken only with traps, and no trap could be set within 10 feet of a muskrat house or den. Dog training was permitted during the period of Aug. 15 to March 31.

In 1939-40, there was no staggering of seasons by species. The trapping season began Nov. 15 in the northern and central zones and closed Jan. 31 in the former and Jan. 15 in the latter. In the southern and central zones, the fox season coincided with that of other fur-bearing animals. In the northern zone, there was no closed season on foxes.

The codes applicable to the two seasons covered by the survey provided for monthly catch reports from all persons, licensed and unlicensed, taking fur animals, but survey calculations indicated that only 4,105 fur-takers, or 26 per cent of the calculated 15,820 licensed, made these reports in 1938-39, and only $2,1+4$, or 13 per cent of the calculated 15,982 licensed, made these reports in 1939-40. In 1939-
40 a difficulty arose in the distribution of the blank forms, which is believed to explain the difference for the 2 years.

\section{ILLINOIS FUR ANIMALS}

The income from the sale of Illinois raw furs, estimated to vary between 1 and 2 million dollars annually, is derived with little direct investment and in the almost complete absence of management. This income is distinctive in that it is distributed to every county in the state, chiefly among people most in need of additional funds. The main cost is the time required to harvest the crop, which is limited chiefly to the rural and small town populations. The trapping season fits into the slack part of the year and provides a timely source of cash during the winter months, especially the holiday period.

The following discussions of the yield and value of Illinois furs are presented by species, and constitute the bulk of this report. No attempt to include habits or life histories has been made. With each specific discussion is included a tabulated summary of field data, which supplies the basis for the discussion.

The average fur prices received by furtakers were found by averaging a large series of pelts for each species from each region. The average prices thus determined are given in table 5 .

At the time of the survey, a number of Illinois furbearers occurred in such thin populations or were restricted to so small a part of the state that the sampling methods used were inadequate in evaluat-

Table 5.-Average prices received by furtakers for Illinois raw furs, 1938-39 and 1939 . 40 (to nearest $\$ 0.05$ ).

\begin{tabular}{|c|c|c|}
\hline \multirow{2}{*}{ SPEcies } & \multicolumn{2}{|c|}{ Average Price for Season } \\
\hline & $1938-39$ & $1939-40$ \\
\hline Muskrat...... & $\$ 0.80$ & $\$ 1.00$ \\
\hline Opossum ....... & 0.20 & 0.20 \\
\hline Raccoon....... & 2.00 & 2.00 \\
\hline Skunk......... & 0.75 & 1.00 \\
\hline Mink......... & 7.00 & 6.00 \\
\hline Red fox........ & 3.00 & 2.75 \\
\hline Gray fox...... & 1.75 & 1.75 \\
\hline Weasel......... & 0.35 & 0.35 \\
\hline Coyote..... & 2.00 & 2.00 \\
\hline
\end{tabular}


ing their status. These species are the badger, coyote, otter, beaver and bobcat. The house cat, abundant in every community, is of little importance in the fur trade. In several instances, especially for the otter, beaver and bobcat, the survey was supplemented by special investigation by the senior author and others.

\section{Muskrat*}

'The muskrat, taken in all Illinois counties and common to practically all northern and many southern aquatic habitats in the state, represented over 68 per cent of the calculated total fur catch for the two seasons of the survey, table 20. For the season of 1938-39, the calculated catch was $88+, 395$ muskrats, worth $\$ 707,456$; and for $1939-40$, it was $66+, 831$ muskrats, worth $\$ 66+, 831$, table 6 . Muskrat furs, therefore, represented a sizable business, centered mainly in the northern half of Illinois and operated for the most part by older, experienced trappers. Income is practically the sole incentive for taking muskrats, whereas with several other Illinois furbearers sport is partly responsible for the take. The state's muskrat crop, although largely unmanaged and indiscriminately harvested, continues to provide all or part of the winter livelihood of 20,000 or more persons, many of whom are heads of families.

In Illinois, the muskrat has demonstrated marked ability to withstand trapping and environmental losses, probably because of its high reproductive potential. Simple management practices would undoubtedly result in a greater return from muskrats.

Popularity.-Among Illinois fur-takers the muskrat was the third most popular and sought-for species. In 1938-39. 312 of the trappers questioned desired more and 7 fewer; in 1939-40, 326 wanted more and 2 wanted fewer. Only the raccoon and mink were more highly regarded. A number of reasons account for the muskrat's popularity, chief of which are relative abundance, ease of trapping and handling, and the comparative value of the fur.

Damage and Control.- The total of 9 fur-takers who opposed an increase in the muskrat population were motivated by

*The scientific names of fur animals mentioned in this paper are listed facing the contents page. damage done in some instances to cornfields, ditches and tiles. Loss from such damage may be appreciable, especially where the destruction of dams and plugging of ditches is involved. Errington (1938) has shown that income from muskrat pelts outweighs the damage done by the animals to crops, including value of labor and equipment. An annual fur income of approximately $\$ 30$ per mile of ditch was reported (Yeager 1943b) in Champaign County; more than 90 per cent of this was derived from muskrats. Four farmer-trappers in Champaign County in 1938-39 took $63+$ muskrats from 8 miles of drainage ditches. The pelts were worth $\$ 507.20$, or $\$ 63.40$ per linear mile. This income is in excess of the value of any damage incurred. The ditches involved were better than average as muskrat habitat, but crop damage is generally proportional to muskrat density, and other ditches would show both a lower degree of damage and a lower fur income. In any case, the fur income could be expected to exceed the value of crop losses.

In the Black Prairie and to a lesser degree in the Northwestern Sand Prairie, farmers who trap or lease trapping rights consider the loss of corn due to muskrat damage a part of the cost in producing the fur crop. Farmers who see the loss in the light of a needless waste make more or less effective efforts to keep their ditches free of muskrats.

The control of muskrats under conditions where their presence is definitely destructive is not well discussed by any one writer. Dams can be protected by covering them with galvanized poultry wire of 1 -inch mesh, or, in some cases, damage can be prevented by building the dams with slopes so slight that burrowing is discouraged. A slope of at least 7 or 8 to 1 is necessary to discourage burrowing, and is, of course, impractical in most instances. Ditches can be protected by leaving an uncultivated strip 8 or 10 feet wide along each side. Planted to shrubs and unpastured, such strips make excellent game coverts in addition to being resistant to caving such as is sometimes caused by muskrat burrows. Ditches with sides sloped at the time of construction are resistant to caving. The writers believe that the most practical control is trapping during the open season, the amount of 


\begin{tabular}{|c|c|c|c|c|c|c|c|c|c|c|}
\hline \multirow{2}{*}{ 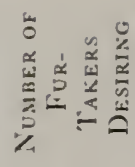 } & 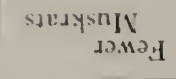 & 00 & -- & -0 & -0 & 00 & $n-$ & -0 & 00 & $n a$ \\
\hline & 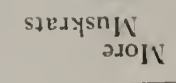 & సి & व્స ले & $\stackrel{m}{=}=$ & $\infty$ & 유 & 尔 & లిల్ల & 우요 & ल సี \\
\hline \multirow{3}{*}{ 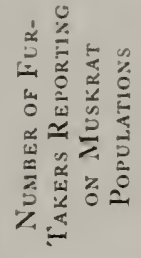 } & วระวגวð & $\because 0$ & $\stackrel{\infty}{ }$ & $2 n$ & $2 a$ & हె & हृते & $\vec{\lambda}=$ & 足孚 & શิ) \\
\hline & วйчечว о & $\varrho+$ & $n$ & $\approx N$ & in in & $a \simeq$ & 09 & $q^{\text {in }}$ & $n N$ & 39 \\
\hline & วระวدગ & $m=$ & -6 & $N-$ & กี่ & $\stackrel{\infty}{=}$ & 워 & Nin & $\operatorname{ta}$ & $\Re \stackrel{\Upsilon}{\Re}$ \\
\hline \multirow{2}{*}{ 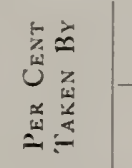 } & sıวun $_{H}$ & 00 & 00 & 00 & 00 & 00 & 00 & 00 & 00 & 00 \\
\hline & s.added. & $8 \S$ & 88 & $8 \cong$ & $\S \S$ & 88 & $8 \cong$ & $8 \&$ & $8 \cong$ & 88 \\
\hline \multicolumn{2}{|c|}{ 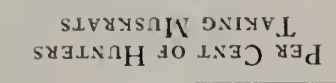 } & 00 & 00 & 00 & 00 & 00 & 00 & 00 & 00 & 00 \\
\hline \multicolumn{2}{|c|}{ 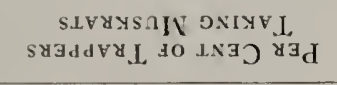 } & $\infty \infty$ & $n \mathbb{R}$ & $\stackrel{\infty}{\longrightarrow} \stackrel{\circ}{n}$ & $\infty 8$ & ถ้ ฉ & 요 & $\hat{\alpha} \alpha$ & $\infty \infty$ & ప \\
\hline \multicolumn{2}{|c|}{ 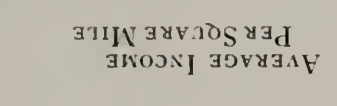 } & $\begin{array}{l}3= \\
\infty=1 \\
\infty \\
\infty\end{array}$ & $\begin{array}{l}\tilde{m} \cong \\
\dot{m} \text { in }\end{array}$ & $\stackrel{\infty}{\infty} \underset{-\infty}{\infty}$ & 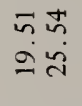 & 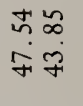 & $\begin{array}{l}\infty \stackrel{\infty}{\sim} \bar{n} \\
\tilde{N} \infty\end{array}$ & $\begin{array}{l}\text { ț } \\
\therefore \text { in }\end{array}$ & $\begin{array}{l}\text { nू } \\
\text { ì } \\
i\end{array}$ & 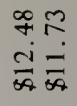 \\
\hline \multicolumn{2}{|c|}{ 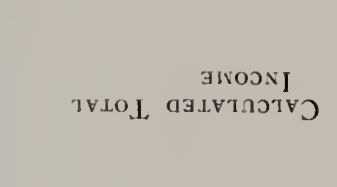 } & 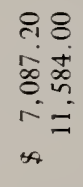 & 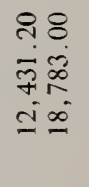 & 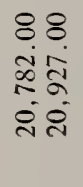 & 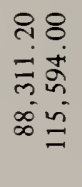 & 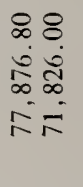 & 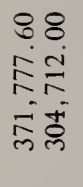 & 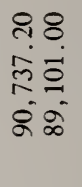 & 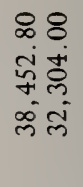 & 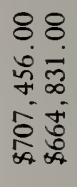 \\
\hline \multicolumn{2}{|c|}{ 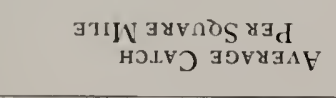 } & $\begin{array}{l}\Omega= \\
0 \pm \\
0 \pm\end{array}$ & $\begin{array}{l}92 \\
\text { gin } \\
\text { in }\end{array}$ & $\vec{j} \infty$ & $\begin{array}{l}\text { ले से } \\
\text { ते ते }\end{array}$ & 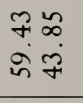 & 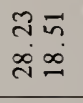 & 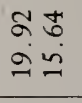 & 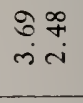 & 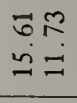 \\
\hline \multicolumn{2}{|c|}{$\begin{array}{c}\text { HOLVว } \\
\text { TVLO.L बЗLVTกJTY }\end{array}$} & 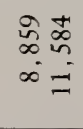 & $\begin{array}{l}\hat{\approx} \cong \\
\tilde{n} \\
\sim \infty\end{array}$ & $\begin{array}{l}\text { \&ू̃ } \\
\text { ๙ूं }\end{array}$ & 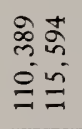 & 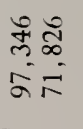 & 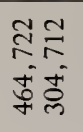 & $\begin{array}{l}+50 \\
+50 \\
=0 \\
=\infty\end{array}$ & 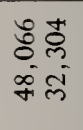 & 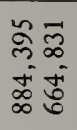 \\
\hline \multirow{2}{*}{\multicolumn{2}{|c|}{ 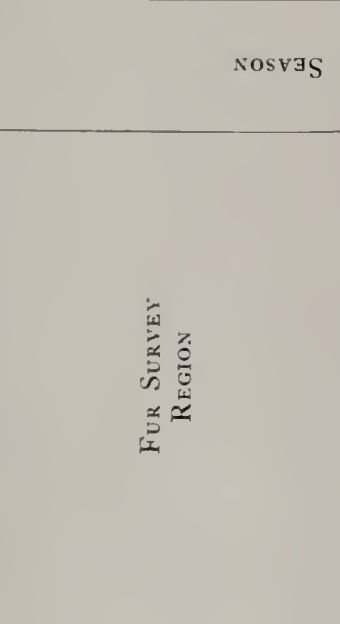 }} & 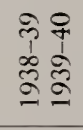 & 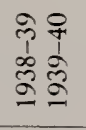 & $\begin{array}{l}\text { के } \\
0 \\
0 \\
\approx \sigma \\
\sigma\end{array}$ & 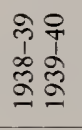 & 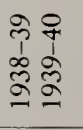 & 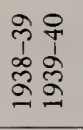 & 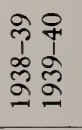 & 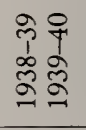 & 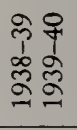 \\
\hline & & 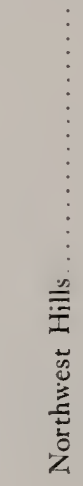 & 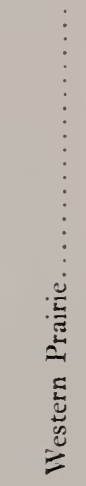 & 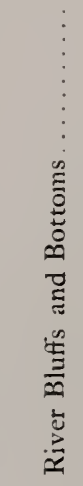 & 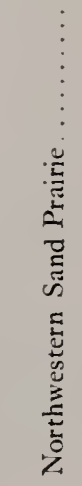 & 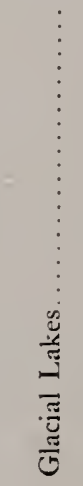 & 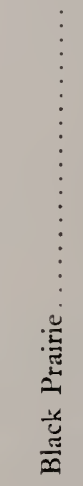 & 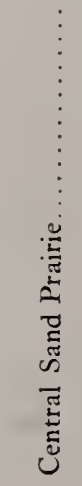 & 菢 & $\begin{array}{c}\vdots \\
\vdots \\
\stackrel{n}{\Xi} \\
\vdots\end{array}$ \\
\hline
\end{tabular}


trapping being regulated according to the degree of control needed. Usually, the services of skillful trappers can be enlisted.

Populations.-Of $6+3$ trappers expressing an opinion relative to changes in muskrat population, for the season of bearing on muskrat catches, reproduction and dispersal (Errington 1937b, 1939, 1940). For example, the 1938-39 muskrat catch in Illinois was, according to numerous experienced trappers, lower than that of the preceding year, a drop believed

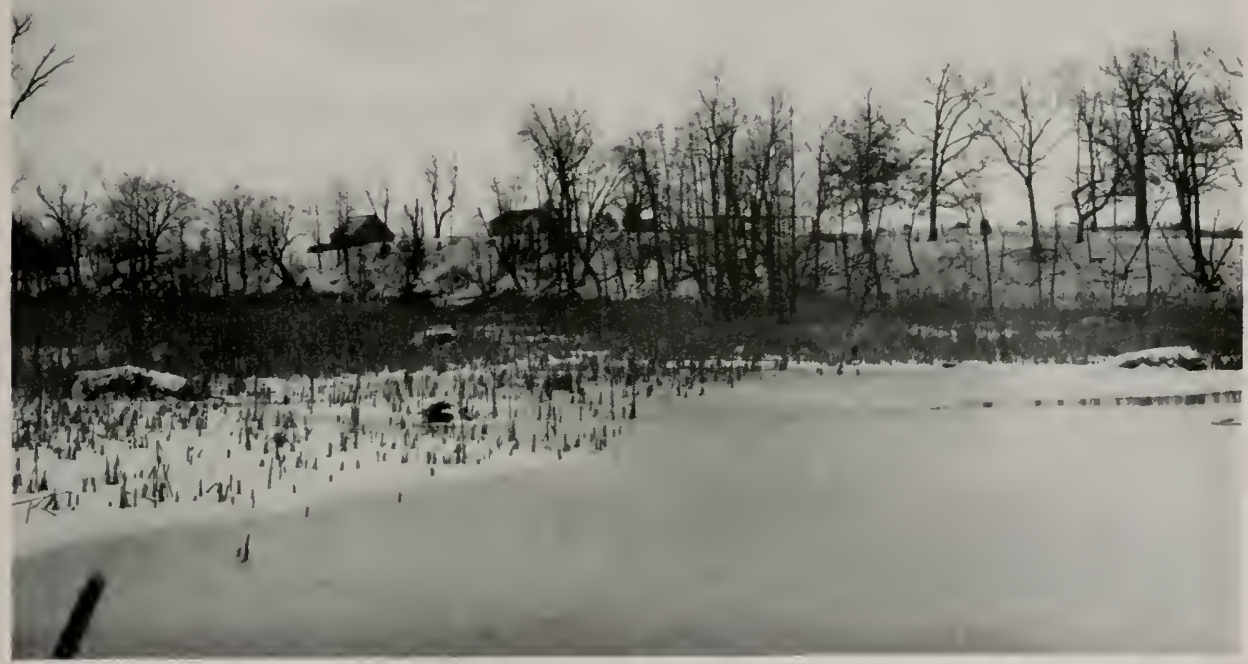

Fig. 14.-A spring-run type of marsh, highly productive of muskrats, Vermilion County. This marsh, less than 2 acres, annually produces 20 to to muskrats.

1938-39, 173 indicated a decrease, 63 no change and 73 an increase as compared with the preceding season; for the season of 1939-40, 207 trappers reported a decrease, 49 no change and 78 an increase as compared with the preceding season. Many of the older, experienced trappers were able to recall fluctuations for the 5 -year period preceding this study. Near$\mathrm{ly}$ all of these individuals agreed that a general population decline had occurred; this decline appeared to be less rapid in the northern third than in other parts of the state.

Local muskrat populations were found to vary widely in density, a condition making unreliable the use of restricted observations as criteria for statewide trends. Weather has a highly important to have been due in part to heavy floods at a time destructive to new-born litters. The decrease in the 1939-+0 catch, which was not experienced in 17 northwestern counties, is believed to have been due mainly to drought over most of the state during the late summer and fall of 1939. Lack of water forced many animals to migrate, and consequently exposed them more than usual to predation. 'The northwestern corner of the state, in contrast, experienced normal weather during the spring, summer and fall, and a moist open season, conducive to effective trapping. Because of normal young-rearing and harvesting, a normal crop was taken there.

The writers believe that, except for the possible but unknown effect of cycles, the following factors are chiefly responsible 
for the recent decline in muskrat numbers, which is associated with reduced range.

1. Overtrapping, arising from demand for muskrat furs and resulting in insufficient breeding stock.

2. Drainage of potential agricultural land, greatly reducing the aquatic habitat.

3. Shortage of food, due to grazing, burning and clearing land.

4. Predation, resulting largely from exposure of the animals during enforced mi-

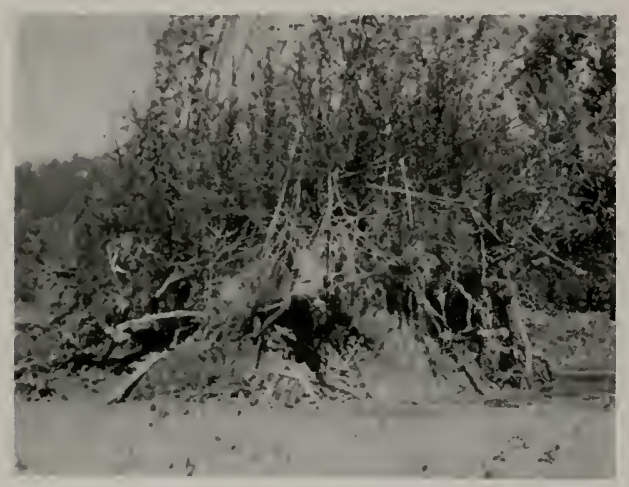

Fig. 15.-Three entrances to muskrat den in Hooded stump, exposed by sudden drop in water level, Illinois River, Calhoun County. Muskrats may dig new tunnels to correspond with changes in water level.

gration in search of water, and from a shortage of food and cover along streams and ditches.

Habitats.-In Illinois, as elsewhere, trappers make a distinction between marsh and bank muskrats. Marsh muskrats, except along levees and banks, build houses of cattails, bulrushes, water smartweed and similar materials; bank muskrats simply tunnel runways, beginning under water and ending above water. 'The marsh animals are found principally in the northern half of the state, and along the Mississippi and Illinois rivers, fig. 7 and frontispiece. Bank muskrats inhabit drainage ditches, ponds and streams throughout lllinois, fig. 8. In general, it appears that muskrats build houses if possible. Even in stripmine areas, where conditions favor bank dens, muskrats build an occasional house of cattail or other vegetation where its occurrence is abundant enough and the area of shallow water large enough for the purpose (Yeager 19+2).
In the two seasons covered by this study, the greatest production of marsh muskrats came from the Glacial Lakes Region; the yield in this area averaged about 50 per square mile. The Northwestern Sand Prairie produced about 25 per square mile, the Central Sand Prairic about 18 per square mile, table 6 .

Marsh muskrats occupy an environment which, under ideal conditions, is favored by relatively stable water levels and an abundance of vegetation (Typhia, Scirpus, Polygonum and Potamogeton), fig. 14. Although the bank habitat is generally less favorable than the marsh habitat, the total catch of bank muskrats in Illinois exceeds that of the marsh animals. This is due to the much larger range inhabited by bank-dwelling animals, centering in the Black Prairie where streams and drainage ditches afford extensive bank habitations.

Muskrats show excellent adaptability to the changes and perversities of environment, fig. 15. Food shortage, drought and flood occasionally decimate their numbers or force migration, but seldom extirpate them from a given stream or pond. Throughout the Black Prairie, thousands of shallow-water ditches offer, in normal seasons, habitats with sufficient food, water and cover, fig. 8. During wet years these ditches provide excellent range. The catch varies by years, apparently according to weather conditions. In 1938-39 the total muskrat catch in the Black Prairie $\mathrm{Re}$ gion averaged 28.23 per square mile; in 1939-40, which was very dry over most of the region, the catch was only 18.51 per square mile.

Muskrat habitats in the Gray Prairie, the River Bluffs and Bottoms and the Western Prairie regions have low carrying capacities. The intermittent character of the streams and general deficiency of aquatic vegetation, as well as heavy trapping, explain the comparatively low catch of about two to five animals per square mile, table 6.

The quality or type of the habitat has considerable effect on the more obvious food habits of muskrats. The utilization of such items as willow, cottonwood, fish, mollusks and crustaceans seems to be more common among stream than among marsh muskrats, perhaps because of a shortage of cattails, bulrushes and similar vegeta- 
tion in the streams. During the survey, this difference in food habits was frequently commented upon by veteran trappers.

Food, in turn, apparently has a considerable effect on fur quality. Stream muskrats, probably because of a deficiency of quality foods, and possibly because of food shortage, yield pelts known to trappers and to the fur trade as "papery."
1939, limited the taking of muskrats to spring traps having a jaw spread of not over 6 inches. The 1937 code did not limit the size of jaw. The codes put into effect in both these years specified that a trap might not be set or placed within 10 feet of any muskrat house or den, but trapping nearer than this distance was found to be a common practice. There

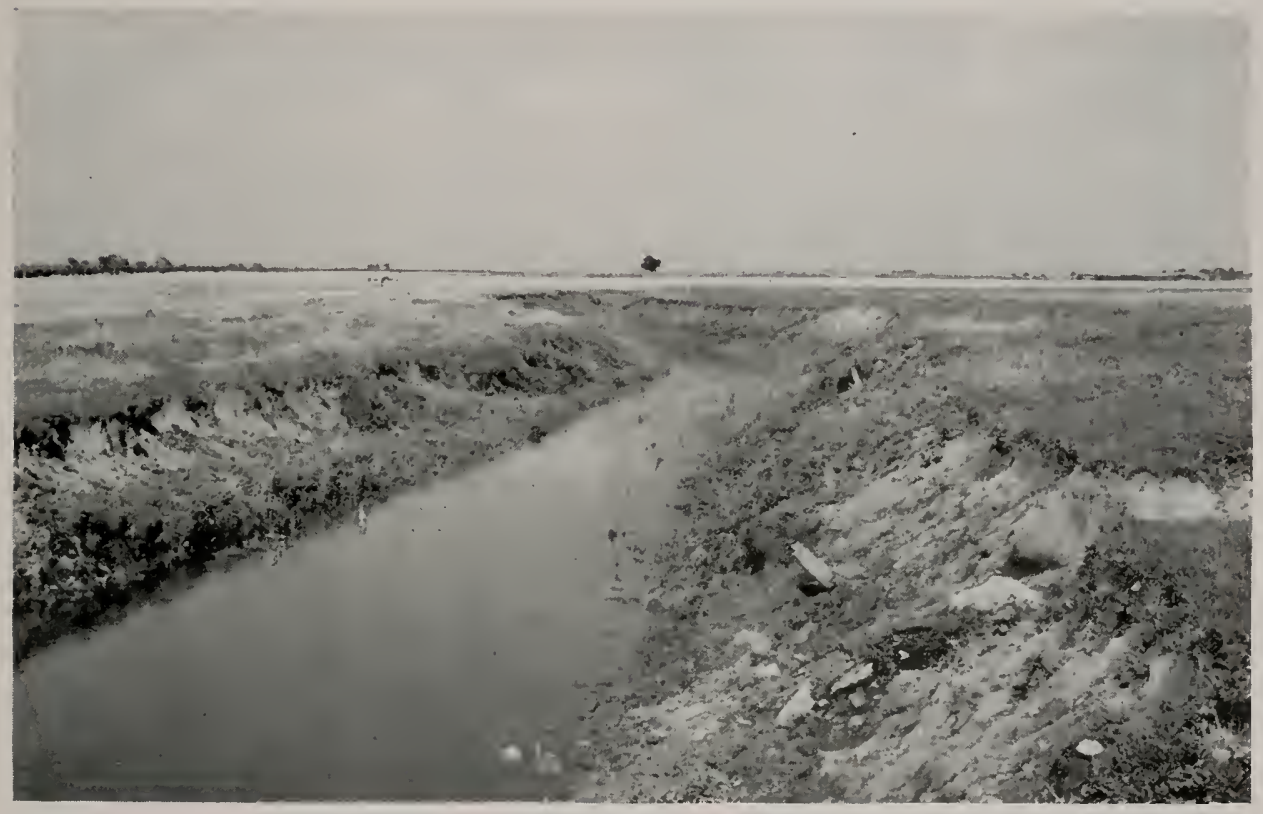

Fig. 16.-Grazed ditch with eroding banks, Champaign County. Such waterways produce little muskrat food; burrows are often destroyed by stock.

The leather of these pelts is thin, the hair color is a lighter brown and the fur is neither so long nor so thick as that of marsh muskrats. Fur buyers commonly pay 10 to 20 per cent more for marsh or ditch-grown pelts than for "papery" skins.

Water contaminated with oil sludge or residues from coal mines destroys plant life, thus reducing habitat quality. Also, it is frequently noticed that muskrats may be scarce along, or absent from, streams contaminated by mine wastes, and from both streams and ditches subject to heavy grazing, fig. 16. Pollution has damaged to varying degrees the muskrat habitat along the Rock, Galena and upper Illinois rivers and around the centers of oil activity throughout the Gray Prairie Region.

Trapping.-The Illinois Game Code in effect for the 2 years beginning July 1, was no limitation of take in any of the three zones in either year of the survey. Spearing and shooting of muskrats were properly illegal, but, as the regulation respecting these methods of kill is difficult to enforce, some muskrats were so taken in both 1938-39 and 1939-40. Because their numbers could not be ascertained, thes were not considered in the data.

Water sets, unbaited or "blind," are the standard with Illinois muskrat trappers. Traps are placed in runs at the entrance of holes, dens or houses, on logs, stumps or floating chunks, and at feed beds. Usually some provision is made for drowning the animals, in order to reduce the percentage of escapes effected by wringing off a foot. The staking of traps in or toward deep water and the use of large, heavy traps are the most common 
methods of assuring drowning. Killer type traps are seldom used in Illinois, even on open marshes. Under-ice trapping is common in the Glacial Lakes Region and in the Illiniois River marshes. Many trappers favor ice trapping, since it enables them to define used runs more easily, and "wring-offs" are practically eliminated. In under-ice operation, traps are simply set in muskrat runs through holes chopped in the ice and staked by driving a willow or buttonwood branch through the ring at the end of the trap chain. The traps are seldom weighted or covered. Similar sets are used in trapping bank muskrats, except for the "run" method employed in the marshes, which is impossible under bank conditions.

Fluctuating water levels are the bane of both marsh and stream trappers. A change of only a few inches in the level, either up or down, may throw an entire trapline out of order. The increased diversion of water, December, 1940, from Lake Michigan into the Illinois River was followed by numerous complaints by trappers whose traps in some instances were so deeply covered that catches were impossible. Traps replaced were later left on dry ground. In meeting the problem of fluctuating water in streams, some trappers anchor logs, boards or other floating debris with wire in such manner that these rise and fall with the water. Traps set thereon, unless rendered inoperative by freezing, are always in working order and are in excellent locations.

A very large percentage of the annual muskrat catch is taken during the first few weeks of the season. As much as 50 to 85 per cent may be caught during the first 15 nights. It is well known that muskrat furs are not prime until December 1 or after, and that the best skins are taken in January and February. The facts that the muskrat is by far the most important species and that a large portion of the catch is made during the first part of the season furnish good arguments in favor of a trapping season opening on Dec. 1.

The value of the muskrat resource is such that the annual harvest of furs is taking on an organized form, wherein the leasing of grounds or trapping rights has become common. During the years of the survey, this leasing system prevailed along the large river marshes, the glacial lakes marshes and the hundreds of drainage ditches throughout the Black Prairie Region. Some of the best ditches in this region were leased at $\$ 20$ per linear mile. In some cases, the rental was 50 per cent of the catch, the trapper furnishing all necessary supplies and labor. In the southern half of the state leasing of grounds was found to be less common.

A point of interest noted during the survey was the abundance of Norway or barn rats, Rattus norvegicus (Erxleben), reported taken in muskrat sets. In 193839, a Lee County trapper, using 30 traps, claimed to have taken 100 muskrats and 53 barn rats; another trapper in Lee County, using 25 traps, claimed to have caught 50 muskrats and 20 barn rats. Water sets were used exclusively in these instances, indicating that, if these claims are valid, barn rats are not reluctant to swim or wade in water up to depths of several inches. General complaints of barn rat abundance were received from trappers in Lee, Jasper and Champaign counties. In 1939-40 the same trappers reported fewer barn rat catches. Experienced trappers are of the opinion that these rats compete keenly with muskrats for food and territory, and that they are potential if not actual predators on muskrat young. It may be that some of the animals reported by trappers as barn rats were actually kit muskrats.

Management.-On the basis of the information at hand, the writers believe that the following steps would be effective in checking further depletion in muskrat range and numbers, thereby placing the species in a more secure position in Illinois.

1. Enact and enforce more effective laws against oil and mine pollution of water habitats.

2. Enact seasons opening Dec. 1 and closing Jan. 31 in all zones. This step would insure a higher average quality in muskrat fur and aid in preventing overtrapping during mild November weather. If prices are high, trappers will operate during the adverse weather of December and January.

3. Allow traps to be placed 3 feet instead of 10 feet from houses and dens. Trapping closer than 10 feet is a statewide practice; enforcement of the 10 -foot regu- 
lation provided under the law in force at the time of the survey is practically impossible.

t. Enforce more effectively regulations against spearing and shooting of muskrats.

\section{Opossum}

The opossum, fig. 17 , is taken in every Illinois county, but occurs in comparatively small numbers in the northern part of the state. For the season of 1938-39 the calculated catch was $2+t, 2+2$ pelts, worth $\$+8,8+8.40$; and in $1939-40$ the catch was 171,590 pelts, worth $\$ 3 t$,318.00 , table 7 . The catch figures do not represent the total numbers of opossums taken because very low prices for opossum furs in both seasons caused an unknown percentage to be thrown away by furtakers. Another, and perhaps appreciable, part of the total take was used for food, especially by people of foreign extraction in the southern Illinois coal region, and undoubtedly pelts of many of the animals so used were not sold. The actual take may easily have been 50 per cent greater than the figures given.

Popularity.-Fur-takers showed comparatively little enthusiasm concerning the opossum. Of the fur-takers questioned in 1938-39, 23t desired more and tt fewer opossums; of those questioned in 1939-40, 316 wanted more and +3 wanted fewer, table 7 . Coming directly from trappers and hunters, these figures reflect distinct lack of appreciation. Not even the skunk ranked so low in popularity among furtakers. Only gray fox, red fox and weasel showed lower popularity percentages, but none of these ranked among the most important Illinois fur animals. Some furtakers objecting to a further increase of opossums were motivated by the nuisance caused by this species, as when getting into traps set for more raluable animals. Others resented opossum depredation on poultry. A few night hunters were interested in coon hunting only, and thus found the abundance of opossums objectionable. The principal reason for the opossum's position in public esteem is the low value of its fur; a higher value would register an immediate and positive change in attitude. Among non-fur-takers orer the state, this species probably ranks next to foxes and weasels in unpopularity, a posi-

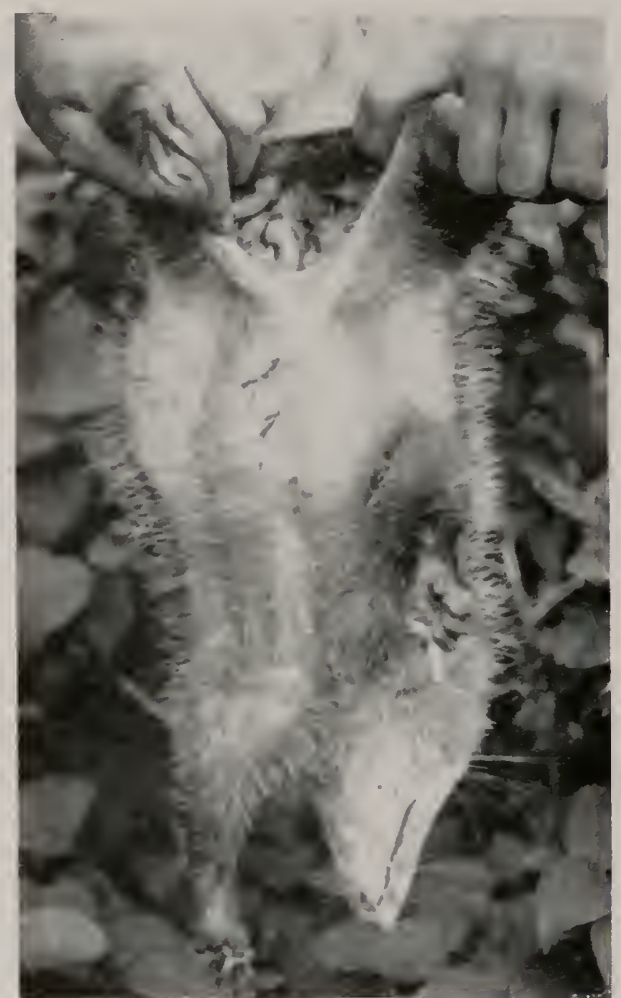

Fig. 17.-Female opossum with nine young in pouch. The young of this species are born in an immature condition and remain in the pouch for several weeks.

tion undoubtedly due to its reputed destructiveness to domestic fowls.

Damage and Control.-The objectionable characteristics of the opossum, except for the alleged destructiveness to small game, has been sufficiently indicated in the preceding paragraphs. In situations in which opossums are known to be causing damage, the writers recommend trapping as a means of control. This is a simple remedy since opossums are easily taken in any sort of baited set. Or they may be readily taken with dogs.

Populations.-In general, fur-takers interviewed reported a steady increase in opossum numbers from 1936 to 1939. when populations seemed to level off or decrease. For the two seasons covered by the surver, the actual decrease, if any, was probably less than the 30 per cent reduction indicated by the catch. The 1939-40 catch is known to have been limited by low prices and very dry weather 


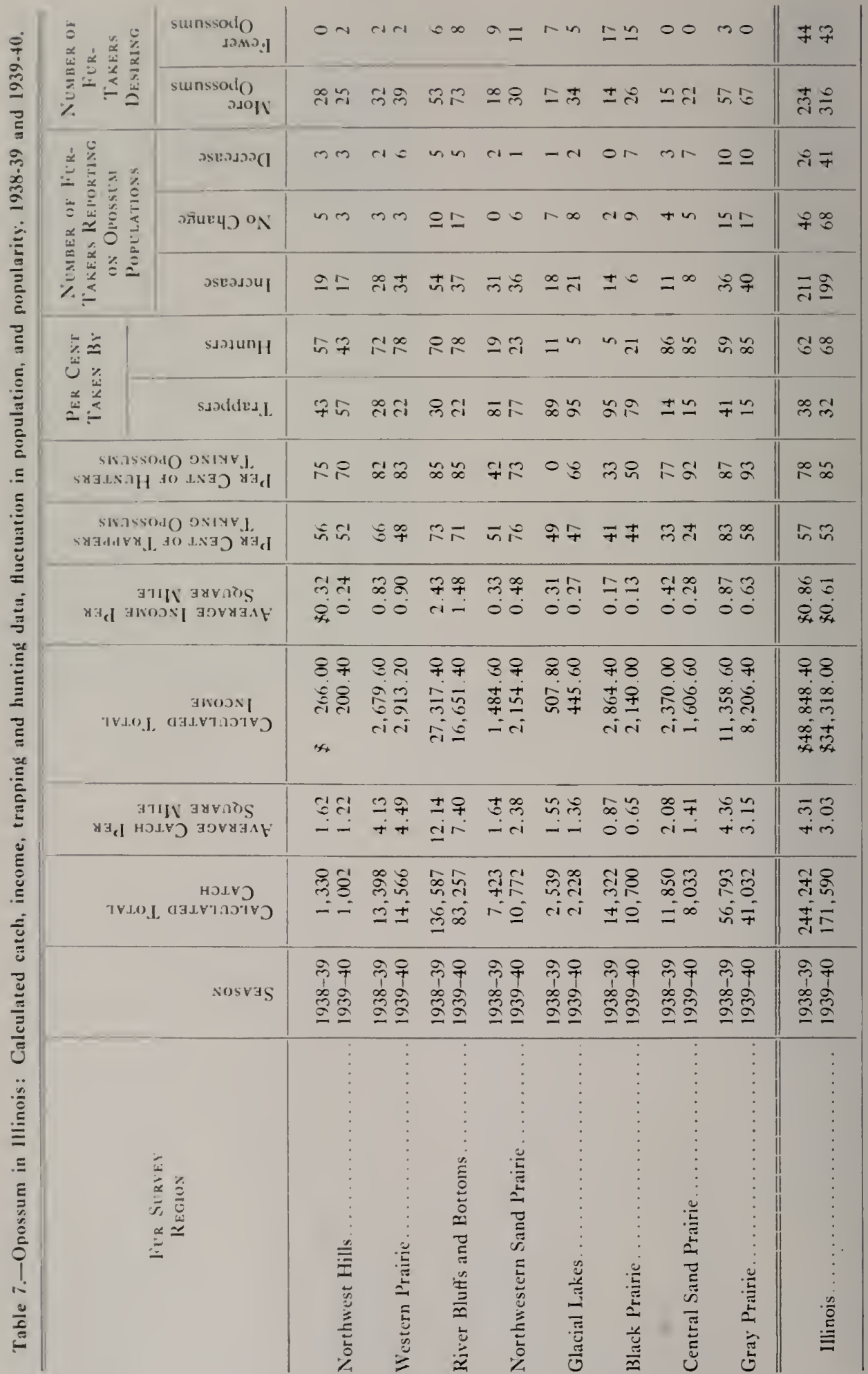


during the hunting season. Of 283 furtakers expressing an opinion on population change for 1938-39 in comparison with the preceding season, 211 reported an increase, 46 no change and 26 a decrease; for 1939-40 in comparison with the preceding season, 199 trappers reported an increase, 68 no change and 41 a decrease, table 7 . Best explaining the increase beginning about 1936 are low prices and mild winters; the possible effect of cycles was not determined.

The opossum catch ranged from 0.65 per square mile in the Black Prairie Region in 1939-40 to $12.1+$ per square mile in the River Bluffs and Bottoms Region in 1938-39, table 7. 'The more heavily wooded parts of the state are the important opossum-producing localities. 'The River Bluffs and Bottoms Region leads the other fur survey regions in the acreage of wooded areas. Next to this region in opossum catch for 1938-39 were the Gray Prairie with 4.36 per square mile and the IVestern Prairie with $t .13$ per square mile, both of which contain considerable woodland. The Central Sand Prairie with a catch of 2.08 per square mile, the Northwestern Sand Prairie with $1.6+$ and the Northwest Hills with 1.62 were next in rank in 1938-39. The Glacial Lakes with 1.55 and the Black Prairie with 0.87 ranked seventh and eighth, respectively. There was some variation by regions in rank for the season of $1939-40$, and the catch density per square mile was generally lower, table 7 .

Habitats.- The high quality of the River Bluffs and Bottoms as a habitat for opossums is at once apparent when, in addition to forest cover, the region is known to abound in bluffs and to be dotted by small irregular fields in the valleys or on the slopes. A comparatively heavy population of woodchucks provides thousands of ground dens, which, with countless tree cavities, sinkholes and small caves, supply retreats in abundance. The food supply in this region is ample and of excellent quality, with mulberries, wild grapes, brambles (Rubus spp.), pokeberries, persimmons and pecans generally abundant. Animal foods, including carrion, are also available in quantity. 'This region is less subject to fire and overgrazing than any other region except the Northwest Hills; nevertheless these two destructive practices are all too common.

Habitat conditions in the Gray Prairie, the Central Sand Prairie, the IVestern Prairie and the Northwestern Sand Prairie regions are similar in that the woodland is largely cut over. Forest cover in these four regions is most abundant in the Gray Prairie, but the water supply in this region is not dependable because of the large proportion of streams that are intermittent. 'The Northwest Hills Region generally has ample cover and water, but winters may be relatively severe. In the Glacial Lakes Region there is considerable cover in the form of wooded stream bottoms and marshy lake shores.

The Black Prairie, with the lowest acreage of woodland cover per square mile, was lowest in production of opossum furs per square mile. In this region, tree cavities are very scarce, forcing a large part of the opossum population to den underground or in debris of various sorts. Because of the level terrain and poor subsurface drainage, ground dens are easily flooded and may result in some mortality through drowning. The fact that the mother opossum carries her young in the pouch for some time after birth would seem to exclude the possibility of a very high mortality by drowning in young animals. Opossums denning in drainage tiles may suffer some drowning loss. Ground dens along ditch banks and old woodchuck holes along stream valleys and fencerows and in stripmine areas provide most of the shelter in the Black Prairie district. Natural food, which for this omnivorous species may be practically any sort of meat or fruit, is ample.

There is some evidence that opossums make use of old muskrat houses and thick growths of bulrushes and cattails along marsh areas in the northern half of the state. Wooden nest boxes erected for wood ducks are accepted as dens in both bottoms and upland areas.

Trapping and Hunting.-In Illinois, in the two survey seasons, about one-third of the annual opossum catch was taken by trappers and about two-thirds by hunters, table 7. Hunting was particularly prevalent in the Central Sand Prairie, the River Bluffs and Bottoms and the IVestern Prairie regions. It was least common in the Glacial Lakes, the Black Prairie and the Northwestern Sand Prairie. Orer one- 
half of the trappers and over two-thirds of the hunters anmually took opossums. It is apparent that opossum and raccoon hunting can be closely correlated by regions, tables 7 and 8 .

The sport of possum hunting is well known and is perhaps as popular and as widely practiced in southern Illinois as in the southern states. Unusually dry weather during the fall of 1939 over most of Illinois, followed by unusual cold, probably explains the reduction in catch for that season in all regions except the IVestern Prairie and the Northwestern Sand Prairie, where more favorable hunting conditions during the first part of the season may partiy explain the slight increase in catch over that of the preceding year.

In all regions of the state, but especially in the River Bluffs and Bottoms, Gray Prairie and Western Prairie, opossum hunters can feel reasonably certain of some sport on almost any good autumn night. In the river type region and locally in the other two regions named, it is not uncommon for a hunter or group of hunters with dogs to take a dozen or more opossums in one evening. The procedure is simple. The dog or dogs are turned loose, and the hunters wait until the "tree bark" is heard, which is usually at some small tree, but may be at a sink hole, old woodchuck den or hollow log. Dogs sometimes bay opossums on the ground, and such opossums are usually killed and sometimes destroyed by the dogs before the hunter can come upon the scene. Fur-hunters, especially during the days of high prices for opossum pelts, usually attempt to bag the catch before extensive damage is done. Opossums in trees are usually taken by shooting the animals or chopping the trees down, but sometimes simply by shaking the trees until the animals drop to the ground. Those "treed" in the ground are commonly abandoned. A persimmon grove is a favored place for taking opossums at night. In the chopping of trees, night hunters caluse a loss that is fairly common in southern lllinois.

'Trapping opossums, at least during the era of low prices, is chiefly incidental to the trapping of minks, raccoons, skunks and foxes. Many trappers resent even incidental capture, and some trappers throw. away opossums so taken. Sets, when made for opossums, are placed at the entrance of dens, on logs or at waterholes. They are usually baited, since these animals take readily almost any sort of meat foods.

Management.- Perhaps the greatest value of the opossum is the buffer effect it has on raccoon hunting. Night hunters in practically all parts of the state can depend on this species for a certain amount of sport, whereas raccoons are decidedly scarce except in the riverbottoms and forested parts of the IVestern Prairie, Northwest Hills and the Central Sand Prairie regions. Some sportsmen, interested chiefly or only in raccoon hunting, object to the abundance of opossums since it interferes with their sport.

In view of current market conditions, it is certain that the opossum is in little danger of greatly reduced numbers. Its prolificness, adaptability and omnivorous food habits enable it to withstand any likely hunting or trapping pressure. The present laws are satisfactory.

\section{Raccoon}

The raccoon is the most characteristic forest fur animal in Illinois. It is common to fairly abundant in all extensively wooded regions of the state and scarce elsewhere. The catch per square mile in the River Bluffs and Bottoms, the largest wooded region, was 1.93 raccoons in 193839 and 1.55 in 1939-40, while the catch per square mile in the Black Prairie Region, with the smallest acreage of forest cover per unit of area, was only 0.09 and 0.07 raccoon for the two seasons of the survey, table 8 .

For the season of 1938-39, the total calculated catch was 42,412 raccoons, worth $\$ 84,82+$; and in 1939-40, 34,577 raccoons, worth $\$ 69,154$, table 8 . During these two years, the value of raccoon fur was low, the average price per pelt being only about $\$ 2$, table 5 . An average value of $\$ t$ or $\$ 5$ per pelt is a more nearly normal price. The annual income from this species for the two seasons of the survey was only about $61 / 2$ per cent of the total annual worth of the fur resource in Illinois, table 20.

Popularity.-Without doubt the raccoon has wider appeal to the American public than any other furbearer, with the possible exception of the beaver. It can properly be considered the best "all 
around" fur animal, since it produces income, affords sport and food, and ranks high in aesthetic appeal. Of the Illinois fur-takers contacted concerning their opinion of the raccoon, 356 in 1938-39 and 387 in 1939-40, only 1 in each year desired fewer of these animals. Depredations by raccoons on corn and poultry are overlooked far more readily by farmers, fur-takers and non-fur-takers alike than similar activities on the part of opossums, skunks, weasels and foxes.

The sport value of raccoons, especially during an era of low prices, is probably the greatest worth of these animals in Illinois. The income value, considerably less than $\$ 100,000$ annually at the time of the survey, is probably exceeded by the yearly turnover involved in the care, training and sale of coon dogs. At price levels current when the survey was made, it is difficult for a coon hunter to take enough raccoon furs to cover the annual upkeep of his dogs. This is certainly true in cases where vaccinations, registration fees and other kennel expenses are figured in the cost.

Damage and Control.-Raccoon damage is very minor except in cornfields bordering woodlands holding sizable raccoon populations. A foray on poultry is occasionally reported, and a very few cases of injury to cultivated fruits and brambles are on record. Injury of this sort is considered too insignificant to justify control, but in instances in which it is required the writers recommend trapping, in season if possible; if not in season, the liberation of captured animals at points removed from the scene of the damage. Before trapping is attempted, Illinois State Department of Conservation investigators should be consulted and, if necessary, their aid in capture and liberation of the animals enlisted.

Populations.-On the basis of available records, and the opinion of hundreds of fur-takers, no Illinois fur animal has shown a sharper decline in numbers during recent years than the raccoon. Of 253 fur-takers expressing an opinion for the season of 1938-39 in comparison with the preceding season, 179 indicated a decrease, 41 no change and 33 an increase; for the season of 1939-40 in comparison with the preceding season, 183 trappers reported a decrease, 58 no change and 58 an increase, table 8 . In addition, many experienced fur-takers were positive in their opinions that the decrease had been steady and rapid during the preceding 5 or 10 years.

Of fur-takers reporting an increase, about 25 per cent were from the upland communities of Calhoun County, only a few miles removed from extensive bottomland clearing made in conjunction with channel improvement along the Mississippi and Illinois rivers. Such clearing forced raccoons into the nearby timbered bluffs, thus affording there a year or two of increased populations and good hunting. 'The catch in this county in 1938-39 was very high, with 2.66 raccoons per square mile. The annual catch, according to unverified but general belief among experienced hunters in this region, represented about one-half of the total population. A density of five raccoons per square mile was thus indicated for the county as a whole, the population being, of course, of even greater density on actually inhabited areas. This was the heaviest raccoon population encountered during the study.

Following completion of the survey we had numerous and apparently reliable reports of increases in raccoon numbers, noticeable particularly in $19+1$ and $19+2$. These increases are believed to have resulted from three factors that had tended to reduce the raccoon catch: low prices on raccoon furs, good agricultural crops and prices, and increased employment in industry. The additional breeding stock built up by these conditions may indeed have resulted in somewhat larger populations, despite accelerated depletion of the raccoon habitat. Such gains may be only temporary and may be easily lost during periods of good fur prices and greater than normal take.

Habitats.-It is natural that a raccoon population as high as that found in Calhoun County should occur in an excellent habitat. An abundance of heavy timber and bluffs afforded plenty of cover and dens; the water supply, consisting of large rivers, lakes, swamps, marshes and spring runs, was excellent; and extensive and widely scattered areas of brush, cultivated fields and thousands of food-producing forest trees, such as pecan and persimmon, offered ample food. Despite heavy hunting, a breeding reserve of raccoons was left because of the difficulty in removing "treed" animals from the hundreds of 


\begin{tabular}{|c|c|c|c|c|c|c|c|c|c|c|}
\hline \multirow{2}{*}{ 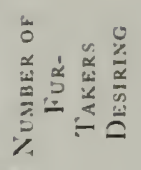 } & 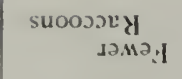 & 00 & 00 & 00 & 00 & -- & 00 & 00 & 00 & $-\rightarrow$ \\
\hline & $\begin{array}{l}\text { Suoossey } \\
\text { 2ग0II }\end{array}$ & n్ & 芦导 & $\stackrel{x}{\infty}$ & $\stackrel{\infty}{=} \mp$ & 乐京 & ते? & ते ते & $\ddot{\sigma} \pi$ & ஸூர \\
\hline \multirow{3}{*}{ 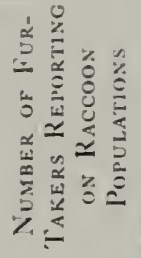 } & วऽваנगа & $\overline{2} \Omega$ & 29 & $\neq \infty$ & $\bar{\lambda}$ & Сి & n & $a 2$ & 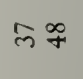 & $\stackrel{2}{2}$ \\
\hline & วลิиечว оN & $m r$ & $T-$ & $\infty=$ & NO & oin & -- & $n a$ & $\underline{2} 2$ & $\bar{F}$ \\
\hline & วระаљи I & $-\infty$ & $n \underline{0}$ & $\varrho \cong$ & $\infty N$ & 00 & $0-$ & $+\varrho$ & $n-$ & $\tilde{~} \tilde{m}$ \\
\hline \multirow{2}{*}{ 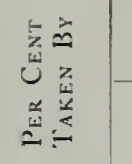 } & s.วృนn $_{H}$ & $8 \stackrel{\infty}{i}$ & लेహ & जิ尺 & bis & $=0$ & 요 & $\approx \approx$ & $8 i$ & 86 \\
\hline & sıadde. $L$ & 芦乎 & 5 in & Ғ尺 & ले & 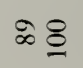 & 요요 & $r=$ & 운 & 요 \\
\hline \multicolumn{2}{|c|}{ 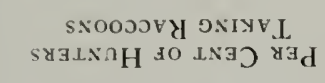 } & $\infty 8$ & 芷的 & in & 83 & $8^{\circ}$ & 요 & $ト \infty$ & $\widehat{6}$ & $\overrightarrow{6}$ \\
\hline \multicolumn{2}{|c|}{ 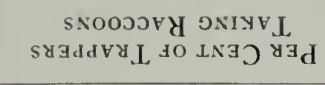 } & ते ले & 乎字 & ల $q$ & ปี & $\pm \bar{\lambda}$ & $a+$ & 92 & लैच & ते \\
\hline \multicolumn{2}{|c|}{ 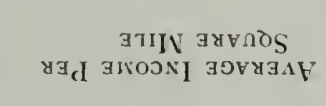 } & $\underset{\infty}{\infty} \stackrel{\infty}{0}$ & $\stackrel{\infty}{\stackrel{\infty}{i}} \underset{i}{-i}$ & $\begin{array}{l}\infty \varrho \\
\dot{m} \dot{m}\end{array}$ & $\stackrel{0}{\because}$ & 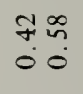 & $\frac{\infty}{0}:$ & 면 & 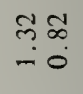 & ำ \\
\hline \multicolumn{2}{|c|}{ 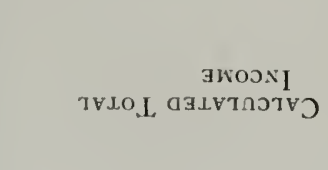 } & 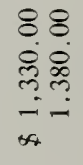 & $\begin{array}{l}88 \\
80 \\
\text { i̊ } \\
\text { nin }\end{array}$ & \begin{tabular}{l}
88 \\
$8 \infty$ \\
$\infty$ \\
\multirow{1}{*}{$\infty$} \\
\multirow{7}{*}{$\dot{m}$}
\end{tabular} & $\begin{array}{l}88 \\
\infty \\
\infty \\
5 \\
5 \infty \\
+\infty \\
+\infty\end{array}$ & $\begin{array}{l}8,8 \\
\infty \\
\infty \\
0 \\
0\end{array}$ & 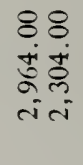 & 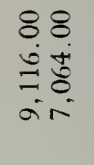 & $\begin{array}{l}88 \\
80 \\
50 \\
0 \\
=0\end{array}$ & 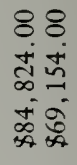 \\
\hline \multicolumn{2}{|c|}{ 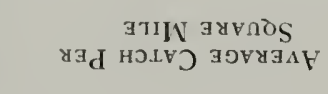 } & $\begin{array}{ll}\bar{\infty} & + \\
0 & 0 \\
0 & 0\end{array}$ & $\begin{array}{l}9 \% \\
0 \\
0\end{array}$ & $2 \tilde{2}$ & 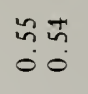 & तथ & $\begin{array}{l}80 \\
00 \\
0\end{array}$ & 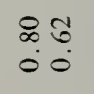 & $\begin{array}{l}07 \\
0\end{array}$ & $\begin{array}{l}\approx 0 \\
00 \\
0\end{array}$ \\
\hline \multicolumn{2}{|c|}{$\begin{array}{c}\text { HOLVว } \\
\text { TY.LOL बร.LVTกวTVว }\end{array}$} & 댕 & $\begin{array}{l}3.5 \\
\text { B己 } \\
\text { in } \\
\text { in }\end{array}$ & $\begin{array}{l}\text { से } \\
\text { ì }\end{array}$ & 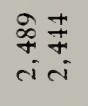 & 苦等 & 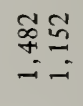 & 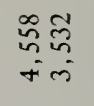 & 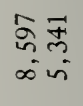 & 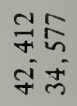 \\
\hline \multirow{2}{*}{\multicolumn{2}{|c|}{ 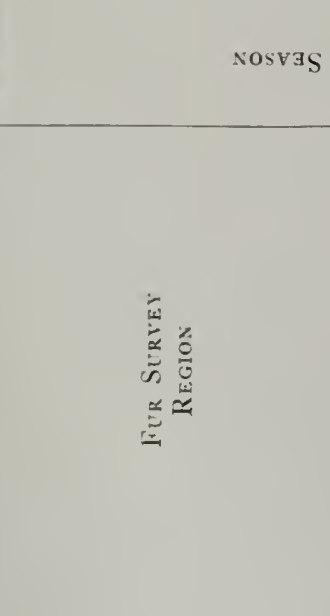 }} & 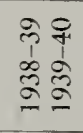 & 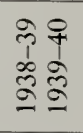 & 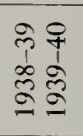 & $\begin{array}{l}90 \\
11 \\
\infty \\
\tilde{2} \approx \\
0\end{array}$ & $\begin{array}{l}0 \\
\hat{1} \\
\infty \\
0 \\
0 \\
0\end{array}$ & 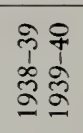 & 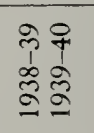 & 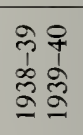 & 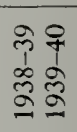 \\
\hline & & 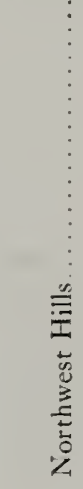 & 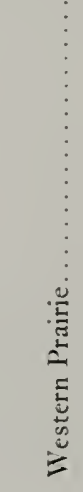 & 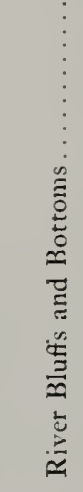 & 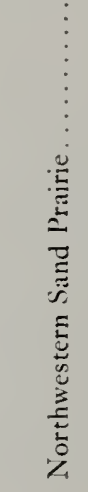 & 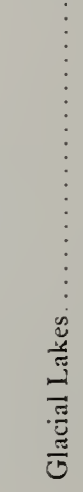 & 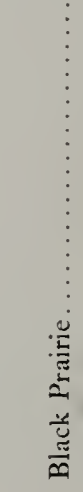 & 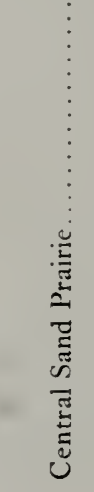 & 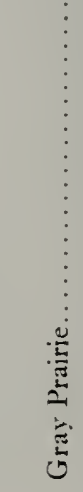 & $\begin{array}{c}\vdots \\
\vdots \\
\vdots \\
\vdots \\
\vdots\end{array}$ \\
\hline
\end{tabular}


cares and sinkholes in the bluffs. As stated, recent clearing in Calhoun County disturbed the raccoon population there and seems to have resulted in a total larger catch, as well as a reduction in habitable range (Yeager \& Rennels 19+3). The raccoon, figs. 6,18 , and 22 . Among possible den sites, tree cavities rank highest with this species. Rock or ground cavities may be used, but where timber is present they are generally passed up except as escape cover. The opossum readily dens in

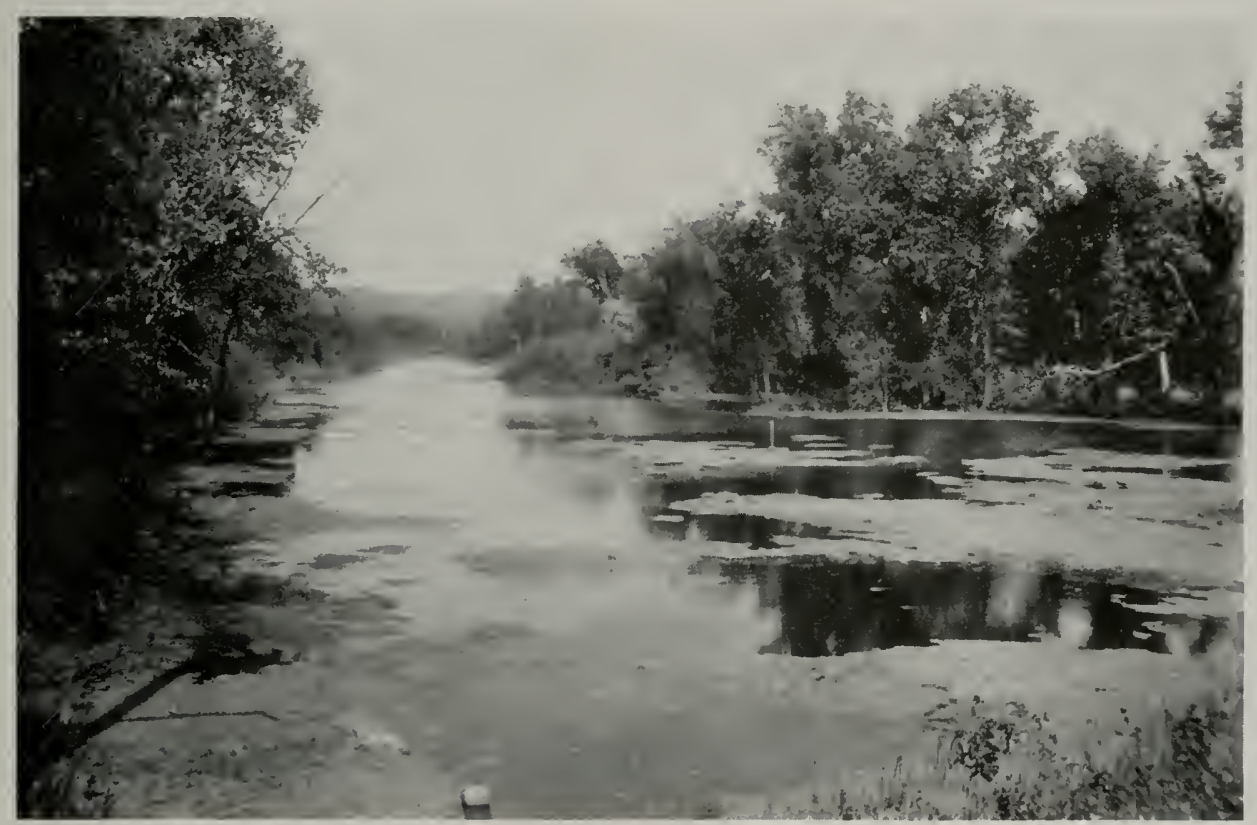

Fig. 18.-Big Slough, Pere Marquette Wildlife Area, Calhoun County. The riverbottom type shown here is probably optimum for raccoons.

river bluffs and bottomland habitat, generally, is now gradually being depleted by timber cutting, overgrazing, fire and erosion.

In table 9 an attempt is made to evaluate the influence of forest cover, grazing and water on the several types of raccoon habitats in the state, as reflected in the catch per square mile.

It is apparent that there is some correlation between raccoon numbers and the proportion of woodland in given regions, but the influence of woodland may be affected by various other factors. $I \bar{V}$ ater is believed to be the most important of these. Grazing, fire, maturity of woodland and other conditions have some effect, undetermined in this study.

The raccoon does not possess to the same degree the opossum's adaptability to a wide variety of habitats. Forest cover and a plentiful water supply appear to be more or less inflexible requirements of the the ground, even in the vicinity of tree carities (Yeager 1936).

The Northwest Hills Region affords excellent raccoon cover, both forest and bluff, but much of the wooded area is too far from water to be of high attractiveness. Water, except along the Mississippi River, is in the form of small, steepbanked streams. There are few heavily wooded swamps or large riverbottoms, which appear to furnish the best type of raccoon habitat. Pelts from this region are dark and well furred, a high percentage of them grading as "collar" raccoon.

The Western Prairie, Central Sand Prairie, Northwestern Sand Prairie and the Glacial Lakes regions are alike in that water is generally available. 'This consists of streams, marshes and sizable lakes, and along the lllinois River a very limited amount of wooded swamp. The degree of grazing varies widely, being especially heavy in the Northwestern Sand Prairie, 
the Glacial Lakes and the Western Prairie regions. Many of the shallow, marshbordered lakes in the Glacial Lakes Region are some distance from forest cover, is fact which may partially explain the low raccoon population there. In all of these regions, the woodland has largely tent nature of many of the streams and ditches. Food, as in all other regions, is probably ample, although it falls far short of the variety and, except in corn, of the quantity found in riverbottoms.

The severe shortage of dens throughout the prairie districts is indicated by the use

Table 9.-Effect of forest cover, grazing and water on Illinois raccoon habitats, as reflected in the calculated raccoon catch per square mile.

\begin{tabular}{|c|c|c|c|c|}
\hline \multirow[t]{2}{*}{ Fur Survey Region } & \multicolumn{2}{|c|}{$\begin{array}{l}\text { Per Cent of } \\
\text { Region in } \\
\text { Woodland* }\end{array}$} & \multirow{2}{*}{$\begin{array}{c}\text { Water Resources } \\
\text { (IN Relation to Suitability } \\
\text { to Raccoons) }\end{array}$} & \multirow{2}{*}{$\begin{array}{c}\text { Raccoon } \\
\text { Catch } \\
\text { Per SQUare } \\
\text { Mile, } \\
1938-39 \\
1939-40\end{array}$} \\
\hline & Total & Ungrazed & & \\
\hline River Bluffs and Bottoms & 24 & 13.0 & $\begin{array}{l}\text { Excellent: } \text { Large rivers, creeks, lakes, } \\
\text { swamps, marshes................ }\end{array}$ & 1.74 \\
\hline Western Prairie. & 11 & 1.0 & 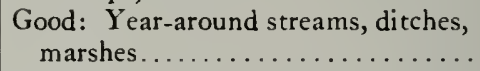 & 0.94 \\
\hline Northwest Hills. & 17 & 1.0 & $\begin{array}{l}\text { Good: Year-around streams, spring } \\
\text { runs } \ldots \ldots \ldots \ldots \ldots \ldots \ldots \ldots \ldots\end{array}$ & 0.83 \\
\hline $\begin{array}{l}\text { Central Sand Prairie.. } \\
\text { Northwestern }\end{array}$ & 6 & 4.0 & Good: Streams, ditches, marshes.... & 0.71 \\
\hline Sand Prairie. & 3 & 0.3 & 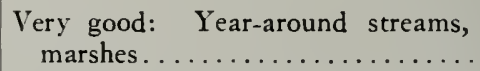 & 0.55 \\
\hline $\begin{array}{l}\text { Gray Prairie. . } \\
\text { Glacial Lakes. }\end{array}$ & $\begin{array}{l}7 \\
7\end{array}$ & $\begin{array}{l}4.0 \\
0.6\end{array}$ & $\begin{array}{l}\text { Poor: Small, intermittent streams... } \\
\text { Good: Lakes and marshes, some }\end{array}$ & 0.54 \\
\hline Black Prairie. & 2 & 0.1 & $\begin{array}{l}\text { streams } \ldots \ldots \ldots \ldots \ldots \ldots \ldots \ldots \\
\text { Poor: Intermittent streams and } \\
\text { ditches } \ldots \ldots \ldots \ldots \ldots \ldots \ldots \ldots\end{array}$ & $\begin{array}{l}0.25 \\
0.08\end{array}$ \\
\hline
\end{tabular}

*U. S. Department of Commerce, Bureau of the Census, Agriculture-Illinois, 1935, pp. 9-15. Percentage figures calculated from data given on grazed and ungrazed woodland, by counties; based only on sample counties.

been cut over, resulting in the loss of a large percentage of the den trees.

In the Gray Prairie Region, comparatively large timbered areas occur, but den trees are scarce because of long-continued lumbering operations, and also because many den trees have been cut by hunters and others. There are few bluffs in this region suitable as raccoon retreats. Water, supplied chiefly by small, intermittent streams, is scarce and undependable. Pasturing of woodlands, because of their comparatively large area, is not so heavy as in the Northwest Hills, the Glacial Lakes or some other regions.

The large Black Prairie Region offers the poorest raccoon habitat in the state. It is acutely short of forest cover, and practically all of the woodland is pastured. It contains few bluffs suitable for ground dens. WVater is scarce and undependable over this prairie because of the intermit- made of muskrat houses. On three occasions, the authors found hibernating raccoons using muskrat houses and evidence of such use on many other occasions. Trappers along the Illinois River often reported use by raccoons of muskrat houses, and even of thick tangles of bulrushes, both as hibernating and overnight retreats.

Trapping and Hunting.-In Illinois in the two seasons of the survey, about two-fifths of the annual catch of raccoons was made by trappers and about threefifths by hunters, table 8 . Hunting was especially prevalent in the Central Sand Prairie, the River Bluffs and Bottoms, the Northwest Hills, the Gray Prairie and the Northwestern Sand Prairie regions. Trapping was the chief means of capture in the other regions; coon hunting apparently was practiced very little in the Glacial Lakes Region. 


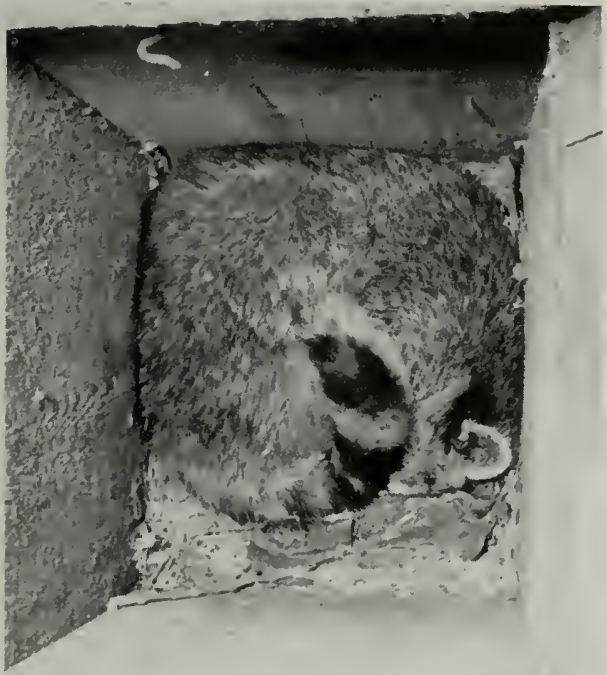

Fig. 19.-Raccoons accept artificial dens if the dimensions and location are satisfactory. The best locations are probably near water. The raccoon shown here is at the bottom of a den box placed in the Urbana Township Wildlife Area, Champaign County.

Coon hunting is a night sport too well publicized to require lengthy discussion here. The writers desire only to mention that a sizable business is represented in the coon dog breeding and training industry, and that coon hunters in general pursue the sport more for the pleasure it affords than hope of pecuniary reward. This was true especially during the era of low prices in which the survey was made. Hunters, in order to perpetuate their sport, to say nothing of the resource, should refrain from cutting den trees or timber of any sort; there seems to be a growing sentiment to this effect. Very cold or very dry weather tends to make poor coon hunting; the severe drought followed by cold weather and deep snow in 1939-40 may account in part for the reduced raccoon catch for that season.

The scarcity of raccoons has caused numerous coon-hunting clubs, especially in the northern part of Illinois, to demand restocking by the state. In response, the Illinois State Department of Conservation in 1939, at its game farm near Mount Vernon, began artificial propagation of this species.
Raccoons are trapped in both baited and nonbaited or "blind" sets, usually in water. Fish, rabbit and similar meat attractors are commonly used. Traps set on logs, particularly in the vicinity of water, are usually productive. Den sets are not common, due to their inaccessibility. A strong trap, such as the No. 2, is needed because the raccoon possesses great strength and makes a courageous fight for freedom. Confirmed coon hunters are apt to look upon trapping as unsportsmanlike, and feel that trappers encroach upon their sport. In Illinois, especially in the southern half of the state, there is considerable dissention between coon hunters and trappers.

Management.-The most obvious need in restoring raccoon population is an improved habitat. This, when it involves the production of tree cavities, becomes a long-time program. Very desirable steps in restoring forest cover are being taken by the Illinois State Division of Forestry, the U. S. Forest Service and the U. S. Soil Conservation Service. To be most valuable to raccoons, plantings should be of hardwoods and located in the vicinity of water.

Cutting of den trees should be stopped. In localities where bluffs do not occur, and the topography is too flat and the soil too poorly drained to permit satisfactory ground denning, there is no practice more destructive to present and future raccoon populations than den-tree cutting. It should be remembered that 40 to 60 years are required to grow a den tree, even on good sites and with rapidly growing species such as soft maple. Conditions unsuitable to ground denning exist throughout the prairie regions, including most of the stream bottoms.

The utility of artificial dens has not been adequately studied, but the writers feel that they may have an important place in management, fig. 19. For example, if a practical and satisfactory den box can be developed, young timber stands that are in the vicinity of water but that lack natural cavities could be turned into productive habitats. Acceptable boxes should have minimum inside dimensions of 12 by 15 inches. The entrance hole should be 6 inches in diameter and the cavity at least 3 feet deep. Such boxes made in quantity from No. 1 cypress 
lumber would cost probably \$2 each; if constructed from state-owned timber they could be made at a lower cost. Good cypress den boxes, with some maintenance, would last at least 10 years, giving an annual cost of 20 cents each, plus upkeep expense. Artificial dens should be erected well off roads, substantially fastened in or above the first crotch of the largest trees available, and probably they should be placed near water. A box design bringing the entrance hole close to the tree trunk permits easy access.

Boxes similar to the raccoon den just described are known to be readily used by opossums, squirrels and certain cavitynesting birds. Such boxes on the Urbana Township IVildlife Area are being used by raccoons; the closest timber is about 2 miles away. Honeybees and other insects also make appreciable use of these boxes. Work necessitated by pre-emption of these forms would be a major item of the maintenance cost. If this and similar work could be done by sportsmen's clubs, upkeep cost would be low.

Raccoon laws, in view of the conflicting interests of hunters and trappers, are difficult to formulate. The writers believe that, as a principle, the enactment of laws favoring either of the groups at the expense of the other would be unwise, and that both groups have rights that should be considered in laws regulating capture of this popular species. Trappers, in general, take the animals as a means of livelihood; hunters, in general, take them as a means of sport. Since it is obviously impossible to satisfy completely both groups, we recommend a uniform trapping and fur-hunting season on all species, opening Dec. 1 and closing Jan. 31. It is realized that the raccoon season opening Dec. 1 would operate against both hunters and trappers, because raccoons hibernate during cold weather which often comes, especially in northern Illinois, during December. However, the present low raccoon population justifies a reduced catch, and in time this season would benefit both groups.

The summer training of coon dogs is another delicate, but rather important, point in the making of raccoon regulations. 'The writers are of the opinion that any disturbance of raccoons, such as that caused by summer training, is undesirable if only the welfare of the species is considered.
However, coon dog breeders and trainers have a considerable investment, and the business provides a livelihood, wholly or in part, for several hundred people in the state. Just laws should take these facts into consideration. The 1941-42 law permitted the hunting of raccoons for the purpose of dog training from Aug. 15 through March 31. We believe that, for the best interests of all concerned, these dates should be changed to Sept. 15 and Jan. 31, since the first date would permit young raccoons to attain greater size and maturity, and the second would largely prevent interference with breeding, as is possible under the March 31 closing law. Even the law as proposed has one bad feature, that of tempting hunters to take illegally more or less prime furs from the first of November until the season opens. An alternative is to close this period to dog training.

Raccoons are commonly taken in traps set for almost any Illinois furbearer, a condition that precludes practical trapping laws favoring this species, even if such laws were fair and desirable. It would, of course, be possible to close the entire state or given parts thereof to all coon hunting and trapping for a year or two, with provisions for releasing raccoons unavoidably taken in traps. Such a law would involve complications in law enforcement, in the release of severely injured animals, and in the utilization or waste of raccoons drowned after being taken in traps. At best this law is in the category of "last resort." It would be far more desirable to institute a vigorous campaign of habitat restoration involving protection of den trees, erection of artificial dens, development of water resources, protection of areas against fire and overgrazing and, where needed, liberation of a moderate number of artificially reared raccoons. These provisions, plus the shortened trapping and dog training seasons proposed, should offer a slow but effective means of restoring naturally both the population and the habitat.

The effectiveness of complete protection of raccoons on given areas as a restoration measure should not go unmentioned. The writers know of three areas in which little management other than complete protection has resulted in the building up of very high raccoon populations. These 
areas are the Chautauqua National IVildlife Refuge in Mason County, the Horseshoe Lake Game Refuge in Alexander County and the U. S. Army Proving Grounds in Carroll County. All are riverbottom types in proximity to water. Protection in these areas has extended over a period of 10 years or more, and on all there is now need for the removal of a part of the raccoon population in order to prevent overcrowding.

\section{Skunk}

The taxonomic status of skunks in Illinois has never been satisfactorily determined (Anthony 1928, Hall 1936, Gregory 1936, and Necker \& Hatfield 19+1). Whatever their systematic position, for purposes of this survey striped skunks have been grouped under Mephitis mephitis. The spotted skunk, Spilogale, apparently does not occur in the state.

Striped skunks are rather generally distributed throughout Illinois. For the season of 1938-39, the total calculated catch was $49,6+0$, worth $\$ 37,230$; and in 1939 t0 the calculated catch was 36,681 , worth $\$ 36,681$, table 10 . During the two seasons covered by the study, skunk prices were low, the average being 75 cents for the first year and $\$ 1$ for the second, table 5 . The normal value is nearly twice as much. In catch value, skunks ranked fifth among Illinois fur animals, with slightly more than 3 per cent of the total, table 20. The true value of the species, however, is determined only by evaluating its insect-eating proclivities and adding this value to fur income worth.

Popularity.-In Illinois only the red fox appears to have a position more variable in public esteem than the skunk. One farmer may consider a family of harndwelling skunks good insurance against rats and mice; and his neighbor may condemn them because of actual or assumed injury to poultry. Many orchardists in southern and southwestern Illinois protect skunks because of their services as mousers and insect eaters, while sportsmen in the same regions demand control of these animals in the interest of game birds. Of $60 t$ answers received as to fur-takers' opinions of skunks, 35 favored fewer of the animals, table 10. Only the opossum ranked lower in favor as a fur species, and only the weasel had a lower rating in general public opinion.

Damage and Control.-Skunks are objectionable more from the standpoint of nuisance than actual damage to property. Their nuisance quotient probably reaches its zenith when they den under dwellings or farm outbuildings, which they not infrequently do. Farm dogs inevitably run afoul of farmstead skunks, and the results can be detected from afar. Most such skunks, with some justification, are not reserved until the winter fur harvest.

Damage by skunks to beehives, lawns and pastures, all in quest of insect food, is commonly reported. Although damage to beehives represents an actual loss, the digging of grubs and other insects almost certainly prevents greater injury to grass and field crops. Occasional to habitual destruction of poultry is perhaps the worst offense of which skunks are guilty. Habitual depredation is usually confined to individual animals, the elimination of which affords ample control. Because skunks are poor climbers, their injury to nests and eggs is confined to ground-frequenting birds.

Skunk control has recently heen well discussed by Green \& Mills (1941). Where practicahle, trapping with No. 1 or No. $11 / 2$ traps during the fur season is the most desirable control, since the animals can then be made to yield a cash income. Skunks are easily trapped in trails, coop entrances, passageways through fences or at baited sets in the vicinity of their dens. They are also easily taken in box traps, in which they may be drowned before being removed. In tight box traps or similar containers they may be killed quickly, and without unpleasantness to the killer, with carbon hisulphide, ether or chloroform. Shooting with a small rifle is probably the most practical way to kill trapped skunks, but this method does not insure against "scenting." IVe consider widescale control of skunks in the interest of upland game or for similar purposes to be inadvisable at any time.

Populations.-In the two seasons of the survey, the annual skunk catch showed more change by regions than that of any other important fur animal. The state as a whole showed a decrease in catch for the second year of about 26 per cent, table 10 , despite a $33 \frac{1}{3}$ per cent increase in 


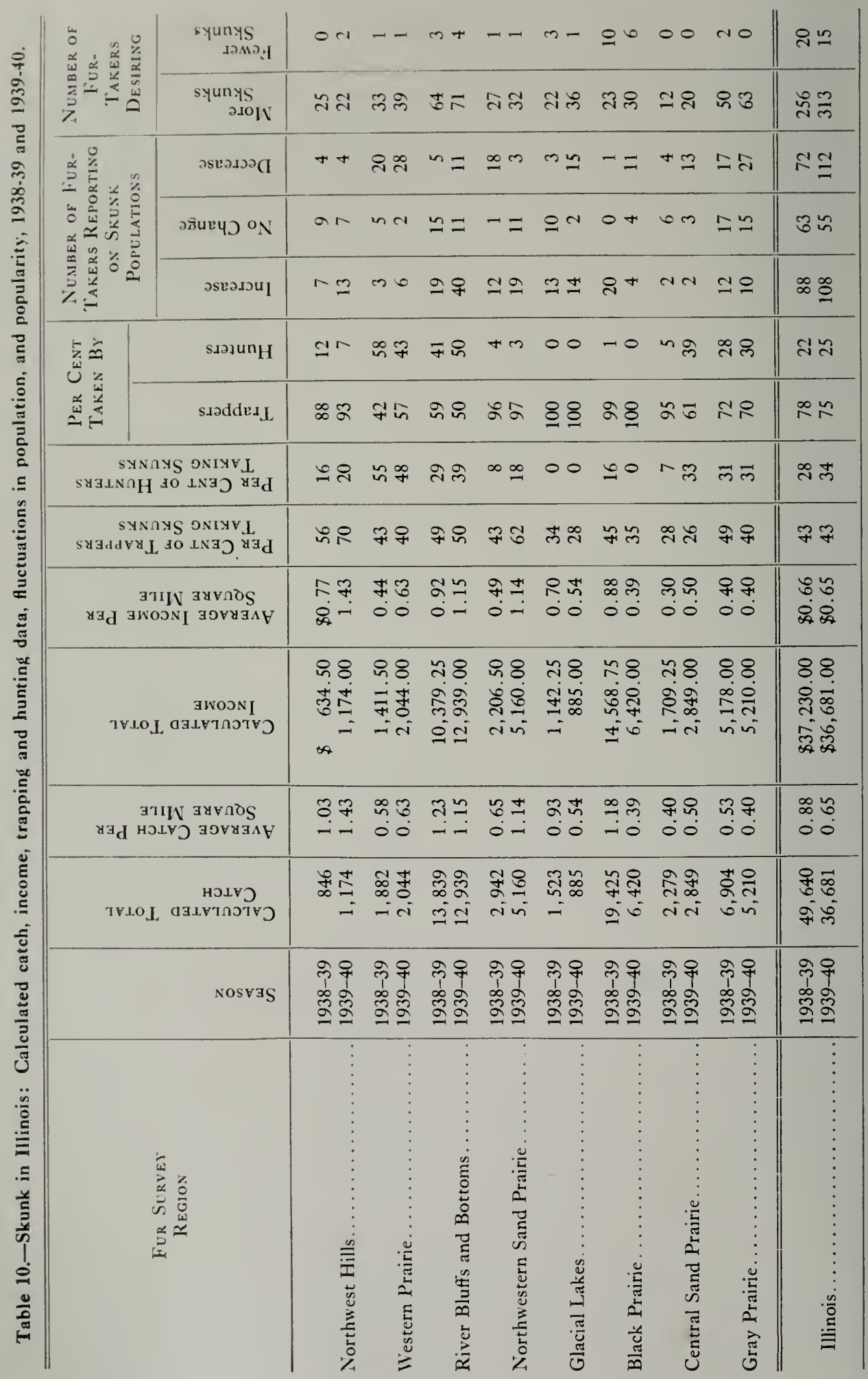


market price of the fur, table 5. This condition strongly suggests a substantial decrease in the population. Four regions showed a decline in catch. 'The Black Prairie, with a catch decreasing from $19,+25$ to $6,+20$, absorbed most of the loss. This is a decline of nearly 70 per cent. The Glacial Lakes Region showed a decline of about 50 per cent, and the Gray Prairie a decline of less than 25 per cent. An increase over the 1938-39 catch occurred in four regions; the increase was most pronounced in the Northwestern Sand Prairie, where it amounted to over 75 per cent. Thus, losses occurred in the northeastern, central, and southern parts of Illinois, and gains in the central west and northwest. We are unable to explain these population trends and changes.

Quantitatively, the catch varied from a 2-year average of 0.45 skunk per square mile in the Central Sand Prairie and 0.47 per square mile in the Gray Prairie to 1.19 per square mile in the River Bluffs and Bottoms and 1.23 per square mile in the Northwest Hills. The average catch for the state was 0.88 per square mile in $1938-39$ and 0.65 per square mile in 1939-40, table 10.

Fur-takers' opinion of population fluctuation was divided. In 1938-39, 88 of the persons questioned believed there had been an increase over the previous year, 63 no change and 72 a decrease; in 193940,108 reported an increase over the previous year, 55 no change and 112 a decrease. Many experienced trappers reported that the skunk population in the Black Prairie belt a year or two prior to 1938 had dropped to a very low level. If this report is true, a quick build-up necessarily had occurred to make possible a catch of 1.18 per square mile for the season of 1938-39. The fact that the catch dropped to 0.39 per square mile the following season, despite higher prices, indicates that sudden and violent fluctuations in density may occur in this species.

Disease seems to be the only available explanation of such great changes in skunk numbers, but what disease and how it works is unknown. The fluctuation is strongly suggestive of cyclic behavior. In several sample counties, trappers reported the finding of dead or paralyzed skunks in the field. Of three skunks examined by the writers, one had died of injuries inflicted by an automobile, and one from the combined effects of exposure and infection due to the loss of a front foot, probably in a trap; the third, taken in a barn lot, was rabid. A partial explanation of the fluctuation may lie in extensive woodchuck gassing campaigns and the depredations of hundreds of free-ranging dogs, especially in the southern half of Illinois. Neither factor, nor the combination of the two, can account for the suddenness and the degree of downward fluctuation apparent on the Black Prairie where gassing was most common. Even if they could account for the decrease, their absence could scarcely be responsible for the almost equally well-marked buildup in the population noted in 1939-40 in the Northwestern Sand Prairie. Disease, or the operation of a cycle, remains as the most logical explanation.

Habitats.-Scarcity of suitable cover, range and denning sites constitutes the chief shortcomings of 11 linois skunk habitats. A shortage of water may be an additional problem in the Gray Prairie and Black Prairie regions. Food in the form of insects, mice, amphibians and carrion is undoubtedly ample in all regions; and the food problem is further reduced because of hibernation during severe weather when most of the above foods are difficult to obtain.

The characteristics of a good skunk habitation are not precisely known, but since the largest Illinois catches are made in rolling or bluff country, in which mixed farming is practiced, figs. 5 and 25 , and where there is a considerable area of timber and pasture land with good water resources, it can be assumed that these Iocalities offer the best habitats in the state. 'The Gray Prairie Region, which showed one of the lowest vields, has some of the same characteristics; but water is scarce there and undependable, bluffs are lacking, and more of the region is subject to burning. The function of bluffs may be important, since skunks living or hiding in them are protected against den destruction (now illegal); such protection, perhaps, results in a larger breeding reserve. The use of woodchuck holes, especially for hibernating, is very common among skunks. Occasionally hollow trees or stumps are so utilized, fig. 20. The Gray Prairie Region, as well as the Northwest 
Hills, contains many logged-over and uncultivated areats devoted to grazing or urcharding which afford fair skunk range.

'lopographic and soil conditions in the Black Prairie Region are particularly unfavorahle for ground dens. Of this region, probably less than 5 per cent, chiefly in the form of stream banks, satisfactorily meets the requirements of drainage and concealment for ground-denning mammals such as woudchucks and skunks. Heavy rains during the spring of 1939 and $19+3$ maly have resulted in some skunk mortality, especially of young, through drowning. Throughout the Black Prairie, skunks den along ditch banks, tile drains, or under woodpiles or farm buildings. The various sand and other prairie regions of the state are rolling enough to afford good grounddenning sites.

Trapping and Hunting.-Its slow movements and characteristic defense disqualify the skunk as a sporting species. Most of the skunks taken by hunters are captured incidentally to raccoon, opossum and mink hunting. About 20 per cent of the total catch is taken by hunters, and only ahout one out of five hunters is fortunate-or unfortunate-enough to capture them even incidentally. A very few hunters who specialize in skunks were encountered during the survey, chiefly in the Western Prairie and the River Bluffs and Bottoms regions. Practically no skunk hunting is done in the Glacial Lakes or Black Prairie regions.

'I'rappers, alway's strongly influenced by prices, were comparatively indifferent toward skunks. A large part of the catch was taken in connection with raccoon, fox and mink trapping. However, where skunks were numerous, and especially when a series of dens was located, trappers made deliberate efforts to take them. Serious skunk trapping is most common in the Northwest Hills, where the first weeks of the season are devoted to muskrats and minks; after the formation of ice, traps are moved to the uplands for skunks and foxes. Even in this region, trappers whose regular business calls for meeting the public avoid skunks and quickly dispose of those taken in sets made for other animals.

Management.--In view of the general though thin distribution of skunks in Illinois, the problems imposed by the

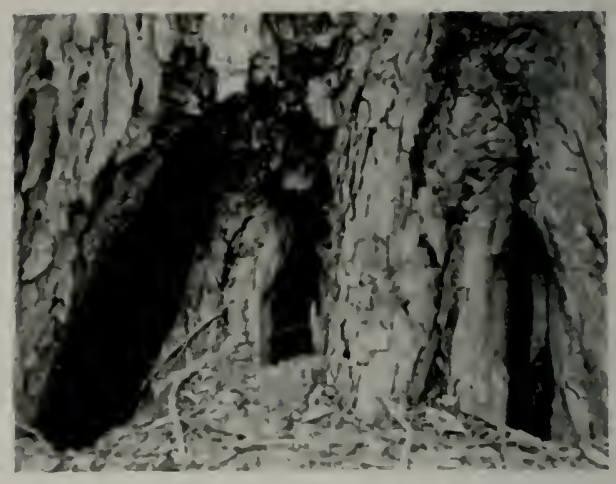

Fig. 20.-Skunk den in base of overmature white elm, Pere Marquette Wildlife Area, Calhoun County.

cyclic-like behavior of the species and the ease with which the animals are taken in any sort of upland set, we have no specific recommendations for management. It ap)pears most practical to continue to list skunks with other fur animals and to subject them to the same open season. 'The public, farmers and sportsmen especially, should realize that the skunk is one of the most valuable rodent and insect controls. We are opposed to large-scale control of this species in the interest of game or poultry. We endorse land use leading toward the reforestation and protection of stream banks and other areas not suited to cultivation. Such a policy should ultimately result in more wildlife habitats, from which skunks would benefit.

\section{Mink}

Two subspecies of minks occur in Illinois, the common mink and Mississippi valley mink (Necker \& Hatfield 19+1). The ranges of the two overlap, but the former has the more southerly distribution. The common mink is slightly smaller and darker than the other subspecies.

Minks, like skunks, are generally distributed over Illinois; the density of population appears to parallel muskrat numbers and the amount of permanent water. For the season of 1938-39 the total calculated catch was 53,723 , worth $\$ 376,061$; and in 1939-40, $45,25+$, worth $\$ 271,524$, table 11. The take of the second year shows a decline of about 16 per cent from that of the first. The decline in value was somewhat more, since the average price 
per pelt dropped from $\$ 7$ for 1938-39 to $\$ 6$ for 1939-40, table 5. Even after the drop in price, the mink remains, per pelt, the most valuable fur animal now occurring in the state. These prices may be considered low, in view of a value of nearly twice as much during a part of the previous decade. Minks, with about $t$ per cent of the total number of fur animals pelted, ranked third in the catch for the two seasons of the survey, table 20 .

Popularity.-Among trappers the mink is even more popular than the muskrat, although the difference is slight. These two species constituted over 72 per cent of the anmual catch and over $8+$ per cent of the annual value of all Illinois raw furs for the seasons of the surver, table 20. As would be expected, the popularity of minks among non-fur-takers is not so high, since by many farmers and sportsmen the species is considered in the light of its occasional depredation on poultry and game birds. Out of a total of 718 answers from fur-takers in regard to opinion of minks, only 8 favored fewer of these animals, and it is probably significant that 7 of the 8 answers were from the Black Prairie and Glacial Lakes regions, in parts of which poultry raising and hunting pressure are maximum for the state. It is safe to say that minks rank higher than opossums, weasels and skunks in general public esteem.

Damage and Control.-The chief damage caused by minks has been indicated. Individual minks may indeed be destructive; we have a number of recent reports to this effect. Individual minks have been known to kill a dozen or more chickens in one night. Perhaps the greatest economic loss caused by the species is to muskrats. Dearborn (1932) found that in southern Michigan about onefourth of the winter food of minks consisted of muskrats, which are also part of the summer diet, but the proportion is probably lower because of the greater availability in summer of other warmhlooded prey. A number of trappers along the 1llinois River, and one manager of a 2,600-acre duck club and muskrat ranch, reported that they killed minks at every opportunity throughout the year. This club manager reported finding 13 freshly killed muskrats, 2 mallards and a coot in one mink den. The muskrats were sold for $\$ 1.90$ each and the mink pelt for $\$ 12.50$ (Yeager 19+3a).

Trapping is recommended as the best means of mink control. Minks, quite properly considered intelligent mammals, are rather easily taken in both trail and baited sets. Because of the high value of the furs, we strongly recommend that, where possible, control be postponed until the winter months. In the event that control at other seasons is necessary, release of trapped animals at points where damage is not likely to occur may well result in a future income of several dollars per mink.

Populations. - The annual mink catch for the period covered by the survey indicates considerable variation in population density by regions. The take of $0.95 \mathrm{mink}$ per square mile in 1938-39 and 0.80 per square mile in 1939-40 represents a reduction of about 16 per cent; for muskrats the reduction in take during the same period was about 25 per cent ; for opossums. 30 per cent; raccoons, 19 per cent; and skunks, 26 per cent. The reduction of 14 per cent in the value of mink pelts in 1939-40, table 5, does not explain the reduction in catch, since any animal worth an average of $\$ 6$ each, and which is as small and as easily handled as the mink, is captured by fur-takers at every opportunity. Practically all experienced trappers interviewed were of the opinion that a steady decline in mink populations had been in progress for several years. Of the trappers expressing an opinion on the catch for 1938-39 as compared with that for the previous year, 55 reported an increase, $6 t$ no change and 112 a decrease; for the season of 1939-40, 55 reported an increase, $6+$ no change and 156 a decline, table 11 .

The Glacial Lakes Region, with 2.69 and 2.76 pelts per square mile for the two seasons of the survey, showed by far the heaviest mink catches. 'The River Bluffs and Bottoms Region was second, with catches of 1.70 and 1.20 minks per square mile. The Western Prairie (0.92 and 1.22), Northwest Hills (0.87 and 0.91), the Gray Prairie (0.99 and 0.78), Northwestern Sand Prairie (0.71 and 0.97), Black Prairie (0.52 and 0.36) and the Central Sand Prairie (0.32 and 0.36) followed in this order, table 11 . In the second season as compared with the first, 


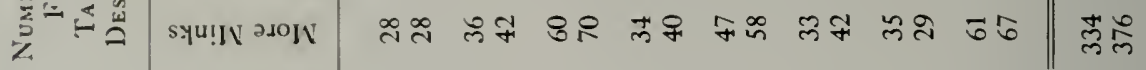

\begin{tabular}{|c|c|c|c|c|c|c|c|c|c|c|c|}
\hline$\stackrel{0}{2} \sum_{n}^{2}$ & วธгวлวа & $2=$ & ㅇ: & & $\sqrt{2}$ & $\simeq \simeq$ & $\stackrel{\infty}{=}$ & $=\varepsilon$ & & $0 \simeq$ & $=$ \\
\hline
\end{tabular}

能空至

$\alpha \simeq 2$

w

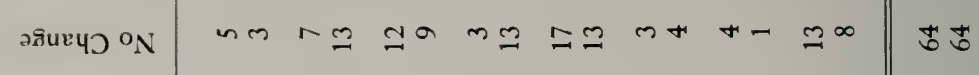
خ.

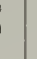

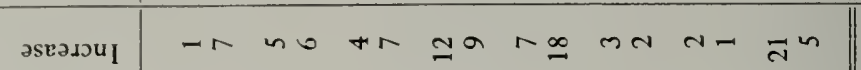

点昆

U⿺辶,

(19)

r.

sıวนก

o

न

$\approx n$

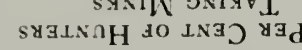

¿요

SYNIT DNITH

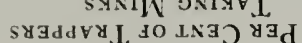

उาाก उมชภos

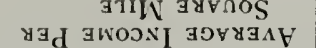

○0 ฝี

4⿻

(1)

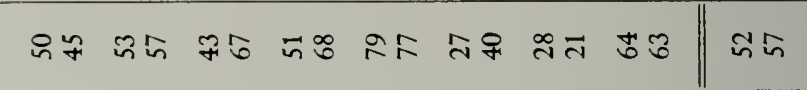

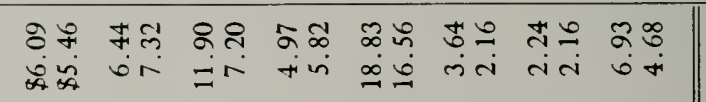

고요

i

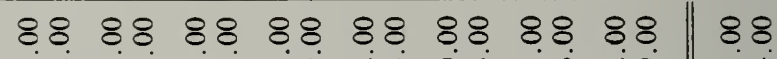

आ

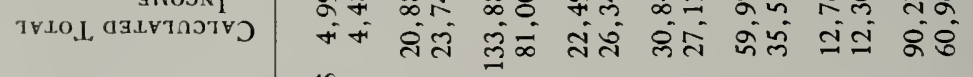

उேㅎํ $\infty$

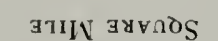

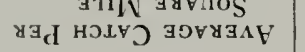

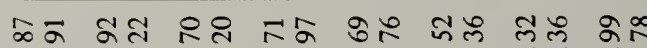

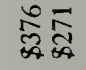

00 -

ํㅛ

皮

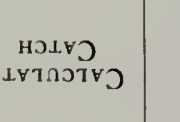

豆劣

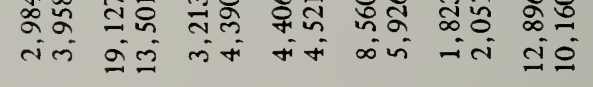

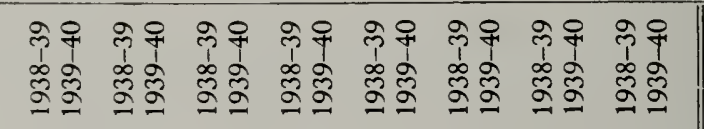


the catch showed reduced populations in the River Bluffs and Bottoms, the Black Prairie and Gray Prairie regions. All other regions showed an increased catch. Drought during the fall of 1939 may be advanced as a reason for the decline in the Black Prairie and Gray Prairie regions. The cause or causes for the appreciable decline in the River Bluffs and Bottoms Region are not known, but they may be suggested by certain social and economic factors peculiar to the region. It is certain that this area bears a heavy trapping and fur hunting pressure. Reasons for increased catches in the northern and northwestern parts of the state are likewise unknown.

Habitats.-Illinois mink habitats are so variable that they range from glacial marshes in the northeastern part of the state to cypress swamps in the southern tip, figs. 21 and 22. It is doubtful which type of habitat offers the better range; the yield for Lake County averaged 2.73 minks per square mile for the two seasons of the survey, and Union County, just north of the cypress swamps, averaged 1.79 during the same period. The cypress swamps themselves would probably have shown a greater density in catch.

The Lake County habitat is characterized by marshes, shallow lakes of glacial origin, little timberland and large muskrat populations; Union County, by much heavy timber, numerous small creeks and springs, steep bluffs and a low muskrat population. The cypress swamps are even more heavily forested, but without bluffs and muskrats, and with but few springs. Comparable populations in such widely diverse habitats, in addition to general distribution in every county in Illinois, indicate great adaptability in minks and suggest that the species may long remain one of the more important fur animals of the state.

Ability to make use of almost any sort of cover in the vicinity of water gives the mink a great advantage over larger and more intolerant animals, such as the raccoon, figs. 23 and 24. The shore lines of streams, fig. 23, lakes, ponds and marshes; small runs and ravines, fig. $2+$; drifts, windfalls, brush, timberland and slashings: all afford mink cover. In the Glacial Lakes Region, marshy shore lines, stream banks and muskrat houses provide cover and denning areas. In the Gray Prairie Region, cattail-bordered mine ponds and small lakes, bogs and springs make up for the intermittent nature of the many small streams. In the vicinity of many of the ponds and springs there are thick slashings, the result of hasty logging of mine props, where a combination of brush, stump sprouts and second growth offers excellent mink cover. The Northwest Hills provide good forest cover and the Northwestern Sand Prairie contains considerable marsh area. Both regions have numerous small, permanent waterways; drainage ditches partly replace streams in the latter region. In the Black Prairie and Central Sand Prairie regions, lack of water is the greatest shortcoming; most of the streams and ditches, especially in dry years, are intermittent. During the fall of 1939 the water shortage in these two regions was serious, and probably accounts in part for the reduced mink yield.

Along the Illinois River, many minks live on or near wooded islands, isolated by marsh and shallow water. They den chiefly in hollow tree bases, especially willows, or in the ground, and in some cases muskrat trappers here are not aware of their presence, often in comparatively large numbers.

Trapping and Hunting.-Approximately 87 per cent of the Illinois mink catch was taken in traps during the two seasons of the survey. Many minks, especially along the Illinois and Mississippi rivers and in the Glacial Lakes Region, were taken in connection with muskrat trapping. Nearly all such minks were caught without the use of bait, trappers taking advantage of the mink's habit of traveling muskrat runs and entering muskrat houses and dens. Most bait sets were in shallow water and therefore operative only during nonfreezing weather. Other sets were made on logs, in narrow ditches and runs, and at points along waterways where minks were likely to step. Nearly all of the catch in the Glacial Lakes, Northwest Hills, Black Prairie and the Northwestern Sand Prairie regions was made by trappers.

About 13 per cent of the Illinois mink watch for the two seasons of the survey was by hunters. In the Central Sand Prairie in 1939-40, hunters accounted for 58 per cent of the catch. In no other 


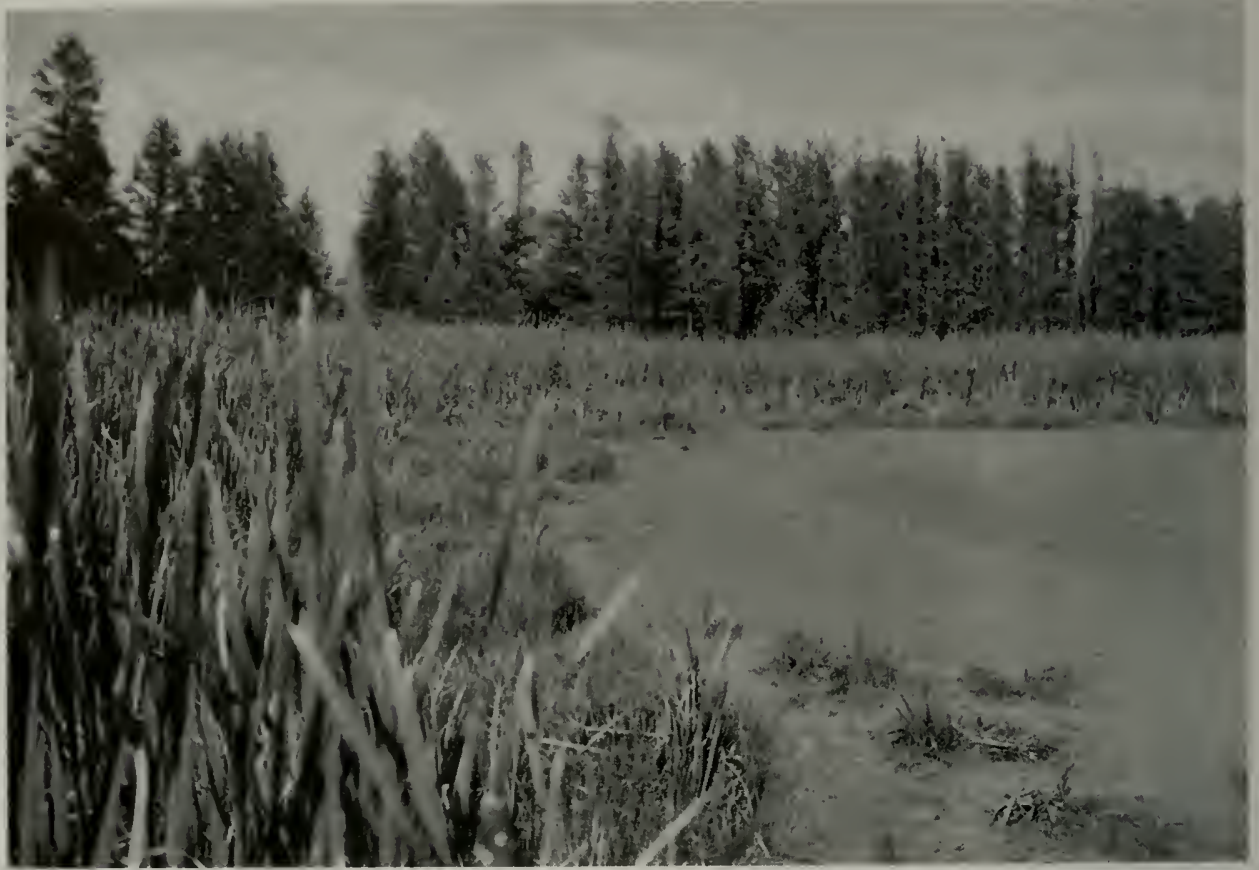

Fig. 21. - Minks are adaptable to habitats ranging from tamarack bogs in extreme northern Illinois to ...

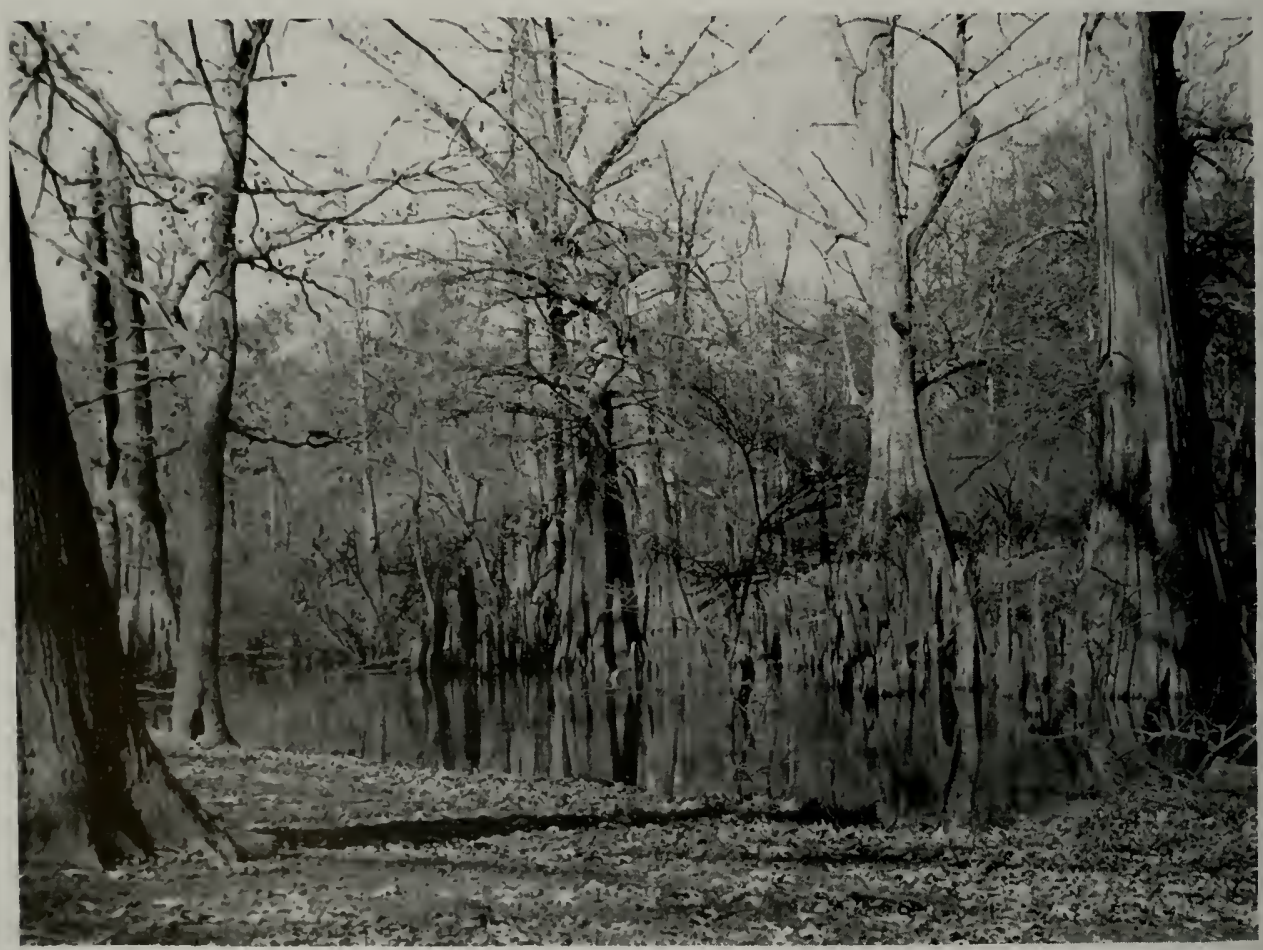

Fig. 22.- . . swamps of cypress and tupelo gum in the southern tip of the state. 


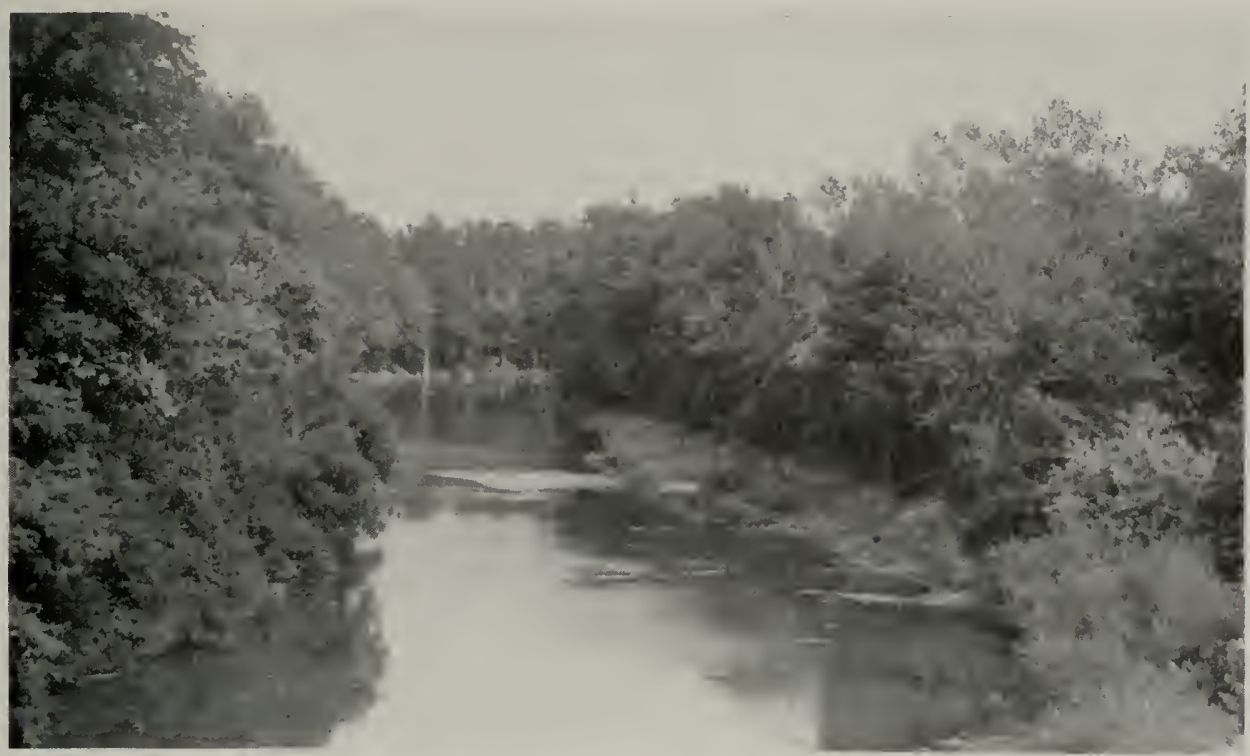

Fig. 23.-Saline River, Gallatin County. This forest-bordered stream illustrates one type of mink habitat common in the southern and southeastern parts of Illinois.

region did the hunter catch exceed 35 per cent. Both day and night hunting was practiced, the former being the favored method during tracking snows. Once the den was located, it was comparatively simple to dig the animal out, a practice now specifically prohibited by law. IVhen sighted, such minks were usually shot with a small rifle or pistol, or were chased out to be caught by dogs. Occasionally, a good

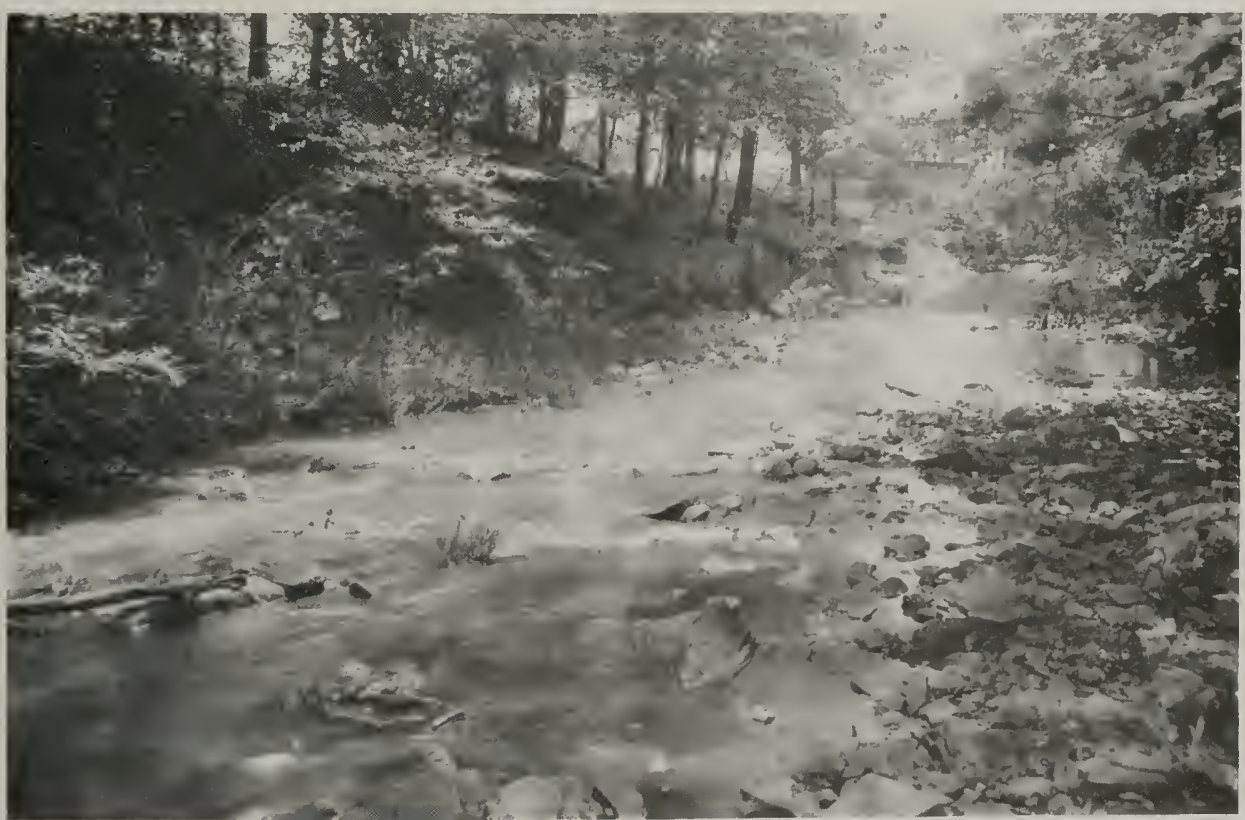

Fig. 24.-Gibbon's Creek, Pope County. Rock-bottomed creeks such as this offer suitable mink range in southern Illinois. 
dog would actually tree a mink and hold it long enough to be shot. More common1y, however, minks were "treed" in holes, windfalls, hollow snags or logs, or in piles of debris, and were taken by unstinted use of ax or spade. For the state as a whole, during the two survey seasons, about onehalf of the trappers and one-fourth of the hunters were successful in taking minks, table 11.

Management.-A trapping season Nov. 15 to Jan. 15, or Dec. 1 to Jan. 31, is considered satisfactory for this species. Destruction of mink dens should be stopped, although the loss of ground dens is obviously less detrimental to minks than the cutting of den trees is to raccoons. A general program of habitat restoration featured by reforestation, erosion control, watershed protection and protection against fire and overgrazing would greatly benefit mink as well as other wildlife populations. Close pasturing of stream and ditch banks is very destructive to both mink and muskrat range. Drifts, debris, windfalls and brushy growths, where land use permits, provide very acceptable mink cover. Wide-scale mink control over large regions, in the interests of poultry or game, is inadrisable.

\section{Long-Tailed Weasel}

Two kinds of weasels are listed by Necker \& Hatfield (19+1) as occurring in Illinois. These are forms of the longtailed and least weasel. The latter, of little or no importance in the fur trade, occurs in only a few of the northeastern counties, with one record from Lee County.

Unlike species of more general distribution over the state, such as the skunk and mink, the long-tailed weasel is concentrated principally in the more northern counties. It occurs, however, in every region, and in all is one of the less important fur animals. In 1938-39, the total calculated catch was 8,889 , worth $\$ 3,111.15$; in $1939-40$, it was 8,796 , worth $\$ 3,078.60$, table 12. The decline in the second season was only about 6 per cent; all other species except the gray fox, which gained slightly in the second season, showed a greater catch decline than the weasel.

No long-tailed weasels appeared in the catch data from the $W$ estern Prairie in
1938-39, and the same was true of the Gray Prairie in 1939-40. While we are certain that the catch in these regions was very low, we are equally certain that a few of these animals were taken in the areas during the years for which there are blanks, table 12 . 'These blanks suggest inaccuracies in the data, which a larger sample might have eliminated. In the IVestern Prairie Region, the calculated catch for the season in which the weasel was represented was only $0.0+$ per square mile, and in the Gray Prairie Region only 0.03 per square mile. The error therefore is small. 'The average pelt value of 35 cents, table 5 , is only about one-third the price received for weasel skins at times during the previous decade.

Popularity.-The long-tailed weasel is usually considered one of the most undesired fur animals in Illinois. Trappers show little enthusiasm for weasels because their fur is of little worth and they may spoil sets made for foxes, minks and other more valuable species. Farmers and sportsmen consider them the worst mammalian enemies of poultry and game. Of a total of $12 t$ answers concerning weasel popularity, 25 favored fewer weasels. Coming directly from fur-takers, these answers represent a positive indictment. Several years ago, when trappers commonly averaged $\$ 1$ for long-tailed weasel pelts, they were an appreciated item. As determined in the survey, unpopularity was general, but most pronounced in the southern part of the state.

Damage and Control.-There is litthe question concerning the destructiveness of individual weasels. As a species, the long-tailed weasel may be considered bloodthirsty, and its reputation for ruthlessness in killing is well founded. It should be remembered, however, that this trait is exercised as readily and as vigorously on meadow mice as on chickens or ducks. Weasels kill thousands of rats and mice, and in some situations are good friends of the farmer. We recommend that destructive weasels be killed as promptly as possible and, in view of the low pelt value, without regard to season. Trapping is probably the most effective control, and traps set around a fresh kill are almost certain to make a catch.

Populations.-Nowhere in Illinois can the long-tailed weasel population be 
considered dense. The heaviest catch for the two seasons of the survey was in the Glacial Lakes Region, where the yield averaged 0.82 weasel per square mile per year, table 12 . The next heaviest catch was in the Northwestern Sand Prairie Region, with takes of 0.41 and 0.89 pelt be situated in the vicinity of farm outbuildings. Haystacks, brush piles and windfalls are also preferred units of the habitat, the animals probably heing attracted to such places because of the abundance of mice. In the River Bluffs and Bottoms Region, weasels frequent the

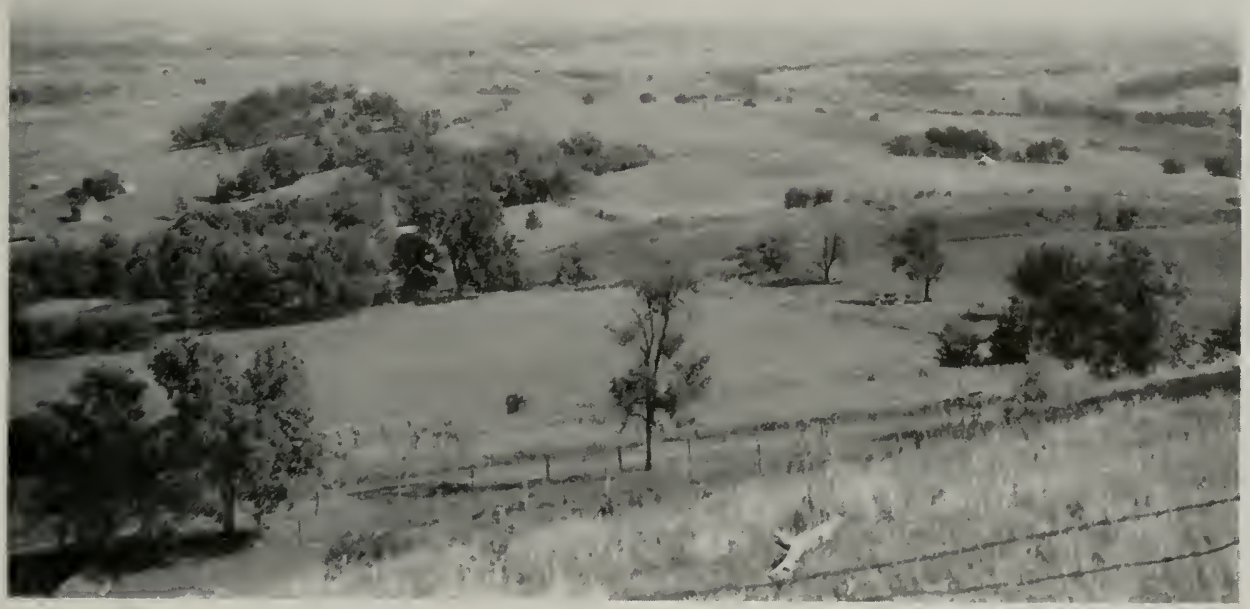

Fig. 25.-Rolling terrain and comparatively limited agricultural use of the land characterize the Northwest Hills Region. This and other northern Illinois regions produce most of the long-tailed weasels taken in the state.

per square mile in the two years. The Black Prairie yield was 0.23 and 0.15 pelt per square mile, mainly from the northern half of this region. In all other regions the catch was very low.

The writers have no explanation for the apparent regional fluctuation in the catch. Few trappers expressed an opinion on the changes in long-tailed weasel population. Of those who did for the season of 193839 as compared with the previous season, 28 reported an increase, 28 no change and 8 a decrease, table 12 . With a continued poor demand for weasel furs and with normal populations of rodents and rabbits, it is reasonable to expect some increase in weasel numbers.

Habitats.-The long-tailed weasel is an upland furbearer. Rolling farms, pastures and brushland apparently provide the best Illinois hahitats, figs. 5 and 25. Fencerows of shrubs or stone provide typical farmland den sites; dens may often steeper hillsides as well as the farmed and pastured areas. In all regions, dense cover adjacent to fields or grassland provides favored range.

Trapping.-Long-tailed weasel trapping is very simple and in Illinois is probably not deliberately practiced outside of the northern counties. A large part of the catch is incidental, especially in connection with skunk trapping. Weasels are readily attracted by fresh, bloody meat bait. Traps of small size, such as No. 1, are usually placed along fencerows, stone fences and piles, wood lots, brushy areas, ditches and creek banks. Very little, if any, of the catch is taken by hunting.

In the two-season survey, white weasels amounted to approximately 28 per cent of the calculated catch; a small percentage of the pelts were mixed, and by far the largest percentage were brown. Lake County, with 36 per cent, showed the largest percentage of white pelts. The 


\begin{tabular}{|c|c|c|c|c|c|c|c|c|c|c|}
\hline \multirow{2}{*}{ 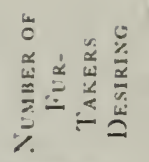 } & 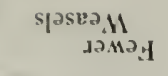 & $-n$ & $0-$ & $n-$ & + & o- & 44 & 00 & -0 & $=\infty$ \\
\hline & $\begin{array}{l}\text { a7oln } \\
\text { spasta.1I }\end{array}$ & $\pi$ & On & oun & $+\bar{\lambda}$ & कत & $\mathrm{Or}$ & -0 & 90 & $\approx 3$ \\
\hline \multirow{3}{*}{ 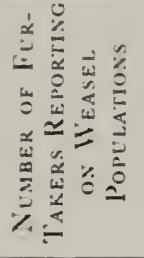 } & 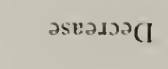 & -0 & 00 & $o-$ & 00 & Or & 00 & $0-$ & no & $\infty+$ \\
\hline & วรินยบว $\mathrm{N}$ & -+ & on & $\infty-$ & o in & or & -0 & -- & -0 & 兄公 \\
\hline & วระว.ภน & or & 00 & -- & $\pm \Omega$ & $\infty a$ & $n d$ & 00 & 00 & జ्र \\
\hline \multirow{2}{*}{ 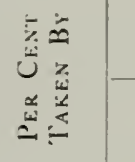 } & sдąun $_{H}$ & 00 & 0 & 00 & 00 & 00 & 00 & 00 & 01 & 00 \\
\hline & saddes.L. & $\S \cong$ & $1 \S$ & $8 \&$ & 88 & 88 & 88 & 88 & 81 & 88 \\
\hline \multicolumn{2}{|c|}{ 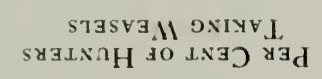 } & 00 & 10 & 00 & 00 & 00 & 00 & 00 & 0 & 00 \\
\hline \multicolumn{2}{|c|}{ 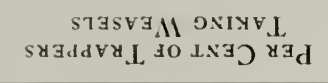 } & $\infty \simeq$ & 16 & $a n$ & $\vec{\sim}+\infty$ & हेल & $\cong 2$ & tru & $\infty$ & $\cong \pm$ \\
\hline \multicolumn{2}{|c|}{ 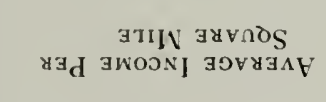 } & $\begin{array}{l}1 \\
0 \\
0 \\
0\end{array}$ & $1 \stackrel{0}{0}$ & t: & $\frac{ \pm}{0}$ & ते ते & $\begin{array}{ll}\infty & 2 \\
0 & 0 \\
0 & 0\end{array}$ & $\begin{array}{l}0: 0 \\
0 \\
0\end{array}$ & $\ddot{0}$ & 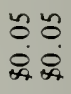 \\
\hline \multicolumn{2}{|c|}{ 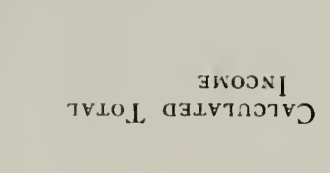 } & $\begin{array}{l}\simeq \infty \\
=\infty \\
=\infty\end{array}$ & $\begin{array}{l}\text { in } \\
\text { in }\end{array}$ & 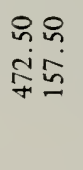 & 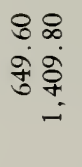 & 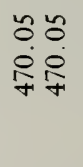 & 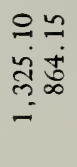 & $\begin{array}{l}\text { \&\& } \\
\text { भi̊ }\end{array}$ & $\begin{array}{l}2 \\
\infty \\
0 \\
2 \\
2\end{array}$ & 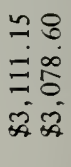 \\
\hline \multicolumn{2}{|c|}{ 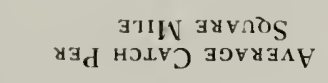 } & $\stackrel{\infty}{0}$ & 10 & $\begin{array}{l}14 \\
\because 0\end{array}$ & $\begin{array}{l}\mp \infty \\
00\end{array}$ & $\begin{array}{l}1 \\
\infty \\
0 \\
0\end{array}$ & तु? & $\begin{array}{l}10 \\
00 \\
0\end{array}$ & $\frac{1}{0}$ & $\begin{array}{l}0: 2 \\
00\end{array}$ \\
\hline \multicolumn{2}{|c|}{$\begin{array}{c}\text { Hวนทว } \\
\text { TVLOL बรLVTกวาทว }\end{array}$} & 字京 & $\stackrel{?}{2}$ & $\begin{array}{l}\text { 요욤 } \\
\text { ? } \\
\text { ?- }\end{array}$ & $\begin{array}{l}\infty \\
\infty \\
\infty \\
\infty \\
-i \\
-i\end{array}$ & कृ & $\begin{array}{l}\infty 0 \\
\infty \\
\infty \\
\text { mi }\end{array}$ & 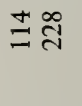 & $\overrightarrow{\mathrm{m}}_{1}$ & $\begin{array}{l}20 \\
\infty \\
\infty \\
\infty \\
\infty\end{array}$ \\
\hline \multirow{2}{*}{\multicolumn{2}{|c|}{ 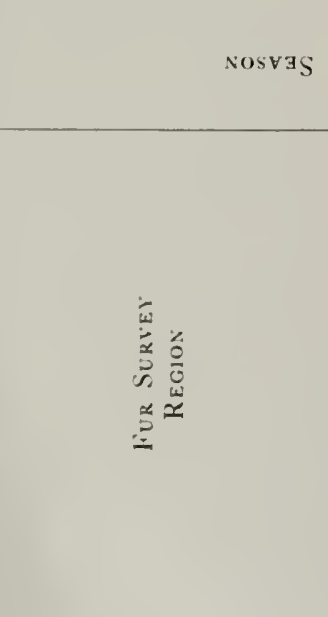 }} & 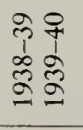 & 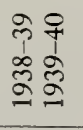 & 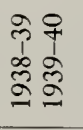 & 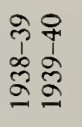 & 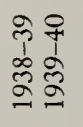 & 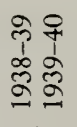 & 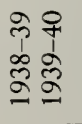 & 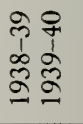 & 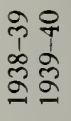 \\
\hline & & 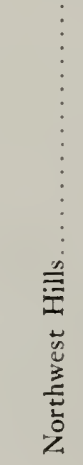 & 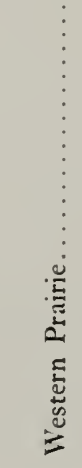 & 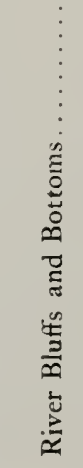 & 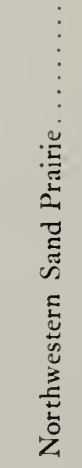 & 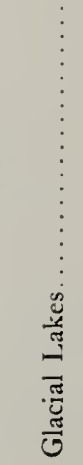 & 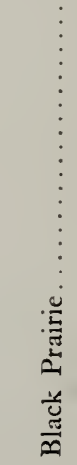 & 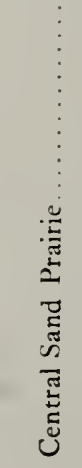 & 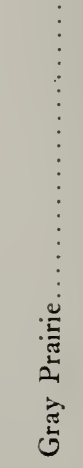 & $\begin{array}{c}\vdots \\
\vdots \\
\frac{n}{0} \\
. \Xi \\
\vdots\end{array}$ \\
\hline
\end{tabular}


proportion decreased progressively southward, white weasels being rare in central Illinois.

Management.-A season opening Dec. 1 and closing Jan. 31 is satisfactory for maintaining the present long-tailed weasel population.

\section{Red Fox}

According to Bailey (1936), two varieties of the red fox occur in Illinois. These are the northern plains red fox, $V$ ulpes fulva regalis Merriam, and the eastern red fox, Vulpes fulia fuli'a (Desmarest). The range of the two subspecies overlaps, particularly in the northern part of the state. Necker \& Hatfield (19+1) list only $V$ ulpes fulra Desmarest.

The red fox occurs throughout the state. In the seasons of the survey it ranked seventh in number of pelts and sixth in value, table 20 . In 1938-39, the calculated catch was $10,67+$ pelts, worth $\$ 32,022$; in $1939-40$ it was 6,688 pelts, worth $\$ 18,392$, table 13 . 'These numbers represent only 0.76 per cent of the total fur catch over the 2-year period, table 20 . During the first year, red fox pelts averaged about $\$ 3.00$ each, and during the second, about $\$ 2.75$ each, table 5 , or about one-fourth of the $192+-29$ value.

Popularity.-In Illinois, the red fox is one of the most controversial fur animals. Here, as elsewhere, it commands a great deal of public interest. In many southern Illinois localities, it is regarded highly as a sporting animal, and in many northern parts of the state it is vigorously condemned as a pest. Because of its miceand rabbit-destroying tendencies, it is looked upon with favor by orchardists in the southern zone, where it has had the legal status of most other fur animals. In the northern zone, it was unprotected in both years of the survey and might be hunted and killed at any time. Several counties in the northern zone recently offered bounties of $\$ 2$ for adults and $\$ 1$ for pups. In the central zone, the red fox was protected in 1939-40 but not in 1938-39. Due to increasing numbers, red foxes are in many parts of the state growing in popularity with day hunters who may "walk them up" or hunt them with dogs.

Farmers and upland game hunters dis- like the red fox because of its actual and alleged depredations on poultry, quails and pheasants. On the other hand, in certain southern localities, the activities of fox-hunting clubs over a period of many years have instilled in the public mind a respect for the species. In such localities, persons of differing opinion act and express themselves privately; and trappers in such communities do not readily report their fox catches.

Of the answers received from fur-takers contacted in the two seasons of the survey, a total of 239 favored more and 78 favored fewer red foxes. Non-fur-takers are known to be emphatic in their opposition to more red foxes. In comparison with the attitude toward the mink and muskrat, this degree of unpopularity may be considered an indictment against the species. Most fur-takers and all trappers valued the red fox in terms of income and desired to see it protected during months of the year in which its fur is of no value. It is apparent that the species suffers through lack of accurate, widespread knowledge concerning its food habits. Under present conditions it happens too often that the harm foxes do lives on, while their beneficial traits go unnoticed and unknown.

Damage and Control.-Complaints concerning the loss to foxes of small pigs, as well as poultry and game birds, are frequently heard. During the survey, many complaints involving fox depredations on chickens were received. It was, however, difficult to obtain specific cases of extensive damage. Some farmers and many sportsmen advised that they killed foxes at every opportunity; other farmers thought highly of fox-hunting clubs in the belief that they kept the foxes off their property.

In appraising actual damage, it seems safe to state that foxes take poultry, and to a lesser degree pigs, rather generally over the state, but only in a very few cases are the animals a serious menace to poultry or stock raising. 'The predation of foxes on game birds has been studied only locally, and is subject to so many variables that no statewide evaluation of this controversial issue can be made. In one Michigan locality, Dearborn (1932) found that mammals, chiefly rabbits and mice, made up over to per cent of the summer food of red foxes in 1930 and 


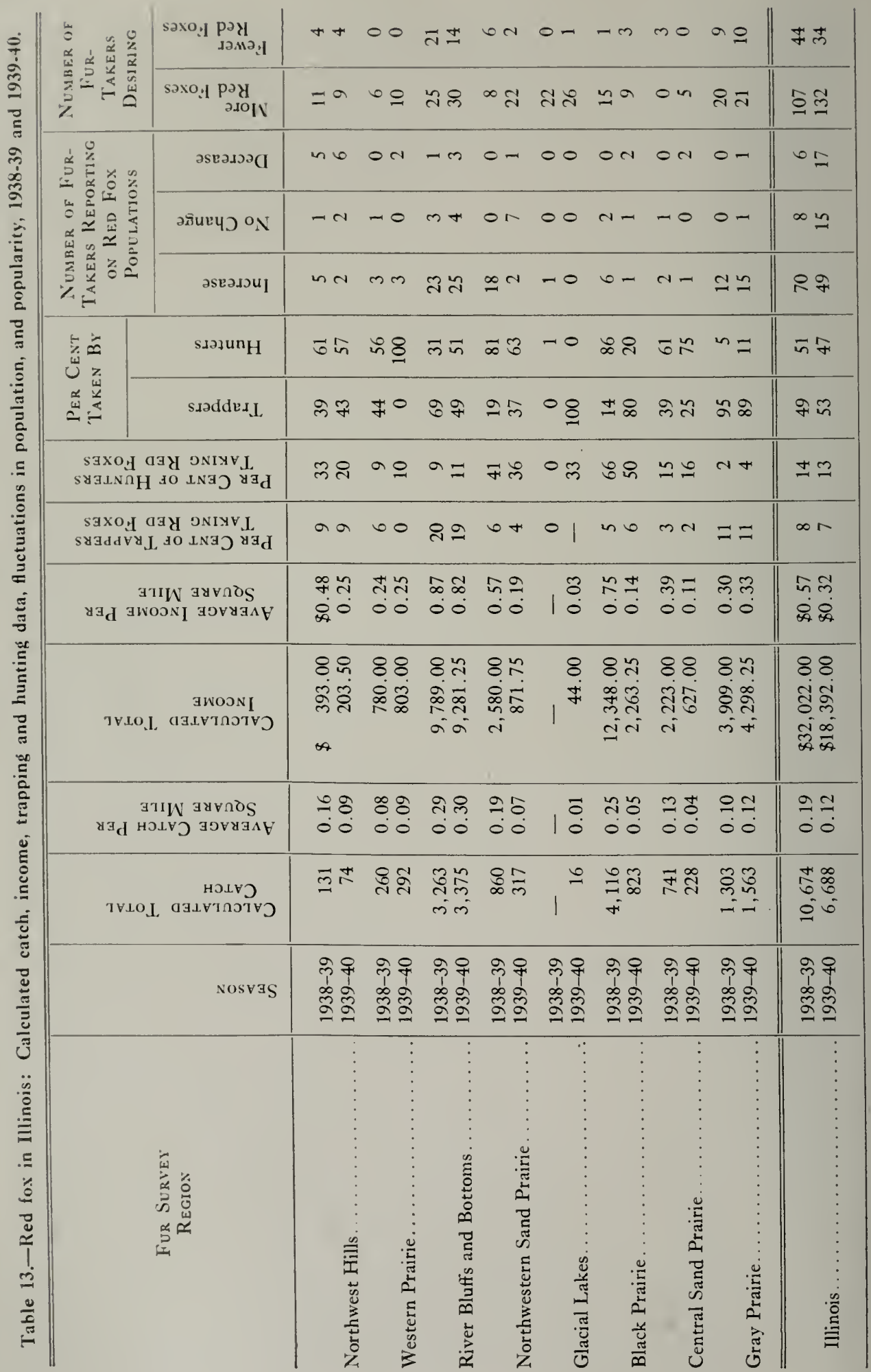


over 90 per cent in 1931. Other workers have reported similar findings. Predation on game is probably rather general, but, except perhaps locally, it is doubtful if foxes ever threaten game populations with extermination. Foxes are most destructive during the spring months when foraging for their young; at all seasons availability of prey largely determines the kind of food and the degree to which it may be taken (Errington 1937a). One of the best ways of protecting poultry, therefore, is to keep it out of the fields and woods.

Trapping and hunting are recommended as the best means of controlling red foxes; a well-trained dog will keep all foxes at a distance. The use of poison and gas, now illegal against fur animals in Illinois, is not recommended at any time. The payment of bounties and the killing of animals when the pelts are valueless invariably result in waste of money and valuable furs. It should not be forgotten that one or more prime fox pelts per year may cover, or more than cover, predation losses on the average farm. In the necessity of reducing fox populations over sizable areas, more intensive hunting and trapping are suggested during the winter months when the fur is prime. During the trapping season local trappers of ten gladly aid in control.

Populations. - In the opinion of numerous experienced trappers, an increase in the red fox population became apparent about 1931, and a peak was reached in 1934-35. Since that time the population seems to have remained relatively stable except for minor or local fluctuations. The high 1938-39 catch probably does not represent a peak year in either value or number of pelts, for the following reasons: low fur price, better employment than during the depression years and the generally prosperous condition of agriculture, especially in the corn belt. In 1939-40, the decreased catch of about 37 per cent below that of the preceding year may indicate a cyclic reduction in numbers. Of a total of 165 expressions of opinion from fur-takers, 119 indicated a recent increase in red fox numbers, 23 no change and 23 a decrease.

Every region was represented in the catch during the survey, but the Glacial Lakes catch was extremely low, only 0.01 red fox per square mile in 1939-40. Red foxes were not represented in the data for this region the preceding year. The heaviest catch, 0.29 and 0.30 pelt per square mile, was taken in the River Bluffs and Bottoms Region. Thus, in no region did the catch average as much as one red fox per 3 square miles. The red fox and the weasel have lower averages for the state as a whole than any other fur animals except the gray fox and other species that do not have state-ride distribution.

Habitats.-Catch figures indicate that the best red fox habitat in Illinois is offered by the River Bluffs and Bottoms Region, and the second best by the Black Prairie. The cover of the first region, with its timber, brushland, bluffs and steep narrow ravines, irregularly interspersed with fields and pastures, should be expected to provide good habitat, fig. 26. Cover on the Black Prairie is furnished chiefly by timbered bottomland, woodlots and waste areas such as stripmines and abandoned gravel pits. Stripmines in Fulton and Vermilion counties are known to hold comparatively large numbers of red foxes. Hunters, on snow, often jump foxes in daytime in open fields. The intermittent nature of streams in the Gray Prairie, Central Sand Prairie and many parts of the Black Prairie lowers the general quality of the habitat in these regions. As reflected in the catch, the Glacial Lakes offers the poorest red fox range, but this indication is hard to reconcile with the known cover, water and food resources of the region. So far as the writers are aware, red foxes here are not accorded special protection by fox clubs or other organizations. It seems probable that the method of trapping, wherein a great majority of the sets are made for muskrats and minks, precludes the taking of many foxes. Because of low price, little deliberate fox trapping was done anywhere in the state during the survey years.

Trapping and Hunting.-Approximately one-half of the Illinois red fox catch was made by trappers and one-half by hunters, as determined in the survey, table 13. The degree of both trapping and hunting, however, varied widely by regions. 'Trapping predominated in the Gray Prairie and Glacial Lakes regions; hunting was the more common method of capture in the Northwestern Sand Prairie, the Central Sand Prairie and the 


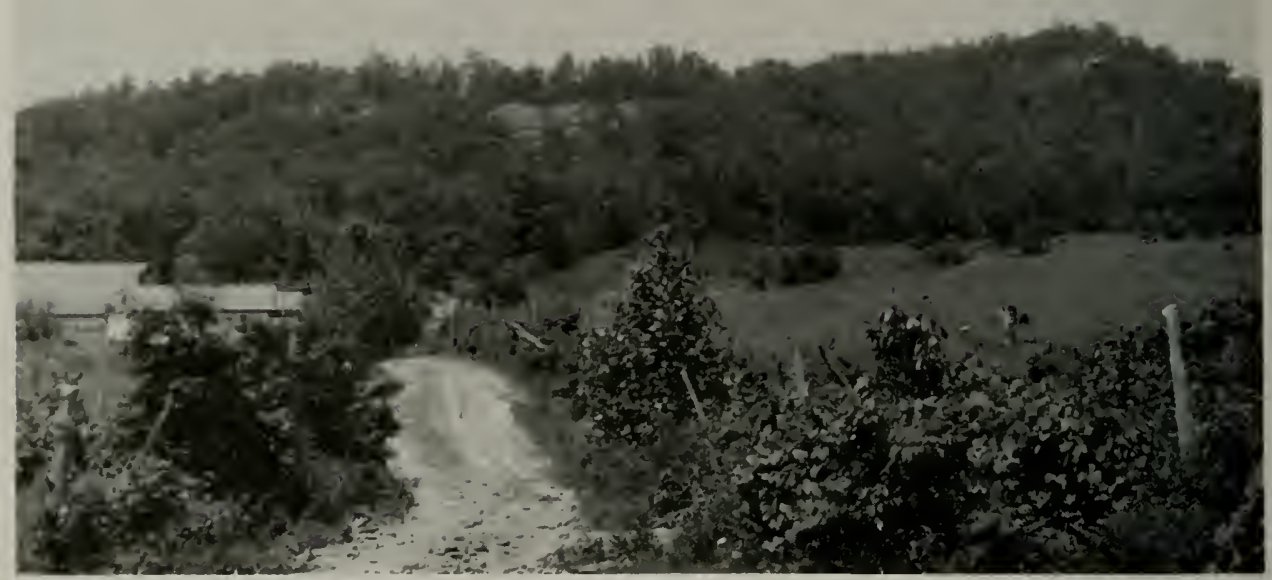

Fig. 26.-Good red fox range in the Ozark foothills, Hardin County, Shawnee National Forest. This is in the River Bluffs and Bottoms Region.

Northwest Hills regions. In other regions both methods were employed about equally, but with wide variations by years. For example, in the Black Prairie, trappers took only 14 per cent of the red foxes in 1938-39, but 80 per cent the next year. A somewhat similar situation was noted in the River Bluffs and Bottoms Region.

$N_{0}$ attempt will be made here to give an account of fox hunting in Illinois. Its derotees are fully as enthusiastic as those who pursue the coon, and the chase itself is probably even more of a social event. Fox hunters are typically "crony" groups, often rivals in other walks of life but able to find common ground in baying dogs, camp fires, stimulants and stories. Fox hunting is one of the great American traditions, and a diversion in which the recreational returns far outweigh any monetary value of the furs. Farmers and business inen, rural and urban divellers, make up the membership of practically all foxhunting clubs. Fox hunts or fox drives, staged in daytime, are becoming very common in the Black Prairie Region.

Fox trapping is probably the best example of the trapper's art. Few species are credited with more intelligence than foxes in avoiding traps, and years of experience seem to be necessary before a trapper acquires the status of a fox expert. Successful trappers use both baited and nonbaited sets. Traps placed in trails, gaps in woven wire fences, on mounds overlooking some natural food or lure are often successful. When bait is employed, it is commonly buried around a stump or rock and traps placed in the freshly excavated soil. Many successful sets are made on or around old straw stacks.

Fox hunters often strenuously oppose the use of traps for foxes, as well as other animals, because of the possibility of catching dogs.

Management.-A few foxes "go a long way." In farm communities there is more danger of red foxes becoming too numerous than of probably any other fur species. Since the population trend in Illinois during recent years has been upward, there is no need of protection beyond that normally accorded to other fur animals in this state. Indeed, it may become desirable to reduce local red fox populations, and increased hunting and trapping in season is the method recommended. IVe feel that bounties are not effective in control and that they may encourage bootlegging of fox furs and other undesirable practices. The destruction of adult foxes and pups during the summer months results in waste and should be discouraged except in cases where animals of known guilt are involved.

For most years, an open season coincid- 
ing with that for all other fur animals, with control based on more intensive hunting and trapping in season, offers the simplest plan of management, and one fair to hunters and trappers alike. An unprotected status of the species in the northern and central zones may be justified in periods of a decidedly upward trend in red fox populations. The period for dog training should coincide with that recommended for coon dogs, Sept. 15 through Jan. 31, and for the same reason.

\section{Gray Fox}

The gray fox is essentially a timberland species, and in Illinois in the two seasons of the survey was found in greatest density in the River Bluffs and Bottoms Region, fig. 27. Here the calculated catch averaged 0.35 pelt per square mile in 1938-39 and 0.42 per square mile in 1939-40, table 14. The Northwest Hills ranked second in catch density, with an average of 0.29 and 0.20 pelt per square mile in 1938-39 and 1939-40, respectively. The Northwestern Sand Prairje and the Glacial Lakes, with trace yields averaging 0.03 and 0.01 pelt per square mile, respective- ly, were represented only in 1938-39. The survey indicated that the species appeared in the catch only in these four regions. In 1938-39, the calculated catch of gray foxes was,+ 328 , worth $\$ 7,574.00$; in 1939-40, 4,889, worth $\$ 8,555.75$, table 14. Gray foxes ranked eighth in the catch for these two seasons, table 20. The average price for these years of $\$ 1.75$ per pelt, table 5, may be considered lower than normal.

Popularity.-The gray fox is generally unpopular. It lacks the sporting qualities of the red fox, and in the public mind $i t$ is a serious predator on poultry and game. Fur-takers are indifferent because of the low pelt value. Of the total of $1+2$ opinions expressed by trappers and hunters, 92 favored more and 50 fewer animals. Thus, the gray fox, along with the opossum and coyote, ranks very low in the estimation of Illinois fur-takers.

Damage and Control.- The remarks made under this heading for the red fox are generally applicable to the gray fox. Some persons regard the gray fox more destructive to game, particularly forest game, than the red fox.

Populations.-The data at hand indi-

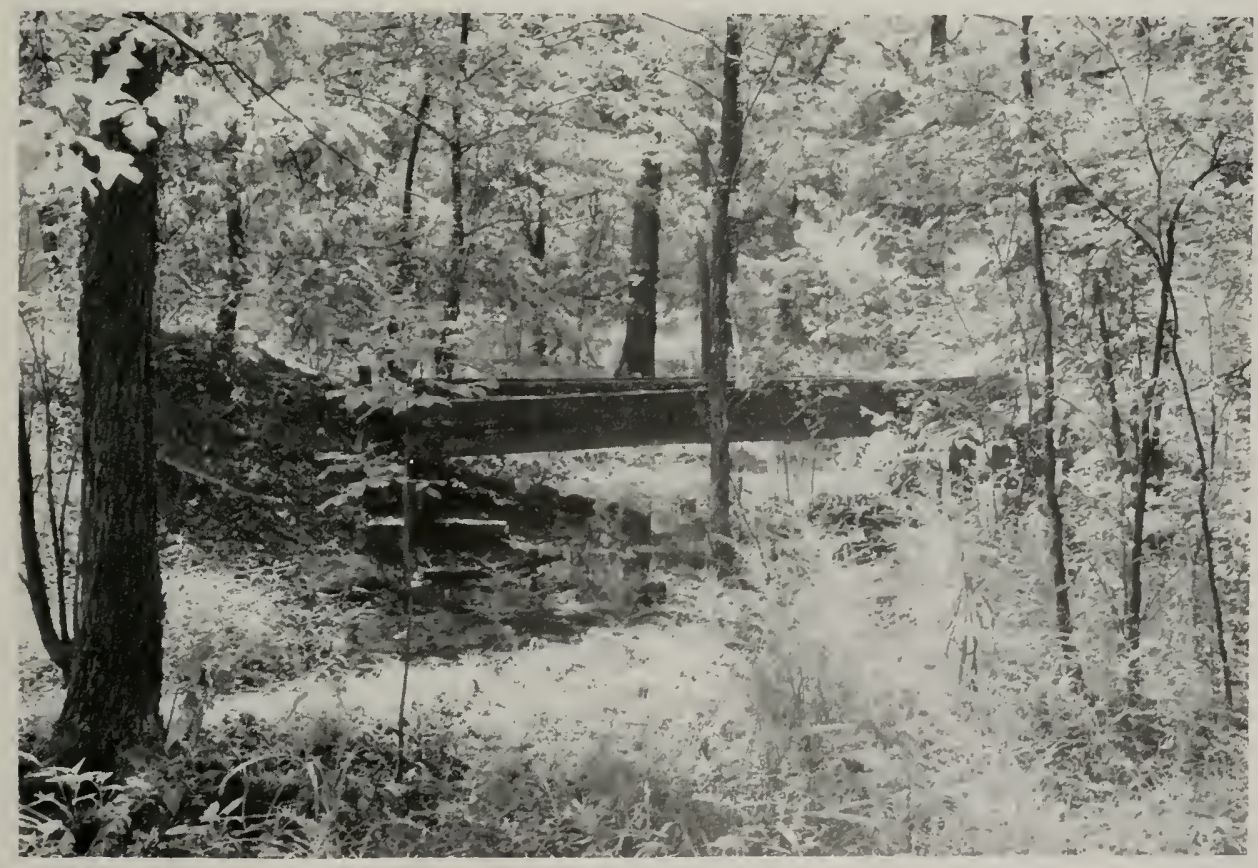

Fig. 27.-The gray fox is typically a forest-inhabiting species. The foothill and river bluff types of Union County offer excellent range for this fox. 


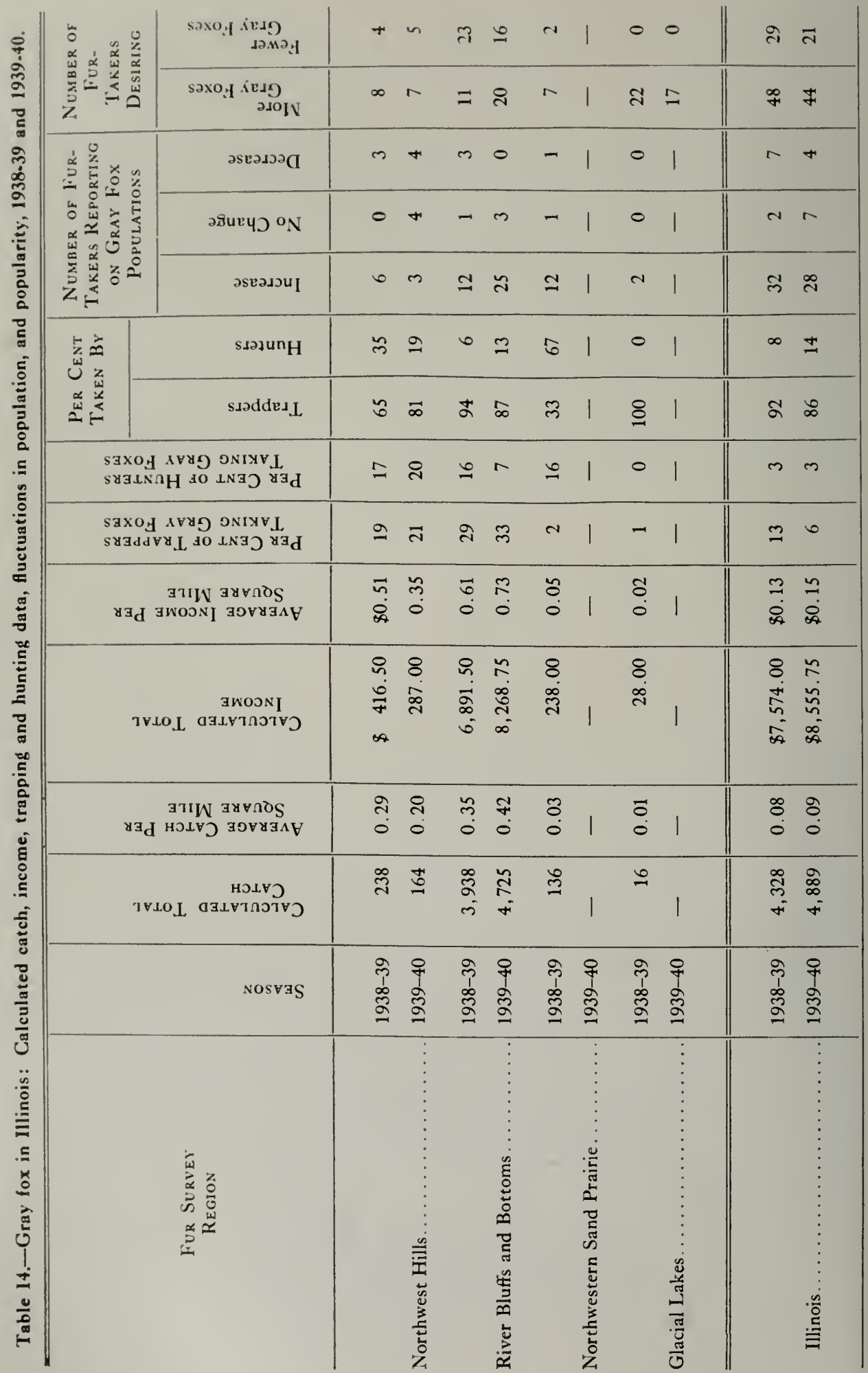


cate a slight increase in the gray fox population in 1939-40 over that of the preceding year; thus, this species was the only one to show an increase during the period covered by the study. In the River Bluffs and Bottoms, gray foxes appear to be more numerous than red foxes and in favored localities may show a ratio of two to one over the reds. In the regions from which catches were recorded, the gray fox showed an average catch for the survey period of about 0.26 pelt per square mile as compared with slightly less than 0.16 for the red fox, but for the state as a whole the red fox catch was approximately twice as heavy, being almost 0.16 per square mile compared with about 0.08 per square mile for the gray fox, tables 13 and 14.

In the Northwest Hills and River Bluffs and Bottoms regions, the only two in which the gray fox was plentiful, there was comparatively little variation in the population as indicated solely by catch in the two survey seasons. Red fox catches in four regions indicated great differences in numbers between the two seasons, table 13. It may be that the gray fox is less cyclic, but on the basis of data at hand such a statement represents little more than speculation. Higher fur prices would undoubtedly have resulted in larger catches, and for this reason it is impossible to estimate population on catch alone. It is certain that the gray fox occurs over a larger area and in greater numbers than indicated by survey data.

Habitats.-The gray fox range in Illinois is not decreasing as rapidly as former$1 y$, because of the fact that many brush areas, refuges and forest preserves now occupy lands once farmed or subject to lumbering operations. The best gray fox habitat in Illinois is in the River Bluffs and Bottoms Region, which is characterized by heavy timber stands, underbrush, rock outcrops and deep, shady ravines, fig. 26. The Northwest Hills and the Northwestern Sand Prairie offer similar habitats. The Glacial Lakes Region is more parklike and lacks rock outcrops. Why no gray foxes were reported in the catch from the comparatively well-wooded Gray Prairie Region is not known. Distribution of the gray fox, as indicated by the survey, is principally over the northern half of the state, except for the River
Bluffs and Bottoms Region. This fox, to a greater degree than the red fox, is intolerant of man and cultivation.

Food for the gray fox in all its habitats is probably ample, consisting of rabbits, mice, birds, insects and fruits. The persimmon is said to be important in regions where it occurs.

Trapping and Hunting.-Over three-fourths of the Illinois gray foxes were taken by trappers and less than onefourth by hunters in the years of the survey. There is little deliberate attempt in this state to take them in traps; most are incidentally captured in sets made for red foxes, skunks and other land species. Trappers specifically trying for them employ methods similar to those used for the red fox.

Gray fox hunting offers little of the excitement characteristic of red fox hunting. Chases seldom last more than $30 \mathrm{~min}$ utes and often not long enough to allow the hunter to make a stand. Gray foxes are sometimes treed in bushy or inclined trees, from which they are easily shot.

Management. - Suggestions given under this heading for the red fox are generally suitable for the gray fox.

\section{Badger}

Badgers occurred in low numbers over the Northwest Hills and the Northwestern Sand Prairie Regions in 1938-39 and 1939-40. Probably at no point in the state could they be considered common. Although the Illinois game codes of 1937 and 1939 appear to have provided full protection for badgers, a common interpretation of the statutes was such that these animals were hunted and trapped through at least the season of 1938-39. The survey indicated that 116 were taken in 1938-39, but only 8 in 1939-40. Although these data are not considered reliable, the reduction in 1939-40 suggests that the correct interpretation of the law, and an appreciable measure of protection, began about this time. The game code put into effect in $19+1$ clarified the provision that accorded to badgers a yeararound closed season.

'The low price of badger fur, averaging only about 75 cents per pelt for several years prior to $19+1$, restricted the catch, and probably was important in prevent- 
ing complete extirpation of the species from the state.

Badgers are generally considered a nuisance, and little appreciation accrues among horses and cattle. In some localities, and in certain years, control measures in the form of gassing and poisoned bait, now illegal, undoubtedly resulted in some

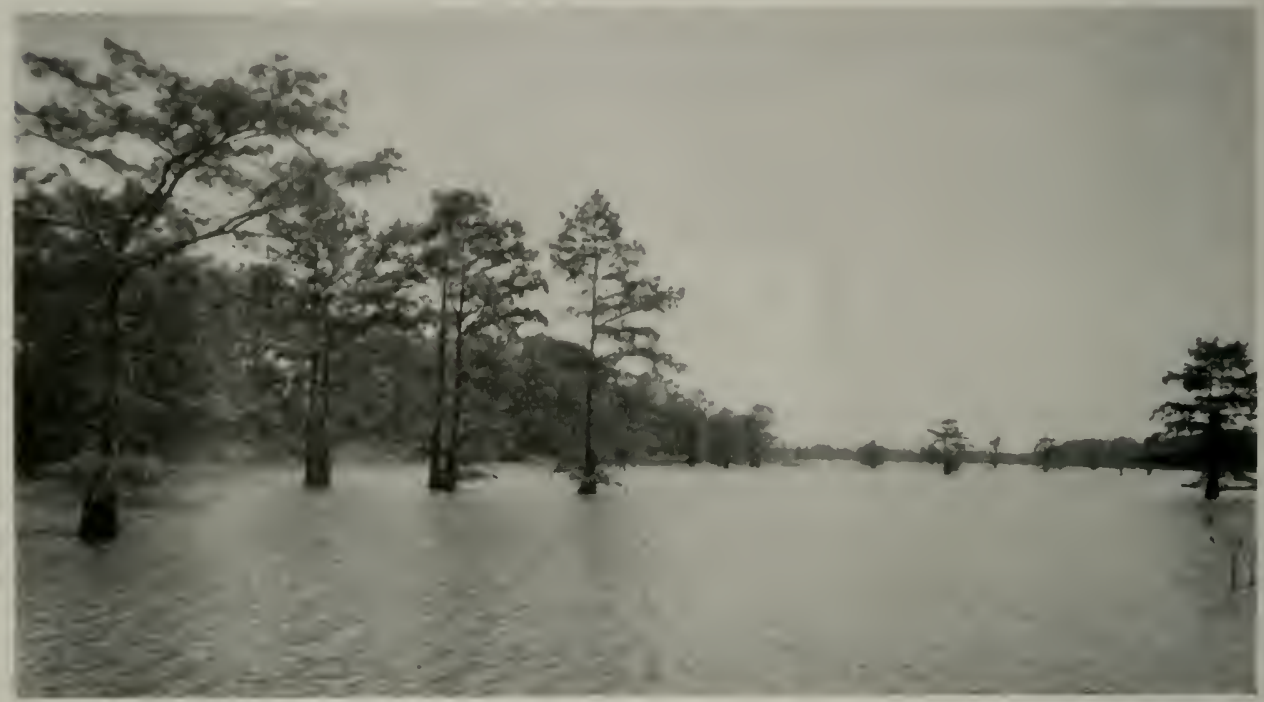

Fig. 28.-Horseshoe Lake, Alexander County. This and other oxbow lakes along the Mississippi, Illinois and Ohio rivers, supplying food, water and relative seclusion, offer potential if not acual otter rauge.

from their rodent-destroying value. 'Their dens constitute a hazard to livestock, and their ability to fight when cornered results in the crippling of dogs. Trappers in this state found them hard to hold, tough to skin and unprofitable, because most Illinois badgers have the coarse, "hair-badger" type of pelt. For these reasons there was little deliberate effort to trap them even in the years when badger trapping was legal, and hunters sought to avoid badgers because of the resultant fights and maiming of their dogs. Most of the badgers were taken incidentally to trapping for other animals. Still-hunters accounted for a part of the take. 'lraps set at the entrance of dens, mistaken by trappers for those of skunks, were most productive and a large part of the badger catch was so made.

'The most suitable badger habitat in 11linois appears to be rolling, sandy grassland prairie. Here the anmals dig innumerable dens and holes, partly in pursuit of rodents. Such activities may destroy some pasture area, in addition to being the cause of occasional hroken legs decrease in the badger population as well as that of skunk, woodchuck and other mammal species.

In view of the scarcity of the badger, the writers believe it to be worthy of full protection except under such circumstances as make control imperative.

\section{Coyote}

The coyote, according to Gregory (1936), was once plentiful in the Chicago region, later practically extirpated, "ind only recently beginning to appear cccasionally." Its present population in the state is very low, and, as determined by the survey, it appeared in the fur catch only in the Northwestern Sand Prairie. lt is, however, known to occur in other regions of the state. The tendency of the coyote to cross with dogs complicates its status considerably and partly accounts for the frequent reports of its occurrence. In many instances where such reports have been checked it was found that the animal involved was a police $\mathrm{dog}$, or occasionally some other kind. A number 
of records of recent date are given in the Mohr report.

In its present numbers, coyotes in themselves constitute little or no problem in Illinois, and many of the complaints popularly associated with them are in reality associated with wild or free-ranging dogs. In the event that coyotes become numerous, control measures may of course become necessary; any contemplated statutes and action relative to control of coyotes should include wild dogs.

The catch of 91 coyotes calculated for 1938-39 is believed to be based on too few data to be reliable. A catch of 25 per year is considered much more likely.

\section{Otter}

The otter, if not actually extirpated from Illinois, is present only in straggling numbers. The most recent records for the state are given in the Mohr report. This species has probably been of no appreciable importance in the Illinois fur trade since about 1900 .

In view of the several large rivers in and bounding the state, and particularly the large backwaters along the Illinois and Mississippi rivers that have formed behind navigation dams, there is undoubtedly some suitable otter range in the state, fig. 28. Numerous deep, wooded, clearwater sloughs making up part of such backwaters offer ample food, water and seclusion. With continued protection, which fortunately has been given this species since 1929, it would rot be surprising to see otters regain a part of their former Illinois range. It is not considered likely, however, that they will appear in sufficient numbers, at least in the near future, to justify an open season.

\section{Beaver}

The beaver has been of no appreciable importance in the Illinois fur trade since about 1850 . This species was complete$1 y$ extirpated in the state some time after Forbes (1912) had reported on the native animal resources of Illinois. It was reintroduced in 1935, and now appears to be established in Pope and Union counties. An account of beaver restocking, increase and spread is given in the Mohr report.

Except in certain southern Illinois lo-

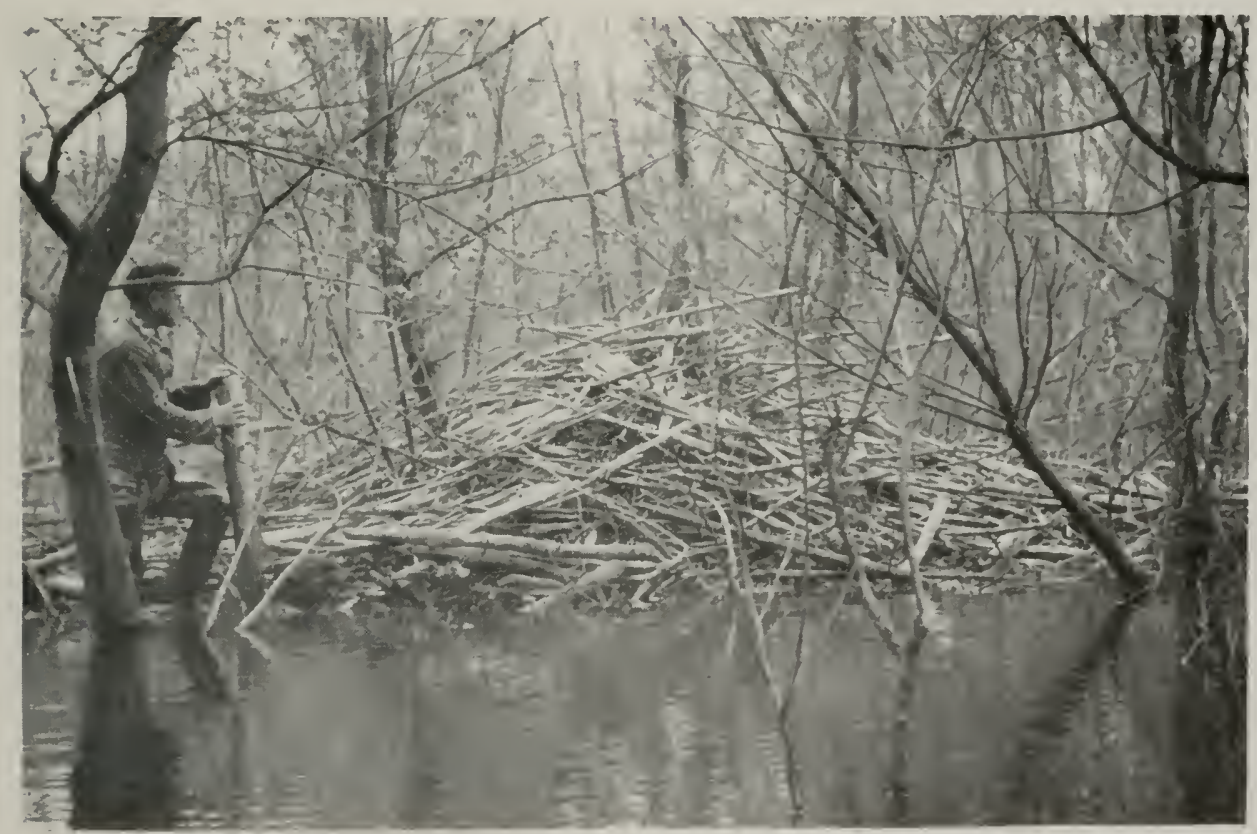

Fig. 29.-Beaver lodge at Wolf Lake, Union County, 1939. 'This bottomland stand of soft maple, cottonwood and willow was flooded in 1938. 
calities, hecause of agricultural interests there is little potential beaver range in the state. In the more heavily forested counties, however, particularly where small streams or lakes, and cottonwood, willow, soft maple and other hardwood stands occur, the heaver would find a bobcats may still occur in very low numbers or, in the event of suitable protection, they may appear there in the future. Several bobcats were reported taken in Alexander and Jackson counties in 19+2, from the forest-bluffs habitat along the Mississippi River. In view of the general ab-

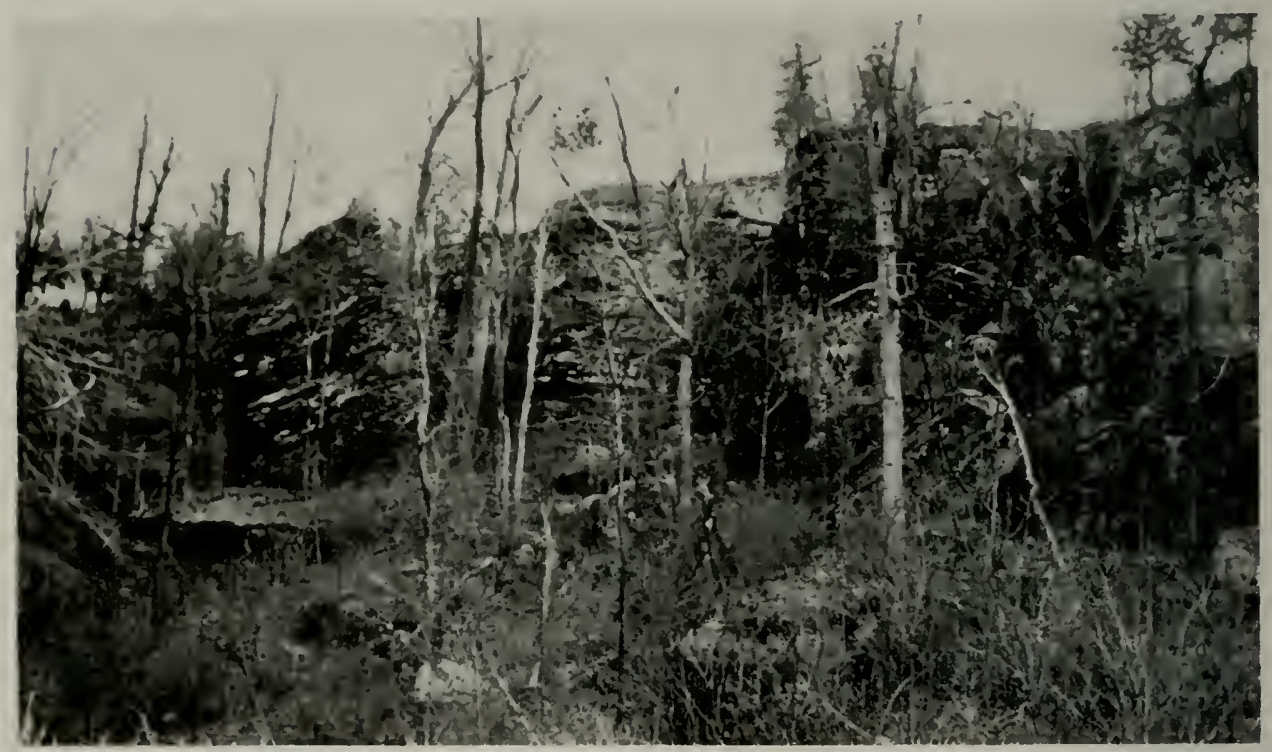

Fig. 30.-An example of Illinois terrain, Pope County, suitable for bobcat range. Semiwilderness forests and broken terrain offer territory attractive to this species.

limited amount of permanent habitat. One well-used beaver habitat was created in Union County by flooding a small hardwood timbered bottom, fig. 29. It is not improbable that cottonwood- and willow-bordered stripmine lakes would support beavers. There is, of course, no likelihood of this species regaining its former importance in the state.

\section{Bobcat}

'The bobcat, or wildcat, is another Illinois mammal now found in very low numbers. Decimation was rapid after 1910 because bobcats offer exciting sport, are condemned as destructive predators by farmers and many sportsmen, and require a semiwilderness habitat. 'The logging of cypress swamps in the southern tip of the state probably destroyed the last good bobcat range in lllinois. In several southern Illinois counties where sizable areas of forests and bluffs are found, fig. 30, sence of suitable range, it is likely that bobcats will never regain their former status, even in the more heavily timbered parts of the state. Other recent records of bobcat occurrence in Illinois are given in the Mohr report.

Bobcats, because of the very low value of the fur, have never been of any appreciable importance in the fur trade, Illinois or elsewhere.

\section{House Cat}

The house cat is now one of the most abundant carnivores in Illinois, as in many other states. Its ecological influence has never been adequately studied, but that it is an important predator in farm regions can hardly be doubted. No close estimate of the Illinois house cat population is made here, but one per household, rural and urban, is not an exaggeration. 'This would amount to over $1,500,000$ cats, of which at least half are free to range over game- 
producing areas. It is certain that a very large number of rodents are destroyed by these cats, and equally certain that thousands of song and game hirds and rabbits are also destroyed. The fur, while salable for a few cents per pelt, is of practically no importance in the trade. This circumstance further disqualifies the species as a worthy member of the fauna.

The writers recommend strongly a material reduction of the free-ranging house cat population and suggest shooting and trapping by conservation officials, sportsmen and trappers as the best method of effecting such reduction.

\section{TOTAL YIELD AND VALUE}

The foregoing sections have given in some detail the yield and value of each important Illinois fur animal during the two seasons covered by the survey. 'The discussion is continued in the following paragraphs, but with all species grouped and the state considered as a unit. For convenience and brevity, much of this information is presented in tables.

Any consideration of the yield and value of the total fur resource of Illinois should be prefaced by a discussion of fur prices. The average prices of the seven most important Illinois raw furs, 1909 through $19+2$, is shown in fig. 31 . With the exception of those for minks, prices during the seasons of 1938-39 and 1939t0 were about equal to, or at least not far above, those prevailing during the worst years of the recent depression. Based on the opinions of hundreds of Illinois furtakers, the fur catch has steadily declined

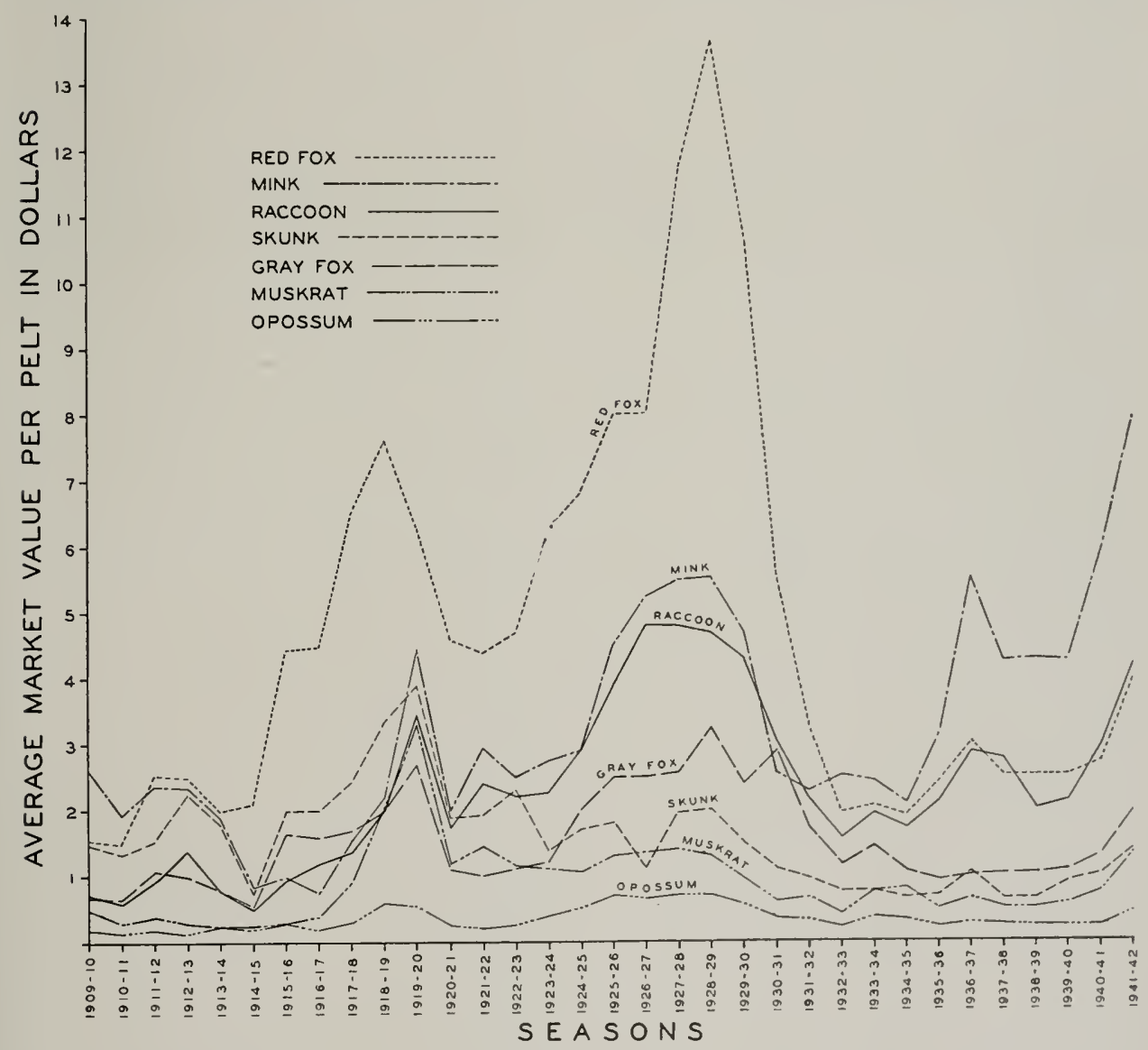

Fig. 31.-Average raw fur prices, Central States, for seven important species, 1909-10 through 19+1-+2. Sources of data: 1909-35, St. Louis Globe-Democrat, as adapted from Bennitt \& Nagel (1937); 1935-+2, Fur-Fish-Game raw fur market averages for No. 1 medium pelts. 
(1)

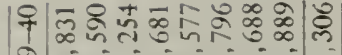

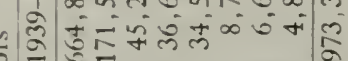

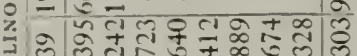

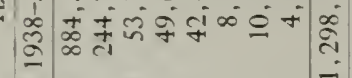

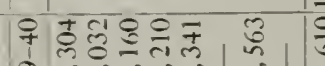

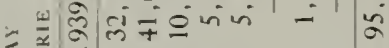

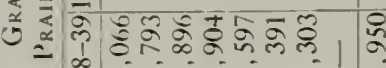
๙ิ)

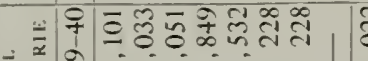
से

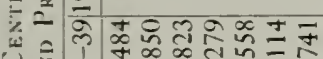

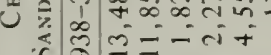

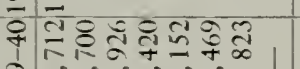

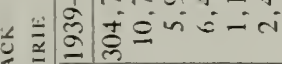
m

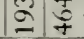

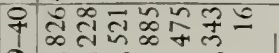

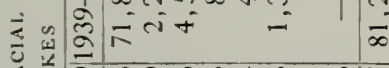
势

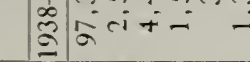

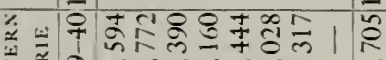

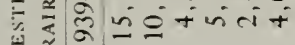

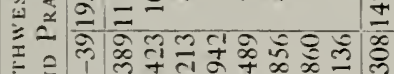
药

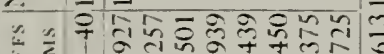

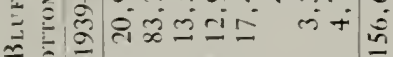
$\approx$ ले 2 -

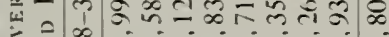
三

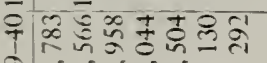
ش

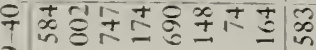
$\tilde{\sigma}=$

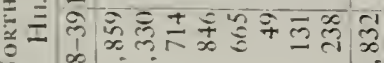

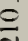
สू की ले

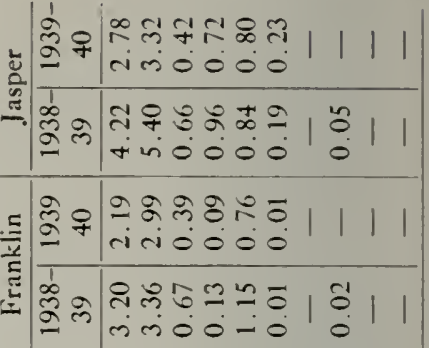

$\dot{\omega}$

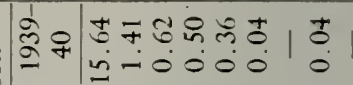

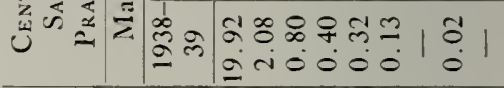

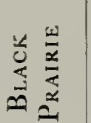

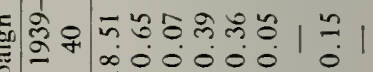

$\overline{2}$

空点

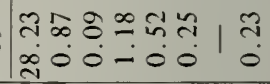

\begin{tabular}{|c|c|c|}
\hline & हूे & 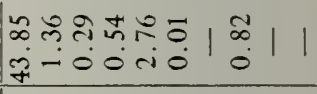 \\
\hline$\underline{z}$ & 㓂 & 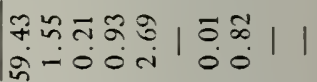 \\
\hline
\end{tabular}

\begin{tabular}{|c|c|c|}
\hline 4 & gू & 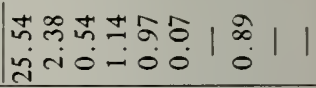 \\
\hline 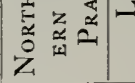 & $\underset{2}{\infty}$ & \\
\hline
\end{tabular}

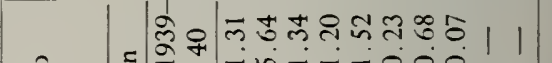

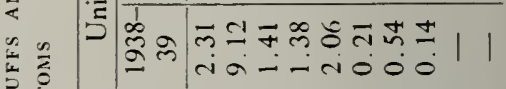

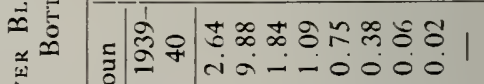

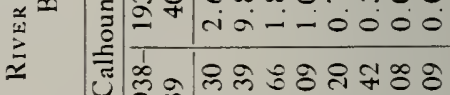
ũ z

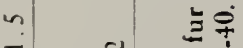


Table 17.-Composition of calculated lllinois fur catch, expressed for each region and each important species as per cent of total catch for 1938-39 and 1939-40.

\begin{tabular}{|c|c|c|c|c|c|c|c|c|c|}
\hline $\begin{array}{c}\text { FUR } \\
\text { SurveY } \\
\text { ReGion }\end{array}$ & $\begin{array}{l}\text { MUSK- } \\
\text { RAT }\end{array}$ & $\begin{array}{l}\text { Opos- } \\
\text { sum }\end{array}$ & MlNK & SKUNK & $\begin{array}{l}\text { RAC- } \\
\text { cooN }\end{array}$ & WEASEL & $\begin{array}{l}\text { RED } \\
\text { Fox }\end{array}$ & $\begin{array}{c}\text { Gray } \\
\text { Fox }\end{array}$ & $\begin{array}{c}\text { PER } \\
\text { CENT } \\
\text { OF } \\
\text { TotAL } \\
\text { Cotch }_{\text {ATC }}\end{array}$ \\
\hline $\begin{array}{c}\text { Northwest } \\
\text { Hills.... }\end{array}$ & 71.94 & 8.21 & 5.14 & 7.11 & 4.77 & 0.69 & 0.72 & 1.42 & 1.25 \\
\hline $\begin{array}{l}\text { Western Prairie } \\
\text { River Bluffs }\end{array}$ & 42.96 & 35.00 & 8.69 & 4.91 & 7.59 & 0.16 & 0.69 & 0.00 & 3.52 \\
\hline & 12.27 & 57.49 & 8.53 & 7.00 & 10.24 & 0.46 & 1.74 & 2.27 & 16.83 \\
\hline Sand Prairie. & 83.08 & 6.69 & 2.80 & 2.98 & 1.81 & 2.16 & 0.43 & 0.05 & 11.98 \\
\hline Glacial Lakes. . & 89.60 & 2.52 & 4.73 & 1.28 & 0.43 & 1.42 & 0.01 & 0.01 & 8.31 \\
\hline $\begin{array}{l}\text { Black Prairie. } \\
\text { Central Sand }\end{array}$ & 90.66 & 2.95 & 1.71 & 3.05 & 0.31 & 0.74 & 0.58 & 0.00 & 37.36 \\
\hline Prairie... . & 84.11 & 8.25 & 1.61 & 2.13 & 3.36 & 0.14 & 0.40 & 0.00 & 10.60 \\
\hline Gray Prairie. & 34.86 & 42.43 & 10.00 & 5.25 & 6.05 & 0.17 & 1.24 & 0.00 & 10.15 \\
\hline $\begin{array}{l}\text { Per Cent of } \\
\text { Total } \\
\text { Catch... }\end{array}$ & 68.19 & 18.31 & 4.36 & 3.80 & 3.39 & 0.78 & 0.76 & 0.41 & 100.00 \\
\hline
\end{tabular}

during at least the last two decades. In about 1920 , when catches were larger and prices as high or higher, the total annual worth of Illinois raw furs was undoubtedly in excess of the income shown for the seasons of 1938-39 and 1939-40.

Prices have a very important bearing on catches of certain species. Red fox pelts were unusually valuable during the period 1927-30, but by 1932 had dropped nearly to the value of raccoon pelts, resulting in greatly reduced hunting and trapping pressure on red foxes. This condition may explain in part the increase in the numbers of these foxes during the last decade. It is known that comparatively high red fox populations have prevailed since about 1933 .

Despite low prices, the muskrat take has continued heavy since the era of high prices. This is due to the comparative abundance of the animals and the ease with which they are trapped and handled. The relatively high level of mink fur prices since 1935 is undoubtedly responsible in large measure for the severe reduction in numbers of this valuable species. Low prices during recent years on other furs, particularly on those of opossums and foxes, undoubtedly resulted in

Table 18.-Calculated value of Illinois raw furs per square mile in 10 sample counties, 1938-39 and $1939-40$.

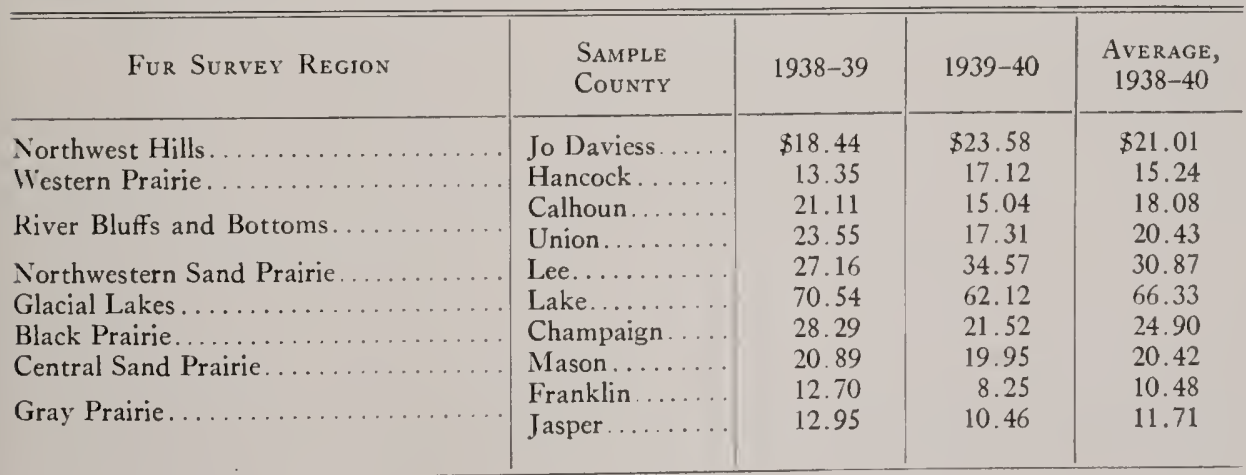




\begin{tabular}{|c|c|c|c|c|c|c|c|c|c|}
\hline 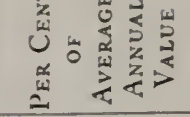 & $\underset{-}{+}$ & $=$ & $\stackrel{0}{\stackrel{0}{\sim}}$ & $\begin{array}{l}8 \\
=\end{array}$ & $\begin{array}{l}\widehat{D} \\
\infty \\
\infty\end{array}$ & $\begin{array}{l}\cong \\
\text { ले }\end{array}$ & $\begin{array}{l}\infty \\
\stackrel{0}{a}\end{array}$ & $\begin{array}{l}\text { gे } \\
=\end{array}$ & $\begin{array}{l}8 \\
8\end{array}$ \\
\hline 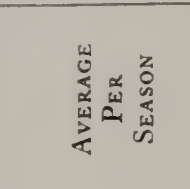 & 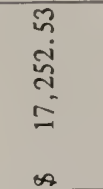 & 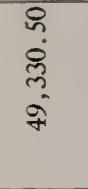 & $\begin{array}{l}\infty \\
\stackrel{\infty}{\infty} \\
\infty \\
\sim \\
\sim \\
\infty \\
\infty \\
\sim\end{array}$ & 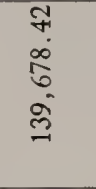 & $\begin{array}{l}\text { R. } \\
0 \\
0 \\
0 \\
0 \\
0\end{array}$ & 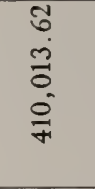 & 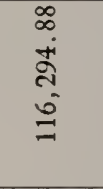 & $\begin{array}{l}n \\
\alpha \\
o \\
o \\
\dot{ \pm} \\
\dot{J}\end{array}$ & 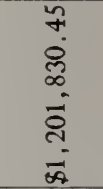 \\
\hline 壱 & 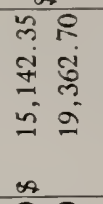 & 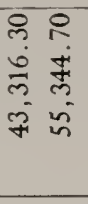 & 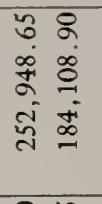 & 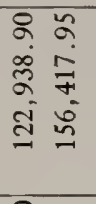 & 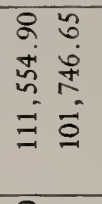 & 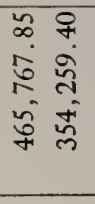 & 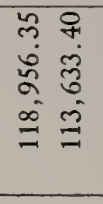 & 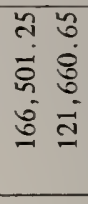 & 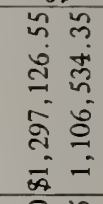 \\
\hline $\begin{array}{l}x \\
0 \\
0 \\
x \\
x \\
0 \\
0 \\
0\end{array}$ & 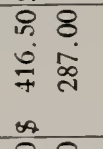 & 11 & 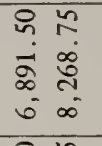 & 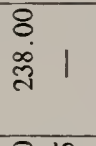 & 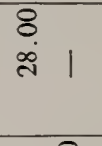 & 11 & 11 & 11 & 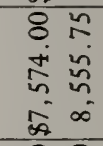 \\
\hline 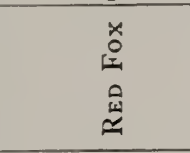 & 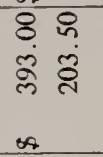 & $\begin{array}{ll}8 & 8 \\
\dot{0} & \text { ऽ } \\
\stackrel{\infty}{\infty}\end{array}$ & 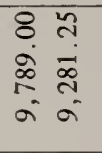 & 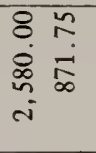 & $\begin{array}{l}8 \\
1 \\
+\end{array}$ & 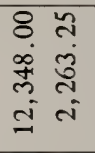 & $\begin{array}{ll}8 & 8 \\
\text { तु } \\
\text { तิ } \\
\text { i }\end{array}$ & 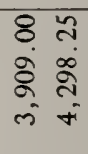 & 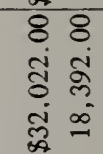 \\
\hline 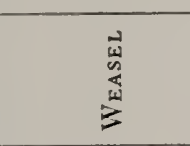 & $\begin{array}{l}\infty \\
\stackrel{2}{a} \\
= \\
\infty \\
\infty\end{array}$ & $\begin{array}{l}8 \\
\text { in } \\
\text { \% }\end{array}$ & 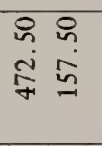 & 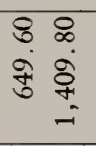 & 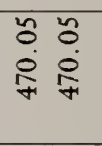 & 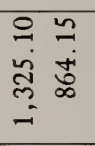 & $\begin{array}{l}8: \\
\text { के व }\end{array}$ & $\begin{array}{ll}n & \\
\infty & \\
\infty & 1\end{array}$ & 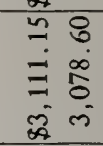 \\
\hline 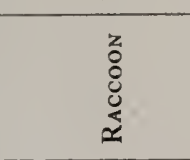 & $\begin{array}{l}8 \\
8 \\
\dot{0} \\
\dot{m} \\
- \\
-1 \\
-1\end{array}$ & 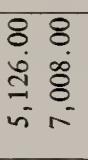 & 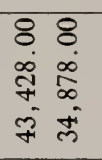 & $\begin{array}{ll}8 & 8 \\
\infty & \infty \\
\infty & \infty \\
\alpha & \infty \\
+ & +\end{array}$ & $\begin{array}{ll}8 & 8 \\
\infty & 0 \\
\infty & 0 \\
0 & 0\end{array}$ & 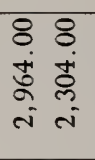 & 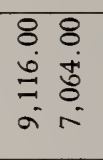 & 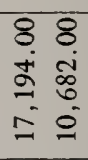 & 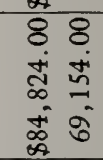 \\
\hline 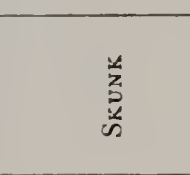 & 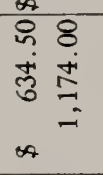 & 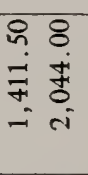 & 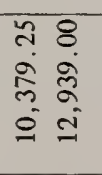 & $\begin{array}{ll}0 & 8 \\
0 & 0 \\
0 & 0 \\
0 & 0 \\
i & \text { in }\end{array}$ & 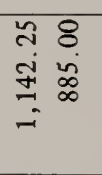 & 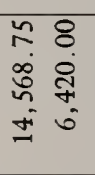 & 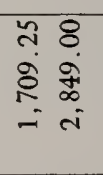 & $\begin{array}{ll}8 & 8 \\
\infty & 0 \\
0 & 0 \\
\text { ni } & \\
\text { ni }\end{array}$ & 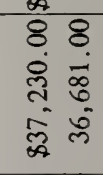 \\
\hline 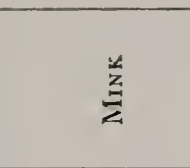 & 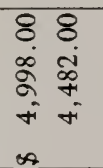 & 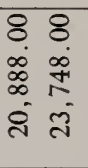 & 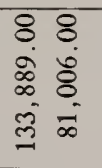 & 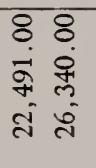 & 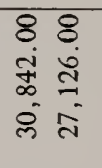 & 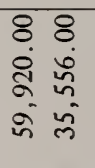 & 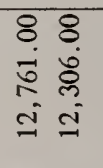 & $\begin{array}{l}8 \\
88 \\
1 \\
1 \\
8 \\
8 \\
8 \\
8\end{array}$ & 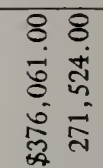 \\
\hline $\begin{array}{l}\text { a } \\
\vdots \\
0 \\
0 \\
0 \\
0\end{array}$ & 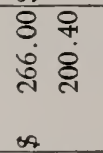 & 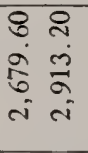 & 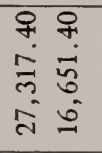 & 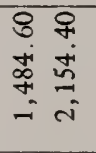 & $\begin{array}{ll}8 & 8 \\
\infty & 0 \\
0 & \vdots \\
\vdots & 4\end{array}$ & 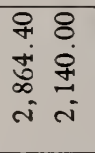 & $\begin{array}{ll}8 & 8 \\
0 & 0 \\
0 & 0 \\
0 & 0 \\
1 & =\end{array}$ & $\begin{array}{l}B \text {; } \\
\infty \\
0 \\
0 \\
= \\
= \\
=\end{array}$ & 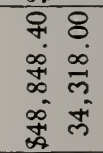 \\
\hline 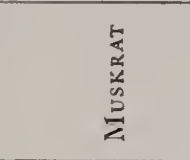 & 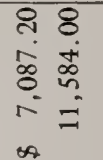 & 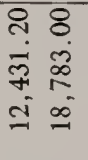 & \begin{tabular}{ll}
8 & 8 \\
1 & \\
0 & \multicolumn{1}{c}{} \\
2 & 0 \\
0 & 0
\end{tabular} & 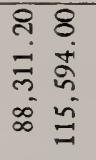 & 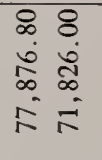 & 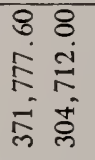 & 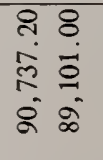 & 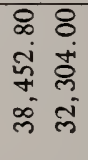 & $\begin{array}{l}88 \\
80 \\
0 \\
\% \\
0 \\
0 \\
0 \\
0\end{array}$ \\
\hline $\begin{array}{l}3 \\
0 \\
0 \\
w \\
w \\
w \\
w\end{array}$ & 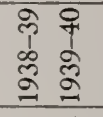 & 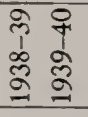 & 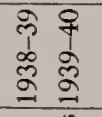 & 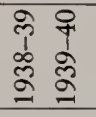 & 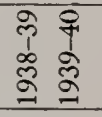 & 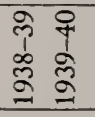 & 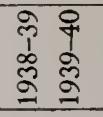 & 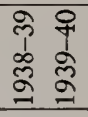 & 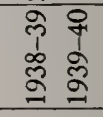 \\
\hline 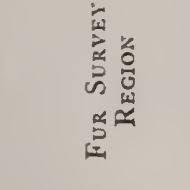 & 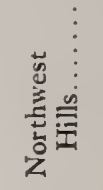 & 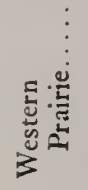 & 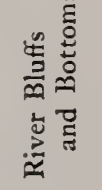 & 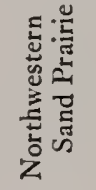 & 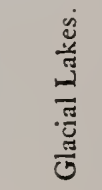 & 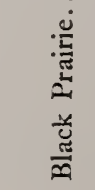 & 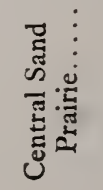 & 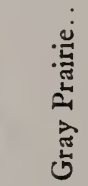 & 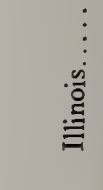 \\
\hline
\end{tabular}


some increase in populations, but their net effect on these populations is difficult to evaluate. Studies of extended duration on representative areas are necessary before the full effect of prices and various other economic and social factors can be determined.

Of the factors other than price that may affect the fur catch, the most important are weather, employment and the degree of prosperity among rural people generally. The effect of both employment and rural prosperity is apparent; during industrial booms, especially in mining and lumbering, or during eras of good farm prices, potential trappers are not inclined to follow the uncertain recourse of furtaking for a livelihood. This reference to farmer-trappers chiefly concerns tenants, share-croppers and small farm owners in southern or southwestern Illinois. Few landowners in the more prosperous farm regions give any time or thought to the fur crop, since it is insignificant in comparison with their main farm activities.

As discussed previously, there has been a pronounced decline in farm-boy trapping in Illinois. The skill of older professional trappers offers discouraging competition to boys, who are now concerned with school and related activities.

The effect of weather on the catch is highly important. Mild weather and open water usually result in increased catches, since traps placed on logs, in trails or at the edge of lakes and streams do not freeze down, and every night is a "catching" night. Extreme drought, resulting in dried-up water courses, serves to concentrate muskrats, minks, and probably other species, on areas where water is available. Under such conditions the bulk of the catch may be made by relatively few trappers, while fur-takers without trapping water often hang up their traps for the season or until heavy rains fall. Dry conditions also make for poor trailing and consequently low night catches of raccoons, opossums, foxes and other fur animals. Very deep snow, sleet and floods are also detrimental to good catches. Cold weather induces hibernation in raccoons and skunks, and reduced activity in certain other species. On the other hand, warm weather probably results in maximum travel on the part of fur animals and therefore increased chance of being taken in traps. Unseasonably warm weather may result in some spoilage of pelts. Under certain conditions, especially in the Glacial Lakes Region and on the Illinois River marshes, ice a few inches thick is conducive to good muskrat trapping.

In tables 15 and 16 , respectively, the calculated total and average per-squaremile catch of Illinois furs is given by species and regions for both years covered by the survey. In table 17 , these data are expressed in per cent for both species and regions, and for the state as a whole. In table 18 , the calculated income value of the fur resource per square mile in sample counties is summarized; and, in table 19, the value is expressed in dollars for both species and regions, and in per cent for regions. Table 20 , comparing catch with value, shows wide variation between total value and the total number of pelts for the various fur animal species. Similarity in percentages relating to catch and value for the same regions, tables 15 and 19 , is due to compensating factors between number and average pelt value of species. The data in tables 16 and 19 are taken directly from the preceding tables dealing with specific animals.

The value of the fur resource in Illinois as given in table 19 for 1938-39 and $1939-40$ is probably lower than the average annual income. How much lower it was than the average for the previous 20 years is not known. The total income for 1938-39 was $\$ 1,297,126.55$, as calculated from sample data; for 1939-40, $\$ 1,106$,534.35 , derived in the same manner. These data represent an average income of $\$ 1,201,830.45$ per season.

As stated in a previous section of this paper, the raw fur income is derived practically without investment or management, and at no harvesting expense except time and the cost of trappers' supplies. The investment, capitalized at 4 per cent, required to yield a comparable annual income may be calculated by using the standard formula:

$$
\begin{aligned}
& \text { Capital }=\frac{\$ 1,201,830.45}{0.04}, \\
& \text { or } \$ 30,0+5,761.25
\end{aligned}
$$

When the lower-than-average incomes of 1938-39 and 1939-40 are taken into 
Table 20.-Calculated catch and value of Illinois furs for two seasons, 1938-39 and 1939-40.

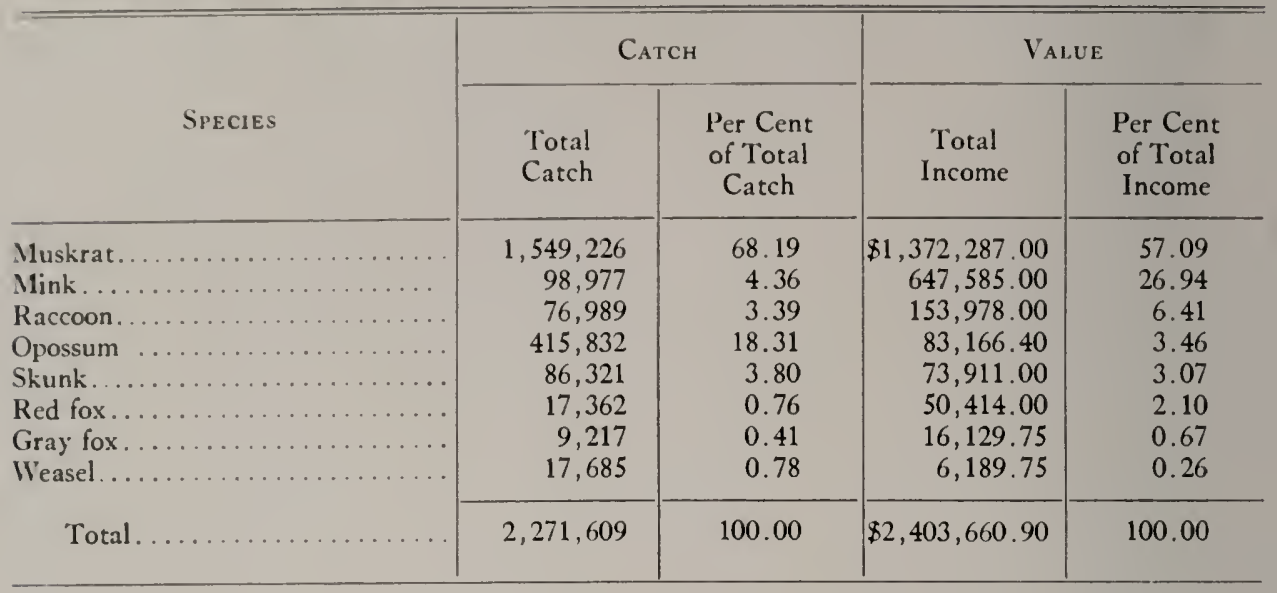

consideration, the capital value of the Illinois wild fur resource is calculated to be about $\$ 35,000,000$.

\section{ILLINOIS FUR TRADE}

During the 1939-40 fur season, 43 buyers and 5 large fur companies were visited in an effort to determine variations in fur quality, methods of handling and methods of selling Illinois furs. Fig. 32 shows the location of the fur buyers visited. Four of the fur companies are well known St. Louis firms; and the fifth, located in Chicago, does the largest fur business in Illinois. 'Through the cooperation of both buyers and dealers, considerable information was obtained on various phases of the fur trade in the state.

\section{Quality}

Our data are based on general observations, dealers' estimates and many personal inspections of furs. We are not able to give many of the causes for the variation found in quality. 'This attribute of fur is fundamentally concerned with food, injury, age and season, and could not be studied experimentally in the brief survey made.

Fur quality is ordinarily indicated by several terms, among which "prime," "unprime," "kit" and "damaged" are most common. Color has an important bearing on quality. Furs are usually graded according to a numerical series: "No. 1," "No. 2," "No. 3" and "No. 4," in which size is usually expressed as extra large, large, medium and small. A No. 1 extra large pelt represents the highest grade and value. No. 1 furs are prime and well furred; No. 2's are semiprime; No. 3's are damaged and extremely unprime; and No. t's are kits, summer pelts and trash.

Illinois muskrats, as characteristic of the species in North America, do not become fully prime until January; hence, a large part of the catch is more or less unprime and is graded as "falls." Muskrats are frequently graded as "falls," "winters" and "springs," the last class being the most valuable. It is significant that on most of the large muskrat marshes under management in Illinois trapping is not permitted until mid December.

Fall trapping for muskrats results in the taking of kits, which are immature animals usually worth only a few cents. 'Their pelts are graded separately and sold as "linings." Kits made up about 8.5 per cent of the total Illinois muskrat catch in 1939-40. In that year, kits composed about 15 per cent of the opossum catch, 10 per cent of the raccoon catch, 4 per cent of the skunk catch and 2.5 per cent of the mink catch. Weasels, minks and skunks graded out the highest per cent of No. 1's, followed in order by raccoons, gray foxes, muskrats, red foxes and opossums.

According to dealers and fur buyers, in the years of the survey about 11 per cent of all Illinois furs were damaged. Of this volume, an undeterminable small percentage was trash. The per cent of dam- 
aged furs amounted to 7,13 and $1+$ per cent for the northern, central and southern zones, respectively. Damage was probably most often caused by dogs, and was common among pelts taken by night hunters. The percentage of damaged furs showed a correlation by zones with the amount of night hunting. Other causes of damage were carelessness in skinning and stretching, wherein pelts were cut or torn; fighting by the animals before or after they were taken in traps; and spoilage. Damage from fighting, which in some species shortly precedes mating activity, was common late in the season. Minor types of damage, from the standpoint of volume, were "curling," "singeing," "rubhing" and "fading," all usually a result of wear or mechanical injury and not apparent until late in the season. Musk-

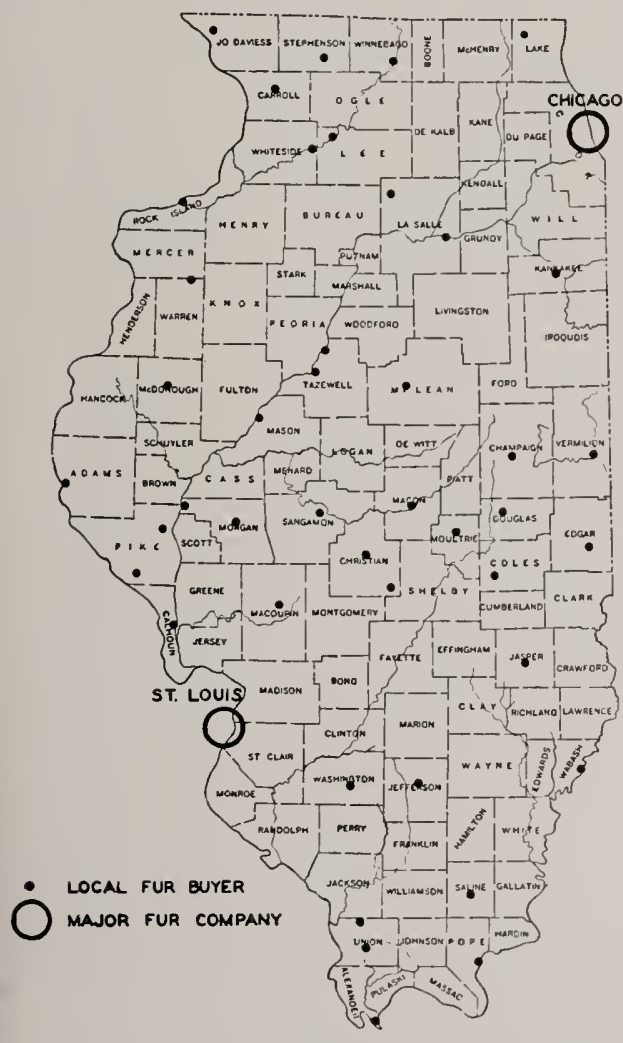

Fig. 32.-Location of major fur companies and local fur buyers interviewed in determining quality of Illinois furs and practices employed in the state's fur trade. One major company in Chicago and four in St. Louis, Mo., are represented. rats showed by far the largest volume of damaged fur. Opossums showed the highest percentage. This was due probably to the large volume of opossum furs taken with dogs and to carelessness in skinning and stretching these low-priced pelts. Other species such as raccoons and red foxes were occasionally damaged at the time of capture or in handling. A large part of damage in all species is preventable.

In Illinois minks, an inferior grade known as "cotton" is found. "Cotton" minks are usually detected by blowing into the fur side of the pelt, which discloses the grayish color of the under fur; some skins are so white that the defect is discernible from a distance. There appeared to be a distinct increase in the per cent of "cotton" minks for 1939-40 over the preceding season. Dealers reported that in the northern zone 3.9 per cent, in the central zone + per cent and in the southern zone 0.3 per cent of the pelts were of "cotton" quality. The greatest number was reported from the central Illinois River valley, particularly from the vicinity of Havana. Here, one dealer stated that "cotton" minks made up 20 per cent of the catch, but this estimate may be too high. A large fur company, which receives a great deal of Illinois fur, reported that of this state's mink catch 1.46 per cent in 1938-39 and 5.5 per cent in 1939t0 were "cotton" skins. The cause of the defect and the reasons for its increase in $1939-40$ are not known. Reduction in value varies with the amount of white, but averages about 50 per cent.

Illinois skunks, which prime early, grade largely to No. I's and No. 2's; they are further classified according to the length and width of the two white dorsal stripes. These classifications are given in table 21. Pelts containing the smallest amount of white are the most valuable.

As shown in table 21, the highest percentage of dark skunks in Illinois came from the southern zone, although by far the largest skunk catches were made in the northwestern regions of the state. The northern zone produced the highest percentage of broad and narrow stripe pelts.

Mange was observed on red fox, raccoon, opossum and skunk pelts. It probably occurred on others. 'The infestation 
for all species ran less than 1 per cent. A few trappers reported taking lice-infested minks, which were thinly furred and of poor quality. Some of the mink pelts showed wounds, evidently the result of chewing or scratching irritated spots.

Some account was taken of unusual skins observed in various fur-receiving and storage rooms, or reported by dealers. Such pelts usually bring less than furs of muskrats at the rapid rate of 60 per hour.

In Illinois, most trappers visit their traps daily, usually as early in the morning as possible. Unlike north-woods trappers, few have lines so long as to require more than a half day to cover them. Lines run early in the day result in fewer escapes, less damaged fur, less theft and, of course, much less suffering on the part of captured animals. Furbearers still alive

Table 21.- Percentages of raw skunk furs of five different qualities, judged on the basis of color alone, from the three Illinois trapping zones, 1938-39 and 1939-40. Figures furnished by fur dealers.

\begin{tabular}{|c|c|c|c|c|c|}
\hline ZoNe. & $B_{L A C K}$ & Star & Short Stripe & Narrow Stripe & BROAD STRIPE \\
\hline $\begin{array}{l}\text { Northern } \ldots \ldots \ldots \\
\text { Central ........ } \\
\text { Southern........ }\end{array}$ & $\begin{array}{l}4 \\
3 \\
9\end{array}$ & $\begin{array}{r}3 \\
7 \\
14\end{array}$ & $\begin{array}{l}22 \\
35 \\
29\end{array}$ & $\begin{array}{l}39 \\
32 \\
25\end{array}$ & $\begin{array}{l}32 \\
23 \\
23\end{array}$ \\
\hline
\end{tabular}

normal color, but it should be remembered that they make up an exceedingly small part of the total catch. This information may be presented as follows:

Muskrat-albino, and a dappled color. Opossum-albino, white (not albino), black and rufus.

Raccoon - albino, cinnamon-albino, black, and yellowish.

Skunk-albino, russet, and broad stripe extending around under tail with white spots on abdomen.

Mink-albino, sorrel, and "cotton."

Coyote-one odd pelt evidently resulting from coyote-dog cross.

\section{Handling}

Despite the more or less standardized system of grading furs according to size and quality, there is a surprising laxity among trappers in handling skins, which has very important effects on quality. Carelessness, most often characteristic of boy and nunprofessional fur-takers, is due to several reasons: lack of individual skill; rush of work, particularly during the early part of the season; and ignorance or shiftlessness. Professional trappers take pride in handling their catches and some of them possess great skill in skinning and stretching, fig. 33. Many trappers are able to skin a muskrat properly in +5 seconds and to stretch it in less time. Some experienced trappers regularly skin are killed by the trapper, usually by drowning if convenient, but often with a hatchet, club or small rifle. Most skunks are shot and most opossums are dispatched by breaking the neck with a stick or hatchet handle placed across it. Mudcoated animals are washed, either in a pond or creek or under a faucet. Skinning, except by the most successful muskrat trappers along the Illinois River, is seldom done in the field. Skinning and stretching are thus usually reserved as afternoon or evening work.

All Itlinois furs except raccoon are "cased," that is, not split down the belly. Stretching cased skins is by means of boards or metal frames of such sizes and shapes as to fit the various sizes of skins. Muskrat pelts may be stretched on wire frames, purchased for a few cents each, or on shingles, willow boughs or other devices. Wooden forms are usually employed for the larger species such as foxes. Raccoons, except the better quality northern skins, which grade as "collar" coons, are usually stretched open, and a very large percentage are nailed on barn doors or comparable stretching surfaces. The removal of excess flesh and fat from freshly skinned pelts is necessary to prevent spoilage and "grease burning." 'The survey disclosed that many trappers were careless in this phase of pelt care. The resultant loss probably amounted to 10 per cent of the value of the annual catch. 
Drying or curing is highly important in preparing raw furs for the market. A cool, airy, dry room or attic is the best type of drying place. Muskrats require only two or three days to dry sufficiently for shipping; foxes may require a week or more. Raw furs should never be dried in the sun, before a fire or stove, or treated with salt or other curing preparations.

Trappers operating on a large scale sometimes market their catch unskinned. This is convenient and allows more time for trapping. The catch of the average trapper in Illinois, however, does not warrant such practice. Prompt skinning is necessary since animals left to freeze and thaw quickly deteriorate, thereby greatly reducing fur quality.

Too much emphasis cannot be placed on the need for proper handling of furs.
Dealers and large fur companies have emphasized the need for care in skinning, stretching and fleshing, and have promoted such care by awarding daily and weekly cash prizes for the best handled pelts of all important species. Most large companies provide detailed handling instructions, free for the asking.

Very little use is now made of the skinned carcasses of fur animals, although efforts are being made to develop markets for Illinois muskrat meat. Such development would provide annually about $1,000,000$ pounds of food now almost entirely wasted. Fox farmers in northern Illinois find limited use for skinned animals in the preparation of feed. There is a slight demand, especially in southern Illinois, for opossum and raccoon meat at low prices. Most of the carcasses are fed

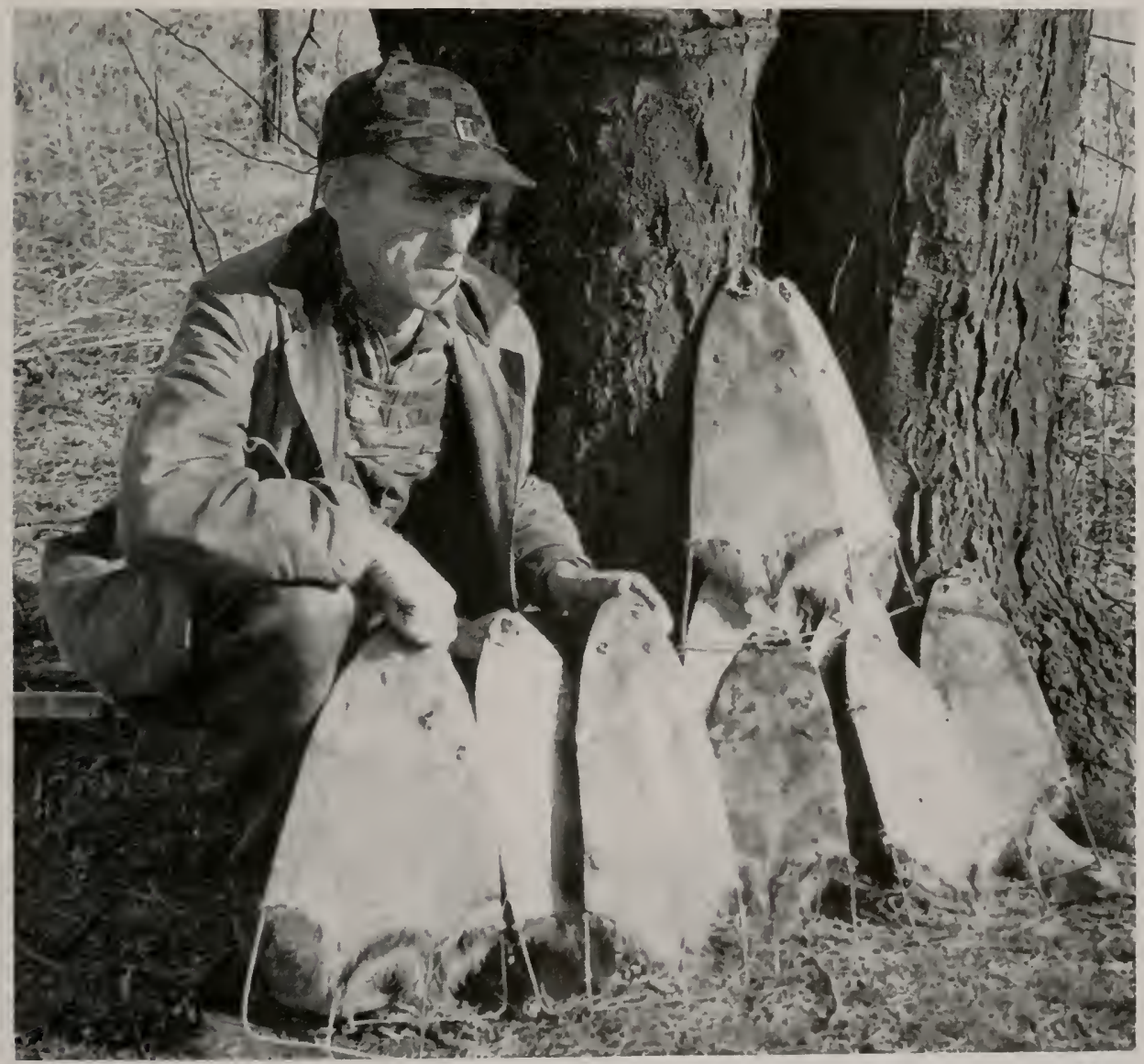

Fig. 33.-An early season catch of well-handled muskrat skins from Vermilion County. The freshly skinned pelts have been stretched and are being dried on wire frames. 
to hogs or are buried or burned. Large fur companies usually save the fatty residues from pelts in Heshing operations.

\section{Selling}

During the seasons of the survey, approximately to per cent of the annual Illinois fur catch was shipped directly to large fur houses, 50 per cent taken to local dealers and 10 per cent picked up at trappers' camps or residences by traveling buyers or representatives of local dealers. Most local dealers finally disposed of their collections to the larger auction houses. On the basis of the best estimates available, about 75 per cent of the total Illinois catch ultimately went to St. Louis and Chicago and the remainder to eastern fur centers.

After the opening date of the Illinois fur season there is a rapid turnover of the catch, heginning with the trapper who disposes of his skins to traveling buyers, local dealers, or the large fur houses, and terminating when the furs have been graded and sorted into large uniform lots for auction to manufacturers. Auctions are usually held on the floors of the large fur companies.

Some local dealers prefer to handle freshly skinned but unstretched pelts, or even unskinned animals, brought in daily by trappers and hunters or collected daily by traveling representatives of the dealers. Dealers buying unskinned animals employ one or more skinners to handle the pelts. 'This practice results in greater uniformity' in handling and somewhat better sales prices. Of the +3 local dealers contacted, 28 preferred to buy stretched and dried pelts, 11 preferred freshly skinned but unstretched pelts, 2 preferred to do their own skinning and 2 had no preference.

No special attempt will be made here to discuss the illegal phases of fur-taking and marketing. The chief evil appears to be before- and after-season trapping. Preseason furs are held until after the season opens, and, other than being more unprime than legal furs, they can scarcely be detected when sold. That early trapping is common was clearly determined during the survey, and it appeared to be especially prevalent in certain parts of southern Illinois. It was apparent that some local huyers encouraged the practice and in this manner attempted to corner the local trade.

Some furs taken after the season closes, in the 10-day postseason interval during which furs may be legally held, are harder to dispose of than preseason furs. A common practice seems to be to carry them into a bordering state having a later season, where they are sold as local furs. The large fur companies in St. Louis and Chicago earnestly encourage legal trapping, but have no practical means of determining the legality of furs purchased either by shipment or in over-the-counter transactions.

\section{SUMMAR Y}

1. The Illinois wild fur resource was studied intensively in the field from June 1,1939 , to June $30,19+0$. This paper, prepared subsequently, is the final project report.

2. In the previous literature on Illinois fur animals, which deals mainly with their habits and predator relationships, estimates of the value of the fur resource, prior to about 1930 , were lower than the actual value is believed to have been.

3. The main objective of the survey was the determination of facts on which to base biologically sound trapping laws and other regulations pertaining to Illinois fur animals. Such facts involved the habitat requirements of the fur animals, the annual yield and income by species and localities, the portion of furs taken by trappers and by hunters, the number of licensed and unlicensed furtakers, methods of trapping, hunting and marketing furs, and fur animal cycles.

t. For convenience in sampling, Illinois was divided into eight survey regions, division being on the basis of soil, forest cover, drainage, topography and similar features. Representative sample counties were selected in each region, and survey strips one mile wide were run in an eastwest direction at uniform intervals across each. Approximately 11 per cent or more of each sample county was included in the strips. In the eight regions the sample varied from 0.67 per cent to over 9 per cent of the total area. For the state it amounted to 1.7 per cent of the total area. Each household on the sample strips was visited, and information pertaining to fur- 
taking on the part of all residents was uniformly recorded. Return trips and much night and week-end work were necessary in order to obtain all records.

5. In 1938-39, the calculated number of Illinois fur-takers, defined as individuals taking furs by their own efforts, was 29,431 ; in $1939-40$, the total was 27,021 . About 9,500 individuals each year took furs by hunting; all other fur-takers were trappers.

6. Fur-taker density in the eight regions varied from 0.33 to 0.83 per square mile, the greatest density being in the Glacial Lakes Region north and west of Chicago. The lowest density was in the west-central part of the state, between the lllinois River and the Black Prairie. For the state as a whole, density was about one fur-taker per 2 square miles.

7. Illinois trapping laws in 1938-39 were staggered both by zones and species; in 1939-40, they were staggered only by zones. The basic season was from Nov. 15 to Jan. 15 or 31 . In 1938-39, 15,472 licenses were sold; 18,277 were sold in 1939-40. Slightly more than one-half of the lllinois fur-takers in the two seasons were licensed. Unlicensed fur-takers were mainly legal operators on their own or rented land, where they were exempt from the license requirement. The number of fur-takers operating illegally was difficult to determine, but apparently varied by localities from almost none to 10 per cent or more of the total number.

8. Average raw fur prices for the two seasons, determined by averaging amounts received for a large series of pelts of each species from each zone, were low.

9. A summary of the catch, value, population fluctuation, popularity and other pertinent data relating to lllinois fur animals for $1938-39$ and $1939-40$ is given in table 22 .

10. Badgers and coyotes occurred in such small numbers that the sampling methods used did not give reliable data. Otters, beavers and badgers were accorded full protection. Beavers, reintroduced in southern Illinois in 1935, were found to be increasing in numbers. Otters and bobcats occurred in very low numbers, if at all. House cat numbers were estimated at $1,500,000$, at least one-half of which were free to hunt out of doors the year around. 'This species, perhaps the most common predator in the state, was of practically no value in the fur trade.

11. Individual animals of any of the lllinois fur species may be more injurious than beneficial to man, but no species could be classed as wholly destructive. Foxes and weasels, under conditions present at the time of the survey, were probably the most destructive fur animal species in the state. Control of destructive individuals, if necessary involving killing at any time of year, is advocated but, when possible, trapping and hunting in season are reconmended as control methods. Usually the services of experienced trappers can be enlisted.

12. Habitats for most Illinois fur animals appeared to be deteriorating more or less steadily at the time of the survey. The most noticeable example was the raccoon habitat, which was being subjected to heavy lumbering. Drainage of lowlands was reducing the area of muskrat and mink range, but the use made of ditches by these two species partly compensated for this loss. Minks had been sharply reduced in numbers during the preceding decade because of the continued high prices of the fur. Opossums and foxes seemed well adapted to conditions existing at the time of the survey, and their numbers, due partly to low fur prices, were stationary or were increasing.

13. Methods of taking furs varied by species and regions. More than threefourths of the annual fur take was by trappers; the remainder by hunters, operating day or night, with or without dogs. Night hunting was commonest in forested regions, because raccoons and opossums, the two species taken most by night hunters, were most abundant in this habitat. Farm-boy trapping showed a material decline in Illinois; a large part of the fur catch was by experienced trappers who averaged 33 years old. The volume of the catch was found to be greatly influenced by weather, fur prices and industrial conditions.

14. The average annual value of the Illinois fur resource in 1938-39 and 1939t0, summarized in tables 15 to 20 , inclusive, was over $\$ 1,200,000$, which represents a capital value of over $\$ 30,000,000$ at + per cent interest. 'The fur income for the two seasons reported on was un- 


\begin{tabular}{|c|c|c|c|c|c|c|c|c|c|}
\hline \multirow{2}{*}{ 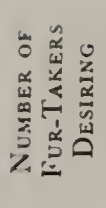 } & 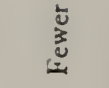 & $n a$ & 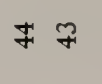 & $+r$ & in & -- & $=\infty$ & $\$$ & बి \\
\hline & 产 & त्ल ल ल & స్ సొ లొ & 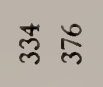 & 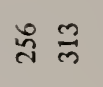 & ळొ & లి 3 & 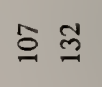 & 㖼 \\
\hline \multirow{3}{*}{ 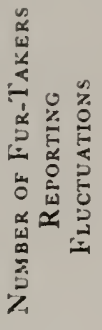 } & ڤั่ & ఏి & $\stackrel{i}{7}$ & $\cong \stackrel{\circ}{=}$ & $\therefore \cong$ & $\stackrel{\infty}{\cong}$ & $\infty+$ & ${ }^{0}=$ & 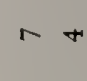 \\
\hline & 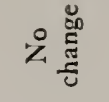 & 39 & $\not i$ & 范 & 3 in & $\bar{F} \infty$ & $\stackrel{\text { ¿ }}{\hat{N}}$ & $\infty \simeq$ & $N r$ \\
\hline & 点总 & $\cong \stackrel{\infty}{\wedge}$ & $\overrightarrow{\text { ते }}$ & in in & $\infty \stackrel{\infty}{\infty}$ & $\infty$ & సి ల & $R$ q & $\approx \sim$ \\
\hline \multirow{2}{*}{ 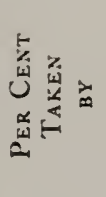 } & 崇总 & 00 & $\widetilde{\sigma} \infty$ & $\Longrightarrow 9$ & ส & 8 ธ & 00 & in f & $\infty \pm$ \\
\hline & 总施 & 88 & ळ్లి స్ల & $\hat{\infty} \infty$ & $\stackrel{\infty}{\sim}$ & F & \& 8 & भे ڤึ & $\alpha \infty$ \\
\hline \multicolumn{2}{|c|}{ 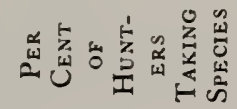 } & $\circ 0$ & $\stackrel{\infty}{\infty}$ & ざ & 听 & $\overrightarrow{6} \overrightarrow{0}$ & 00 & \pm 2 & $m$ \\
\hline \multicolumn{2}{|c|}{ 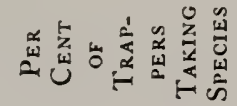 } & $\underset{\infty}{+}$ & $\approx \delta$ & in in & 79 & ה & $\Xi \pm$ & $\infty r$ & 20 \\
\hline \multicolumn{2}{|c|}{ 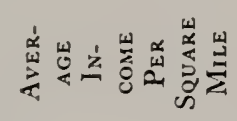 } & 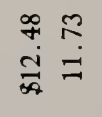 & $\begin{array}{ll}0 & \overrightarrow{0} \\
0 & 0 \\
0 & 0\end{array}$ & 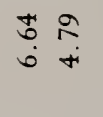 & $\begin{array}{ll}0 & 1 \\
0 & 0 \\
0 & 0\end{array}$ & 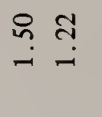 & 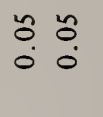 & $\begin{array}{ll}n & 1 \\
0 & 0 \\
0 & 0\end{array}$ & $\frac{2}{0}=$ \\
\hline \multicolumn{2}{|c|}{ 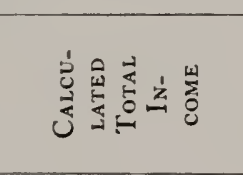 } & 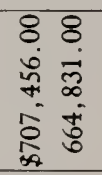 & 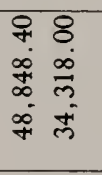 & 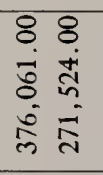 & 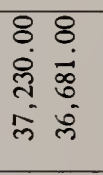 & 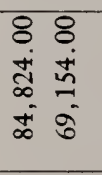 & 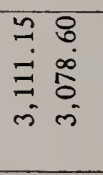 & 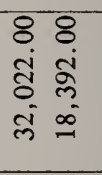 & 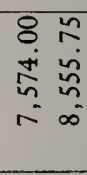 \\
\hline \multicolumn{2}{|c|}{ 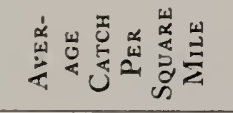 } & $\begin{array}{l}\overrightarrow{6} \\
\dot{n}= \\
=\end{array}$ & ले & $\begin{array}{ll}n & 0 \\
2 & 0 \\
0 & 0\end{array}$ & $\begin{array}{ll}\infty & 4 \\
\infty & 0 \\
0 & 0 \\
0 & 0\end{array}$ & $\begin{array}{ll}2 & 5 \\
0 & 0\end{array}$ & $\begin{array}{l}0 \\
\stackrel{2}{0} \\
0\end{array}$ & $\frac{1}{0} \div$ & $\begin{array}{ll}\infty & 0 \\
0 & 0 \\
0 & 0\end{array}$ \\
\hline \multicolumn{2}{|c|}{ U } & 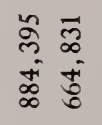 & 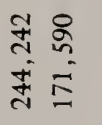 & 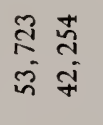 & 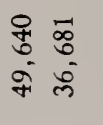 & 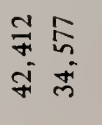 & $\begin{array}{ll}0 & 0 \\
\infty & \stackrel{2}{\circ} \\
\infty & \infty \\
\infty & \infty\end{array}$ & 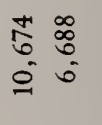 & 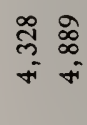 \\
\hline \multicolumn{2}{|c|}{$\begin{array}{l}z \\
0 \\
0 \\
\vdots \\
4 \\
4\end{array}$} & 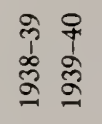 & 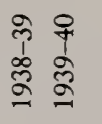 & 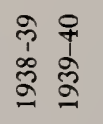 & 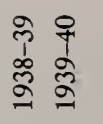 & 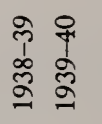 & 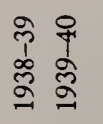 & 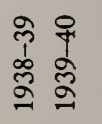 & 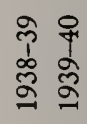 \\
\hline \multicolumn{2}{|c|}{ 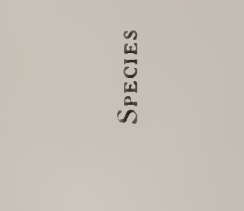 } & 离 & $\begin{array}{l}E \\
\text { E. } \\
0 \\
0 \\
0\end{array}$ & 竞 & $\begin{array}{l}\text { 站 } \\
\text { 站 }\end{array}$ & 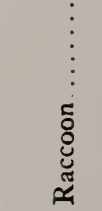 & 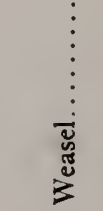 & 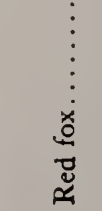 & 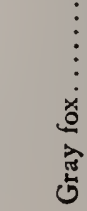 \\
\hline
\end{tabular}


doubtedly below average, because of low raw fur prices.

15. Fur quality, fundamentally influenced by food, injury, age and season, was studied in some detail during the survey, which revealed that about 11 per cent of Illinois furs were damaged, mainly by $\operatorname{dog} s$ and improper handling. Kits, of little value in the fur trade, constituted, for muskrat, 8.5 per cent; opossum, 15 per cent; raccoon, 10 per cent; skunk, t per cent; and mink, 2.5 per cent. The species showing the highest percentage of No. 1 furs were, in descending order, weasel, mink, skunk, raccoon, gray fox, muskrat, red fox and opossum. Foxes were damaged mainly by dogs, and opossums by both dogs and carelessness in handling this low-priced fur. From 0.3 to $t .0$ per cent of the mink pelts had white or "cotton" underfur, and such pelts, size for size, averaged only about one-half the value of normal-colored pelts. Less than 10 per cent of Illinois skunks graded "black" and "star," the most valuable classifications, while about two-thirds graded "narrow stripe" and "broad stripe," the least valuable classifications. Mange was observed on red fox, raccoon, opossum and skunk pelts, and lice infestations were reported in those of mink, but in all cases much less than 1 per cent of the skins or animals were involved.

16. Skill in skinning and stretching pelts was directly proportional to trappers' experience. The best handled pelts came from professional and the poorest handled from inexperienced and boy trappers. The loss due to poor handling is unknown, but probably amounted to at least 10 per cent of the total annual fur income. No adequate market has been developed for fur-animal meat or other by-products.

17. About to per cent of the annual fur catch was shipped directly to large fur houses, 50 per cent was sold to local dealers and 10 per cent was picked up at trappers' residences by traveling buyers. The ultimate selling destination of Illinois furs was St. Louis, Chicago and eastern fur centers. Of +3 dealers interviewed, about 65 per cent preferred to buy dried pelts, 25 per cent freshly skinned but unstretched pelts and the remainder preferred unskinned animals or had no preference. Raw furs were found to be always readily salable. It was found that pelts taken illegally, whether before or after the open season, were usually disposed of; those taken before the season by being held until after the season opened, and those taken after the season by being sold in Illinois before the end of the 10-day period during which raw furs might be legally held, or by being transported to and sold in a neighboring state having a season with a later closing date.

18. The average annual income of over $\$ 1,200,000$ yielded by the fur resource in Illinois was found to be derived practically without management and with no investment except time for harvesting the crop and the small cost of trappers' and hunters' supplies. Practical management measures, correlated with agricultural and other land use, would undoubtedly result in a material increase in the annual income.

\section{1 T E R A T URE C 1 TE D}

Anthony, H. E.

1928. Field book of North American mammals. G. P. Putnam's Sons, New York. 625 pp., illus.

Bailey, Vernon

1936. The red fox in America. Nat. Mag. 28(5) : 269-72, 317.

Bennitt, Rudolf, and Werner O. Nagel

1937. A survey of the resident game and furbearers of Missouri. Mo. Univ. Studies $12(2): 1-215$.

Cory, Charles B.

1912. The mammals of Illinois and Wisconsin. Field Mus. Nat. Hist. Zool. Ser. 153 (11): 1-505. Illus.
Dearborn, Ned

1932. Foods of some predatory fur-bearing animals in Michigan. Mich. Univ. School of Forestry and Cons. Bul. $1: 1-52$. Illus.

Driver, E. C.

1930. The fur yield of Illinois. Unpublished manuscript. III. Nat. Hist. Surv.

Errington, Paul L.

1937a. Management of the red fox in lowa. Am. Wildlife 26(2):2t, 30-1.

1937\%. Drowning as a cause of mortality in muskrats. Jour. Mammal. 18(4):497500 . 
1938. Observations on muskrat damage to corn and other crops in central Iowa. Jour. Ag. Res. $57(6): 415-21$.

1939. Reactions of muskrat populations to drought. Ecol. 20(2) :168-86.

1940. Natural restocking of inuskrat-vacant habitats. Jour. Wildlife Mgt. $f(2)$ : $173-85$

Forbes, Stephen A.

1912. The native animal resources of the state. 111. Acad. Sci. Trans. 5:37-48.

Frison, Theodore $\mathbf{H}$.

1931. State Natural History Survey. III. Blue Book 1931-32:387-400. Illus.

1933. Economic problems of Illinois' fields, forests, and streams solved by Natural History Survey. 11l. Blue Book 1933-34: 477-92. Illus.

Green, Dorr D., and Ermest M. Mills

19+1. The control of skunks. U. S. Fish and Wildlife Serv. Wildlife Leaf. 181. + pp. (Mimeographed.)

Gregory, Tappan

1936. Mammals of the Chicago region. Chicago Acad. Sci. Prog. Act. 7 (2-3) : 12-75. Illus., bibliog.

Hahn, Walter L.

1907. Notes on the mammals of the Kankakee Valley. U. S. Natl. Mus. Proc. $32(1537):$ 455-64.

Hall, E. R.

1936. Mustelid mammals from the Pleistocene of North America with systematic notes on some recent members of the genera Mustela, Taxidea and Mephitis. Carnegie Inst. Wash. Pub. 473: $41-119$. Illus.

\section{Kennicott, Robert}

1855. Catalogue of animals observed in Cook County, Illinois. Ill. State Ag. Soc. Trans. 1: 577-95.

1857. The quadrupeds of Illinois injurious and beneficial to the farmer. U. S. Pat. Off. Rep. Ag. for 1856 , pp. $52-$ 110. Illus.

1858. The quadrupeds of Illinois injurious and beneficial to the farmer. U. S. Pat. Off. Rep. Ag. for 1857 , pp. $72-$ 107.

1859. The quadrupeds of Illinois injurious and beneficial to the farmer. U. S. Pat. Off. Rep. Ag. for 1858, pp. 24156.

Mohr, Carl O.

1937. Illinois trappers' averages reveal coon and possum distribution. Ill. Cons, 2(t):3-t. Illus.

1939. Trappers' reports reveal furbearer fuctuations in Illinois. Ill. Cons. 4 (1) : 4-5. Illus.
1941. Distribution of Illinois mammals. Ill. State Acad. Sci. Trans. 34(2) : 229-32. Illus.

Necker, Walter L., and Donald M. Hatfield

19+1. Mammals of Illinois: an annotated check list with keys and bibliography. Chicago Acad. Sci. Bul. 6(3): 1-60. Illus., bibliog.

Rasmussen, D. I.

1931. Unpublished notes. III. Nat. Hist. Surv.

Sanborn, Colin C.

1925. Mammals of the Chicago area. Field Mus. Nat. Hist. Zool. Leaf. 8. 23 pp. Illus.

Telford, Clarence J.

1926. Third report on a forest survey of Illinois. Nat. Hist. Surv. Bul. 16(1): 1-102. 9 pls., 6 maps.

Thomas, Cyrus

1861. Mammals of Illinois, catalogue. III. State Ag. Soc. Trans. 4(1859-60): 651-61.

U. S. Bureau of Biological Survey

1939. A survey of the annual fur catch of the United States. Wildlife Res. and Mgt. Leaf. BS-140:1-19. (Mimeographed.)

\section{U. S. Fish and Wildlife Service}

1940. The annual fur catch of the United States. U. S. Fish and Wildlife Serv. Wildlife Leaf. 170:1-21. (Mimeographed.)

Vestal, Arthur G.

1931. A preliminary vegetation map of Illinois. Ill. State Acad. Sci. Trans. 23 (3) : 204-17.

Wood, Frank Elmer

1910. A study of the mammals of Champaign County, Illinois. Ill. State Lab. Nat. Hist. Bul. 8(5): 501-613. Illus.

Yeager, Lee E.

1936. Winter daytime dens of opossums. Jour. Mammal. 17(4):410-1.

1942. Coal-stripped land as a mammal habitat, with special reference to fur animals. Am. Midland Nat. 27(3): 613-35. Illus.

$1943 a$. Storing of muskrats and other foods by minks. Jour. Mammal. 24(1): $100-1$

$1943 \mathrm{~b}$. Fur production and management of Illinois drainage ditches. N. Am. Wildlife Conf. Trans. 8. (Not yet issued.)

Yeager, Lee E., and R. G. Rennels

1943. Fur yield and autumn foods of the raccoon in Illinois river bottom lands. Jour. Wildlife Mgt. $7(1)$ :4560. Illus. 